Portland State University

PDXScholar

Spring 5-27-2016

\title{
Relationships that Extend Beyond the Fence-Line: Private Landowner Attitudes and Interest in Conservation Easements
}

Ashley Lyn Vizek

Portland State University

Follow this and additional works at: https://pdxscholar.library.pdx.edu/open_access_etds

Part of the Natural Resources and Conservation Commons Let us know how access to this document benefits you.

Recommended Citation

Vizek, Ashley Lyn, "Relationships that Extend Beyond the Fence-Line: Private Landowner Attitudes and Interest in Conservation Easements" (2016). Dissertations and Theses. Paper 3003.

https://doi.org/10.15760/etd.3004

This Thesis is brought to you for free and open access. It has been accepted for inclusion in Dissertations and Theses by an authorized administrator of PDXScholar. Please contact us if we can make this document more accessible: pdxscholar@pdx.edu. 
Relationships that Extend Beyond the Fence-Line: Private Landowner Attitudes and

Interest in Conservation Easements

by

Ashley Lyn Vizek

A thesis submitted in partial fulfillment of the requirements for the degree of

Master of Science

in

Environmental Science and Management

Thesis Committee:

Max Nielsen-Pincus, Chair

Eugene Foster

Jennifer Morse

Portland State University

2016 
C 2016 Ashley Lyn Vizek 


\begin{abstract}
Private land conservation provides an opportunity to address problems of habitat fragmentation and biodiversity loss caused by an increase in the development and parcelization of private land. Conservation easements (CEs) are an innovative tool used by land trusts to protect significant natural qualities of private land in perpetuity, while also allowing the land to remain in private ownership. Traditionally, property represents an individualistic relationship, however, CEs redefine this relationship by seeking to maximize the overlap in private and public goods in property. In this study, I explore the relationship between the common good and private property through an analysis of landowner attitudes and interest in conveying CEs. To address my research objectives I implemented a mixed-mode survey to 664 private landowners in the Whychus Creek Watershed in Deschutes County, OR. I received 257 survey responses, yielding a response rate of $41 \%$.
\end{abstract}

The first layer of this study focuses on landowner attitudes towards CEs (Chapter 2). The results of an exploratory factor analysis suggest there are two dimensions to landowner attitudes towards CEs_ — an internal and external dimension. I constructed logistic regression models to predict positive internal and external attitudes and found that external attitudes are primarily influenced by environmental beliefs, whereas internal attitudes are influenced by a suite of factors including financial beliefs and perceived risk to private ownership. Furthermore, landowner knowledge and awareness of CEs may play a role in attitude development. I found that as awareness increased the number of landowners perceiving low risk also increased. Additionally, I found that those who learned about CEs from a peer were more likely to have an extreme positive or negative 
attitude towards CEs. The second part of this study focuses on landowner interest in conveying a $\mathrm{CE}$ (Chapter 3). The results of a multinomial logistic regression analysis suggest that positive external and internal attitudes towards CEs provide the foundation for $\mathrm{CE}$, while personal incentives and connections to the social and/or natural community serve as the motivation driving CE conveyance.

Although the results of this study are only representative of landowners in the Whychus Creek Watershed I argue that some of the findings may be more broadly applicable. Contributing to our conceptual understanding of CEs, I discuss how CEs may be beneficial in reintegrating the common good into private property. Further, I highlight that landowner connections to both the social community and natural environment are important characteristics of CE conveyance as well as private land conservation in general. 


\section{DEDICATION}

To all the people and places I call home 


\section{ACKNOWLEDGEMENTS}

Thank you to the landowners in the Whychus Creek Watershed. This study would not have been possible without your thoughtful and insightful responses; thank you for sharing your perspective with me.

I am very grateful to my advisor, Dr. Max Nielsen-Pincus, not only for his expertise as a researcher and scientist, but also for his consistent and effective guidance as a mentor. I appreciate the assistance Max has provided throughout my thesis work. He not only helped me when I was struggling, but more importantly, challenged me to be better. I could not have asked for a better advisor. Max-I am honored to have worked with you these past two years. Thank you for inspiring and supporting my research interests.

Thank you to my committee members, Eugene Foster and Jennifer Morse, for their time and insightful feedback on my thesis. I am fortunate to have connected with Dr. Foster and Dr. Morse through classes I took while at PSU. I appreciated the perspective and passion they brought to teaching and was grateful for their expertise in my thesis work.

My lab has been instrumental in the completion of my thesis (and my sanity as a graduate student). I am so lucky to have had the opportunity to work with the members of the Nielsen-Pincus Lab: Matt DeAngelo, Cody Evers, Sam Hamlin, Tyler Mahone, Erin Upton, Anne Weaver and Sabra Comet. Thank you for your thoughtful feedback, for challenging my ideas, for listening to my presentations, for indulging in conversations about conservation easements, for inspiring me and for making me laugh. 
I would also like to acknowledge the talented staff and faculty in the Department of Environmental Science and Management at PSU. I am grateful to the Department for providing vital financial support through a Teaching Assistantship. Thank you to the Bushby Scholarship Fund and the Nielsen-Pincus Natural Resources Policy and Management Lab for funding my survey.

Before coming to PSU, I had the opportunity to work with two extremely talented and wonderful individuals, Jolie Krasinski and Dennis O'Brien. Thank you for your thoughtful feedback on my research proposal, survey instrument and summary report. More importantly, however, I want to thank you for inspiring my career goals and ambitions as a graduate student.

Thank you to the expert reviewers and select landowners who reviewed my survey including: Laurie Nielsen, Jim Johannsen at Jo Davies Conservation Foundation, Kerry Leigh at the Natural Land Institute, Bruce Hannon and Terre Ziegler at the Land Conservation Foundation, Brad Nye at Deschutes Land Trust, Mike Running at the Coalition of Oregon Land Trusts, Dale Cramer Burr and Allan Olson at the Lower Nehalem Community Trust.

Thank you to my amazingly supportive friends. I would be lost without your encouragement, words of kindness and positive energy. Special thanks to Casey Lewis for working with me to analyze some of my data for a class project. Many thanks to Matt DeAngelo and Jaclyn Teixeira for their support and friendship.

Last but certainly not least, I am beyond grateful for my wonderful family. Without you I would not have accomplished all that I have. Wherever I go I know you will always be there for me, but wherever you are will always be home. 
TABLE OF CONTENTS

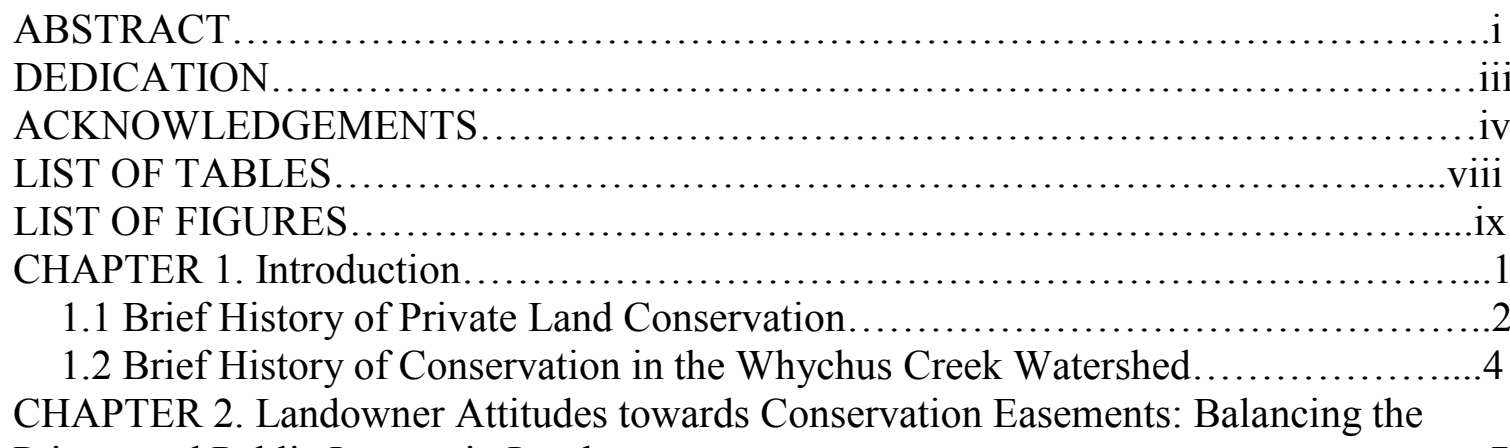

Private and Public Interest in Land.................................................

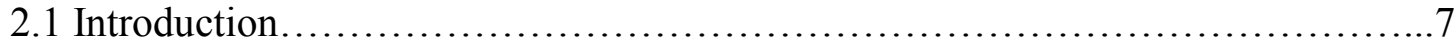

2.1.1 Competing Interests: Dual Interest Theory ........................... 10

2.1.2 Risk and Private Property Concepts.....................................11

2.1.3 Awareness and Peer Exchange........................................14

2.1.4 Research Objectives.................................................... 16

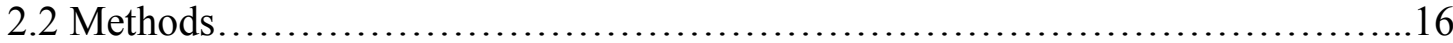

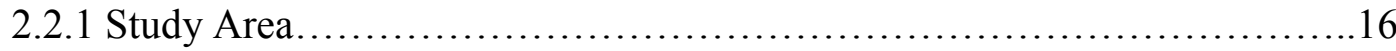

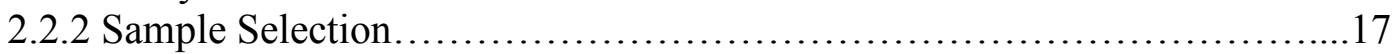

2.2.3 Data Collection........................................................

2.2.4 Data Analysis...........................................................

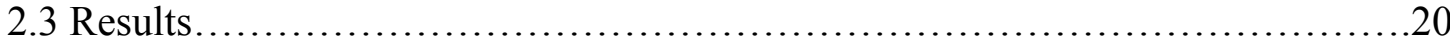

2.3.1 Research Question 1 and 2: Describing Attitude Responses and

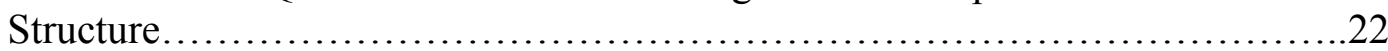

2.3.2 Research Question 3: Predicting Positive Attitudes towards CEs............23

2.3.3 Research Question 4: Relationship between Risk and Awareness...........24

2.3.4 Research Question 5: Predicting CE Attitude Extremity......................25

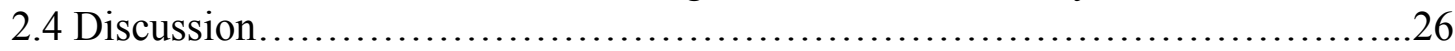

2.4.1 Complexity of Attitudes towards CEs................................26

2.4.2 Property Rights Concepts Disconnect..................................27

2.4.3 Role of Awareness and Information Sources...............................31

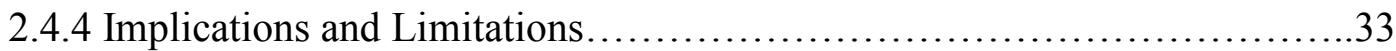

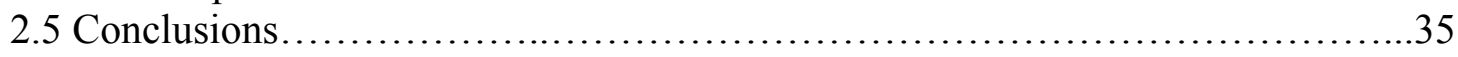

CHAPTER 3. Foundations of Conservation Easement Conveyance: Attitudes and Attachment to the Natural and Social Community....................................36

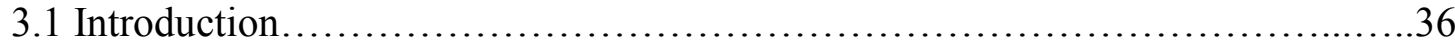

3.1.1 Parcel-Level: Key Components of Individual Behavior......................38

3.1.2 Parcel of the Community: Place Protective Behavior..........................40

3.1.3 Research Objectives....................................................44

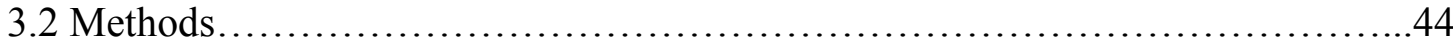

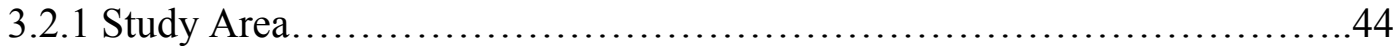

3.2.2 Sample Selection.................................................... 45

3.2.3 Data Collection......................................................46

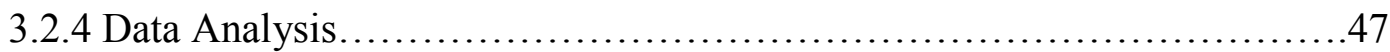

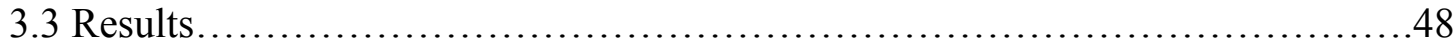




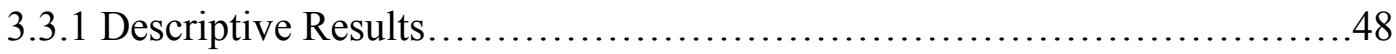

3.3.2 Multinomial Regression Results...................................51

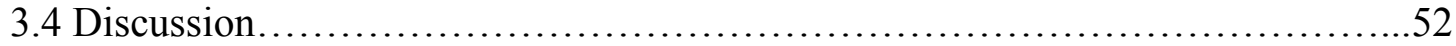

3.4.1 Attitudes: Foundations of CE Conveyance............................52

3.4.2 Connection to Place: Motivations for CE Conveyance......................54

3.5 Conclusions and Limitations......................................................

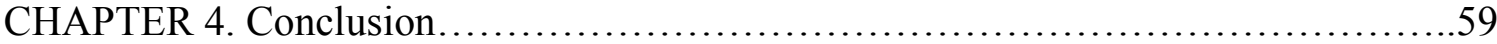

4.1 Strong Internal and External Attitudes as Foundations for CE Conveyance........59

4.2 Personal Incentives and Strong Connections to the Social and/or Natural

Community as Motivations for CE Conveyance.....................................59

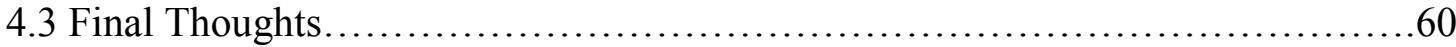

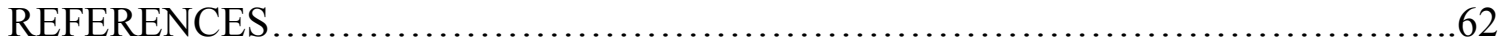

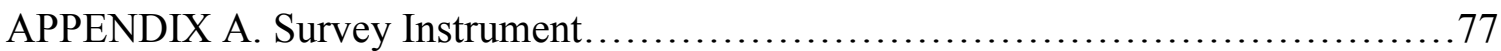

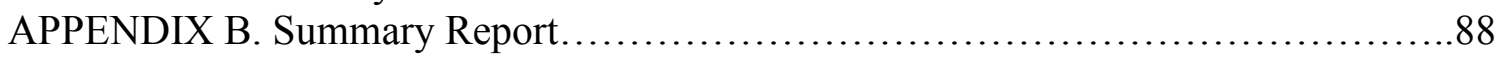

APPENDIX C. Human Subjects Approval...........................................125 


\section{LIST OF TABLES}

2.1 Summary of Items Used in Attitude Logistic Regression........................21

2.2 Descriptive Results and Exploratory Factor Analysis Results of Attitude Items......23

2.3 Positive Attitude Logistic Regression.......................................24

2.4 Contingency Table of Awareness and Perceived Risk to Private Ownership........25

2.5 Summary of Attitude Extremity Logistic Regression...........................25

3.1 Summary of Items Used in Multinomial Logistic Regression Predicting Interest in Conveying CE............................................................ 50

3.2 Summary of Landowner Response to Incentives............................51

3.3 Multinomial Logistic Regression Predicting Interest in Conveying CE.............52 


\section{LIST OF FIGURES}

1.1 Conceptual Diagram of Conservation Easements................................4

1.2 Ownership Map of the Whychus Creek Watershed.................................6 
CHAPTER 1. Introduction

There is a strong culture of individualism in America which is illustrated in the common, though often misleading perception of property. Property is commonly thought of as individual and absolute such that a landowner can do what they want with their land. These ideals have been seared on the landscape as stark boundaries, serving as a symbol to keep others out. Thus, property often functions as an individual parcel separated from the surrounding landscape. Freyfogle (2007), however, argues that this perception of property is actually built upon seven myths of private ownership, among which are the beliefs that property rights are timeless and that regulations interfere with these rights. These beliefs have been brought to the forefront as environmental legislation prompts new land use regulations.

Whether it be through high profile events such as the standoff at Malheur National Wildlife Refuge - the occupation of federal lands during January 2016 by an armed militia — or local nuisance cases, as a society we are very familiar with conflicts regarding private property rights and are constantly arguing about what it means to own property. However, there is another story that is frequently buried by these contentious battles. When asked many might conceptualize property as individual, an expression of freedom, a fundamental American right, but when we look closer we see that people do not always act on this perception. Farmers and ranchers have been found to be influenced by stewardship values, a care for the land that extends beyond the self (Chouinard et al. 2008; Thompson et al. 2014; Kalcic et al. 2014; Jackson-Smith et al. 2005). In relation to land stewardship, Drescher (2014) describes the strong connections that rural landowners 
form with their land and its natural environment, a meaning of property that encompasses more than self-interested freedoms. Place attachment has been well-documented in the literature and has been linked to place protective behavior (Vaske and Kobrin 2001; Nielsen-Pincus et al. 2010; Lokocz et al. 2011; Erickson et al. 2002; Norton and Hannon 1997).

The objective of my thesis is to explore the relationship between the public good and private property through an analysis of landowner attitudes and interest in private land conservation, specifically conservation easements (CEs). CEs are an effective platform to explore ideas about private and public values in property as they represent private actions that serve a public good, challenging the traditional individualistic understanding of property. My thesis is also more broadly about individual connections to land and community, connections which may drive not only effective private land conservation but a reintegration of the common good into private property. Rather than focusing on areas struggling with deep-seated property rights conflicts, this study seeks to highlight a place —Whychus Creek Watershed in Deschutes County, Oregon—where there has been effective private land conservation.

\subsection{Brief History of Private Land Conservation}

Alongside the approval of monumental environmental legislation such as the Clean Air Act, Clean Water Act and the Endangered Species Act, an increased interest in private land conservation developed (Bray 2005). Land trusts, as defined by the Land Trust Alliance, are organizations that work to conserve land. Some land trusts, such as 
The Nature Conservancy, are large national or international organizations while other land trusts are small and locally based. As part of the broader environmental movement of the 1960s and 1970s, but also due to changes in the tax code, the number of land trusts conserving private land has grown exponentially (Bray 2005). The primary method by which land trusts conserve land is through CEs. A CE is an individually-crafted legal agreement between a landowner and an eligible organization, such as a land trust or government agency. CEs can be described within the context of the classic metaphor of property as a "bundle of sticks" wherein each stick represents a right. CEs allow for some of the landowner's rights to be separated from the bundle and voluntarily sold or donated. When a landowner decides to place a $\mathrm{CE}$ on their property they continue to own the property but the uses and/or management practices that would negatively affect the conservation values are limited and/or prohibited.

In some cases, land trusts and CEs provide a locally-driven alternative to land use regulations. Similar to regulations, CEs serve the public good, however, CEs also acknowledge the individual nature of property, maximizing the overlap in the public and private values in property (Figure 1.1). Morrisette (2001) describes CEs as an approach which "encourages private action in pursuit of a public good in addition to, or apart from, the government's protection of the environment" (p. 377). The literature on how CEs relate to property notions, however, is inconclusive. Rissman (2013) argues that as landowners are often compensated for a $\mathrm{CE}$ —either through direct payment for the purchase of a $\mathrm{CE}$ or through tax incentives for the donation of a $\mathrm{CE}-\mathrm{CEs}$, similar to payments for ecosystem services, further strengthen the disproportionate focus on 
property rights over duties or responsibilities. In contrast, Hurley et al. (2002) stated that CEs reflect "ecosystem management principles of transcending jurisdictional and institutional boundaries" (p.304). Thus, a better understanding of landowner attitudes and interest in CEs may help inform how CEs interact with property perspectives and the broader social landscape.

\section{Conservation Easements}

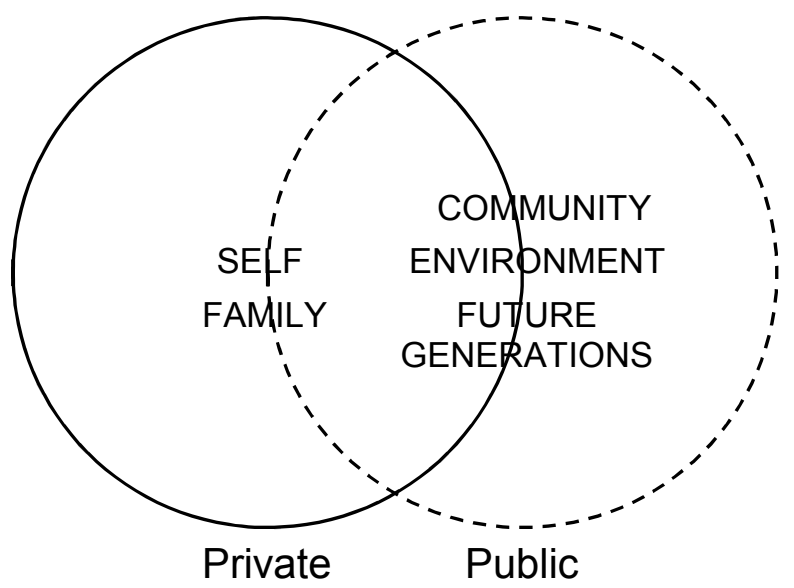

Figure 1.1 Conceptual diagram of conservation easements as maximizing the overlap in private and public values in property. Deciding to convey a CE involves considering both self-interested and other-interested (i.e. community, environment, future generations) benefits and consequences.

\subsection{Brief History of Conservation in the Whychus Creek Watershed}

Whychus Creek provides water for local residents and farmers and has historically provided aquatic habitat for species such as the steelhead trout—listed as threatened under the Endangered Species Act (ESA; Dengel 2014). Prior to 1999, overallocation of water rights caused Whychus Creek to run dry during late summer and early fall, creating water availability issues for the community and subsequently motivating interest in streamflow and habitat restoration. Despite the extirpation of many native fish species that once inhabited Whychus Creek due to the development of dams within the 
larger Deschutes River Basin, regulation under the ESA has further motivated restoration efforts in the Watershed to create and enhance suitable fish habitat. Throughout the last two decades, the community within the Whychus Creek Watershed has worked to balance the water needs of irrigation and municipal uses as well as instream usesprimarily fish habitat. Due to these efforts, stream flow during late summer and early fall has steadily increased. However, temperature pollution is still a concern, and in 2011 the Oregon Department of Environmental Quality initiated development of a TMDL (required under the Clean Water Act for 303(d) listed waterbodies) for the Upper Deschutes and Little Deschutes Sub-basins (which includes Whychus Creek) (ODEQ 2008). The TMDL development process is still underway in 2016, further motivating conservation and restoration efforts in the Whychus Creek Watershed.

The Whychus Creek Watershed is an inspiring example of collaborative restoration and conservation - illustrated by the pattern that emerges in an ownership map of the Watershed (Figure 1.2). Along lower Whychus Creek, which is predominantly privately-owned, Deschutes Land Trust has conserved a substantial amount of land through fee-simple and conservation easement acquisition. Founded in 1995 the Deschutes Land Trust (DLT) is an accredited land trust (certification provided by the Land Trust Alliance ensuring organizations meet national standards for excellence) striving to "work cooperatively with landowners to conserve land for wildlife, scenic views and local communities" (www.deschuteslandtrust.org). DLT has conserved 8,750 acres-2,200 of which surround Whychus Creek. This contiguous string of conserved 
land speaks to the commitment of the community within the Watershed to the natural environment, which has been cultivated and strengthened over time.

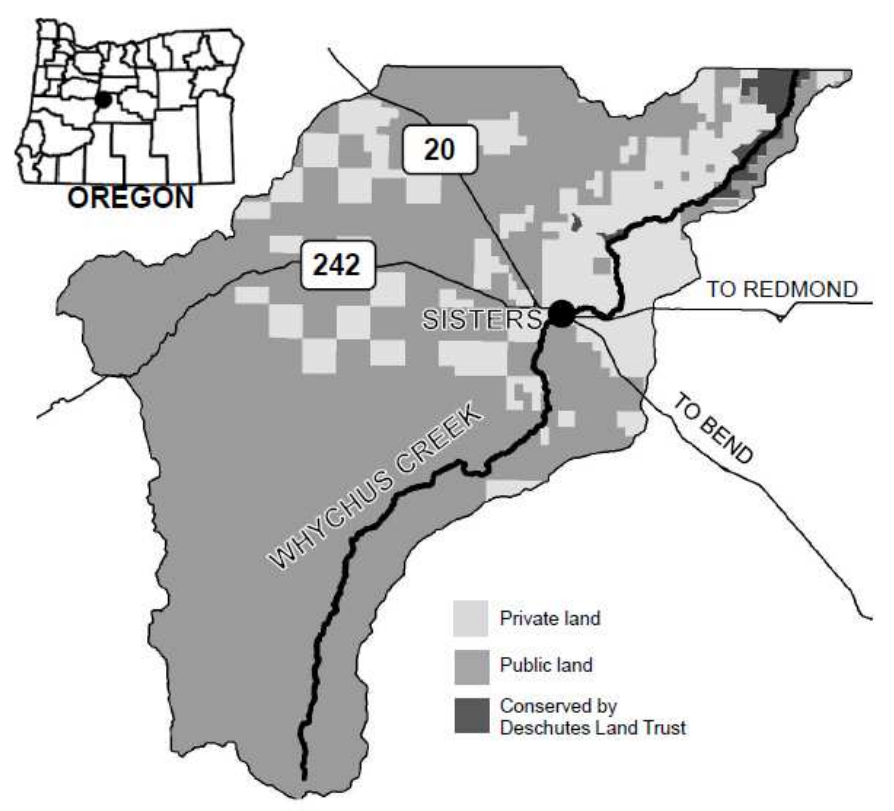

Figure 1.2 Ownership map of the Whychus Creek Watershed. Lower Whychus Creek is predominantly privately owned (light gray) and is surrounded by public protected land (medium gray). There has been a substantial amount of conservation along the creek (land owned/held by Deschutes Land Trust in dark gray). 
CHAPTER 2. Landowner Attitudes towards Conservation Easements: Balancing the Private and Public Interest in Land

\subsection{Introduction}

Land protection in the United States has historically been accomplished through the outright acquisition of land by public agencies; however, these reserves may not protect the land with the greatest biodiversity (Scott et al. 2001). A portion of the preferred habitat for $90-95 \%$ of federally threatened and endangered species is on private land (Wilcove et al. 1996). Despite the ecological importance of private land, there has been a dramatic increase in the development of private land (Brown et al. 2005). Rural and low-density communities near natural areas have become an appealing option for development as people seek quality-of-life and outdoor recreational opportunities (Maestas et al. 2001), presenting an urgency to incorporate private lands in natural area conservation.

Conservation easements (CEs), although not a new idea, emerged in the 1980 s as an innovative method of protecting private land. Now, CEs are the primary tool used by land trusts (non-profit organizations that actively work to conserve land) to protect habitat, biodiversity and open space (Kiesecker et al. 2007). CEs can be described within the context of the classic metaphor of property as a "bundle of sticks" wherein each stick represents a right. CEs allow for some of the landowner's rights to be separated from the bundle and voluntarily sold or donated. When a landowner decides to place a CE on their property they continue to own the property but the uses and/or management practices that would negatively affect the conservation values are limited or prohibited. For example, 
future development and subdivision of the land is frequently prohibited under a CE. Further, a CE represents an individually-crafted legal agreement between a landowner and the easement holder (i.e. land trust or government agency), designed to maximize both public and private interests in a property. CEs are attached to the property deed, meaning that significant conservation values of a piece of land can be permanently protected.

Private land conservation through the use of CEs has grown rapidly over the last two decades as the number of land trusts has increased from about 600 in the 1980s to 1,723 in 2010 (Chang 2011). According to the most recent Land Trust Census, local and state land trusts hold 8.8 million acres of CEs and own 2.1 million acres outright (Chang 2011), a large increase from the 450,000 acres held by local and state land trusts in 1990 (Bray 2005). In an effort to keep up with the persistent expansion of CEs, Merenlender et al. (2004) called for, among other things, a better understanding of the organizations implementing CEs and landowners' interest in CEs stating that "we know little about which characteristics of easements and the institutions that hold them are attractive to landowners...” (p. 71). Landowner motivations for placing a CE on their property has now become a more common focus in the literature, yet is still lacking in extent and depth as the majority of studies are specific to agricultural landowners or landowners who have already placed a CE on their property (Miller et al. 2010; Greiner 2015).

While past research has identified influential motivations for CE adoption such as place attachment, environmental reasons and financial incentives (Ernst and Wallace 2008; Cross et al. 2011), little is known about landowner attitudes towards CEs. Attitudes 
differ from motivations in that attitudes are the evaluation of a behavior, whereas, motivations are the force that drives a person to enact in that behavior. According to the theory of planned behavior (TPB), attitudes are an important determinant of behavior (Ajzen 1991). The TPB is a commonly used theoretical framework for predicting human behavior and has been extensively utilized throughout research on natural resource management (Price and Leviston 2014; Van Gossum et al. 2005; Primmer et al. 2010). The TPB states that behavior follows directly from behavioral intention, which is influenced by attitudes towards the behavior, perceived behavioral control and subjective norms. Nowak (2012) and Brain et al. (2014), among the few studies that apply the TPB to CEs, found that attitudes and subjective norms were significant predictors of landowner intention to adopt a CE. As attitudes may play a vital role in CE adoption, it is important to continue to expand our understanding of landowner attitudes towards CEs and the components that influence these attitudes. The following sections introduce issues that have been found to impact landowner conveyance of CEs, which may also be central to landowner attitudes towards CEs. Although past research has discussed the importance of these factors, they have not been analyzed together. This study builds upon past research highlighting the importance of 1) competing interests in land management decisions, 2) private property owner attitudes towards private land conservation and 3) awareness as a limiting factor to CE adoption. 


\subsubsection{Competing Interests: Dual Interest Theory}

Private landowners' decisions to place a CE on their property requires multiple layers and scales of analysis - landowners are evaluating both the impacts to the current private and public values of their property and the impacts to future uses and values. Depending on the situation, CEs may reduce and/or enhance certain property values; thus, landowners are faced with a challenging evaluation of the financial, personal and environmental trade-offs associated with placing a CE on their property. Chouinard et al. (2008) explore the trade-offs farmers face in farm practice selection suggesting that a farmer has at least two dimensions to their utility, an "ego-utility" and social or "stewardly" dimension. These trade-offs are more broadly addressed in dual interest theory (Lynne 1999; Czap et al. 2012). Dual interest theory acknowledges the coexistence of both self-interest and shared-interest behavioral tendencies (Czap et al. 2012). Thompson et al. (2014) utilize Dual Interest Theory to conceptualize farmers' views of the environment as two distinct factors, "stewardship" and "production," demonstrated through an exploratory factor analysis. Similar, to agricultural landowners considering best management practices, landowners considering a CE may also be trying to balance their own self-interests with a shared-interest in conserving a public good.

Though not explicitly represented in a dual interest framework, these are not new ideas in the CE literature. Farmer et al. (2011) identified nine motivational categories (representing both self- and shared-interests) for CE adoption, including community, culture, environmental, family heritage or legacy, financial incentives, open space protection, place attachment, societal factors and witnessing land development. Further, it 
has been recognized that landowners may experience competing motivations to place a $\mathrm{CE}$ on their property, such as a strong place identity and conservation ethic as well as a motivation to avoid restrictions on their land (Cross et al. 2011; Farmer et al. 2011). Ernst and Wallace (2008) surveyed landowners who had participated in CEs and found that landowners were motivated more by natural resource protection and community goals than by financial incentives or family/estate matters, suggesting the important role of shared-interests in CE adoption. Although environmental or social motivations are often found to be the primary motivating factor for CE adoption, self-interests such as financial incentives should not be dismissed. Rather, financial incentives provide a means for realizing both self- and shared-interests (Ernst and Wallace 2008). As both self- and shared-interests are central to landowner adoption of CEs, a dual interest framework may also be useful in conceptualizing landowner attitudes towards CEs and highlighting the competing interests that may be shaping these attitudes.

\subsubsection{Risk and Private Property Concepts}

CEs challenge traditional perspectives on private property rights by integrating public and private interests in private land, thus landowners may believe that this integration of rights presents a risk to their ownership of the land. Among other potential risks associated with $\mathrm{CE}$ adoption, such as social conflict and regulation risks, landowners' perceived risk of CEs infringing upon private property rights is likely to impact their attitudes towards CEs. The perceived risk to private property rights may be impacted by landowners' attitudes towards CEs as well as their perspectives on private 
property rights. Kabii and Horwitz (2006) hypothesized that landowners with strong private property rights notions will be less likely to adopt a CE, whereas, Nowak (2012) found that this relationship is mediated by attitudes towards CEs.

In order to understand how CEs relate to concepts of private property rights, it is necessary to provide a brief discussion of the foundations of property in the U.S. The concept of property is elusive and has been debated for hundreds of years. Aristotle thought of property as a "natural right" where private property encouraged the virtue of liberality (Bell and Parchomovsky 2005). Building upon the idea of a natural right in property, John Locke's labor theory associates ownership with labor exerted upon an object. Further, the Lockean theory of property is based on the view that objects are beneficial only in private ownership (Bell and Parchomovsky 2005). During the $19^{\text {th }}$ century, William Blackstone developed an understanding of property as individual and absolute entitlements (Bell and Parchomovsky 2005). Freyfogle (2003) paints a picture of post-Revolution America integrating both old ideas of feudal hierarchy and new individualistic understandings of property, arguing that it was not until the rise of industrialism that private property rights began to disintegrate from the larger public sphere. In the $20^{\text {th }}$ century, the absolute and individualistic concept of property was replaced with Hohfeld's "bundle of rights" metaphor which transformed property rights into an aggregation of rights, duties, powers and privileges (Bell and Parchomovsky 2005). However, rather than diverging from historical theories of property, some argue that the dominant paradigm of property as a bundle of rights perpetuates an individualistic perspective of private property grounded in a "cultural myth about the 
supremacy of private property," (Duncan 2005, p. 786). More specifically, Duncan (2005) states that the bundle of rights metaphor has come to focus on individual parts, disregarding interactions with the surrounding landscape and broader society.

Despite deep values built upon absolute and individual property ownership the law does not always support these values. The doctrine of nuisance (or the do-no-harm principle) explicitly imposes restrictions on property rights that negatively impact others, acknowledging the interconnectedness of land and ownership (Duncan 2005).

Furthermore, as public interests and values have changed so have the legal institutions governing property rights. Environmental legislation recognizes the social value in air, water and wildlife habitat, placing a public interest in these resources. However, property is argued to be not only a legal concept, but also a dynamic social process (Yung and Belsky 2007). In some cases, property as a social institution has diverged from the legal interpretation of property leading to strong opposition to changing public policies, especially in relation to increased regulation on private land. Although culturally we may encourage an individualistic notion of property, individual perspectives on private property rights are complex and not all landowners can be characterized by the traditional perspective on property. Jackson-Smith et al. (2005) found that ranchers reported diverse beliefs about private property rights suggesting that there is more than one perspective of private property. Though the majority of ranchers believed individual property rights include the right to exclusively use the natural resources on the land, the majority also believed that these rights are subject to the rights of others, especially their neighbors and to a lesser extent society, which reflects threads of the doctrine of nuisance (Jackson- 
Smith et al. 2005). Additionally, Yung and Belsky (2007) highlight that ranchers on the Rocky Mountain Front incorporated both self- and community-interests in their conceptualizations of private property. Analysis of private property rights perspectives in connection with underlying dual interests may expand our understanding of potential barriers to CE adoption.

\subsubsection{Awareness and Peer Exchange}

At the landscape-scale we have witnessed a dramatic growth in the use of CEs by land trusts; however, at the local or regional-scale the acceptance of CEs may not be as apparent. In Oregon, for instance, CEs are not as commonly implemented-nationally Oregon ranks $40^{\text {th }}$ in the number of CEs (Paulus and Orizola 2015). The lack of information about private land conservation options and financing strategies has been proposed, among other economic factors, as a potential reason for low enrollment in conservation programs (Van Fleet et al. 2012; Ma et al. 2012). Van Fleet et al. (2012) found, in a survey of randomly selected forest owners, about half of respondents reported "not heard of" or "knowing nothing" about estate planning, CEs, and current use property tax reductions. Additionally, the majority of respondents reported little first- or secondhand experience with CEs (90\%), estate planning (84\%), and current use property tax reductions (75\%). Kittredge et al. (2015) suggest that knowledge and training related to conservation practices can influence beliefs and behavior, calling for future research to explore the link between conservation awareness and behavior. 
In addition to its influence on attitudes in general, awareness may also play a role in attitude strength. Bright and Manfredo (1997) found that attitudes towards issues that are highly relevant become more extreme with increasing information. However, increasing information alone may not be sufficient to explain attitude extremity. The psychology literature has explored the relationship between discussion networks and attitude extremity building upon the effect of group polarization (Moscovici and Zavalloni 1969). Attitude extremity has been described as a dimension of attitude strength and thus attitude durability (Petty and Krosnick 1995). Group polarization explains that repeated expressions of an individual's own opinion and exposure to others' opinions involving social comparison and persuasion results in attitude polarization. Further, discussions with like-minded peers was found to be significantly related to attitude extremity, whereas, discussion with non-like-minded peers was unrelated to attitude extremity (Binder 2009). This relates to the recent interest in peer exchange within natural resource management. Peer exchange involves the transfer of ideas and information between peers and has been found to contribute to how private landowners manage their land. Many programs across the U.S. have been designed to foster peer exchange, including at least 39 state-level Extension Forestry programs targeting private forest owners (Kueper et al. 2014). The understanding of the relationship between awareness and attitudes towards CEs has substantial practical implications that can help guide the effective distribution of information about CEs. 


\subsubsection{Research Objectives}

Through this research study I aim to contribute to the conceptual understanding of CEs and private landowners' evaluation of CEs, while also providing a practical perspective on attitudinal influences. More specifically the research questions guiding this project include:

1. What are landowners' attitudes towards CEs?

2. Does the structure of $\mathrm{CE}$ attitudes reflect competing interests?

3. How do CE familiarity, $\mathrm{CE}$ beliefs, $\mathrm{CE}$ risk perceptions and land management goals relate to landowners' attitudes towards CEs?

4. How does awareness of CEs relate to perceived risk?

5. How does awareness and sources of information influence attitude extremity?

\subsection{Methods}

\subsubsection{Study Area}

The Whychus Creek Watershed (Deschutes County, OR) provided an interesting study area to investigate my research questions. Deschutes County has been experiencing increases in population and is one of the fastest growing counties in Oregon. Private land conservation is especially important along lower Whychus Creek as it is predominantly privately owned (Figure 1.2) and vulnerable to increases in development as the area provides attractive outdoor recreational opportunities and quality-of-life resources. Whychus Creek is a valued ecological, scenic and cultural resource and has been the target of conservation and restoration efforts for 30 years. Interest in restoring Whychus 
Creek gained momentum in the 1990s when many private and public entities began collaborating to restore aquatic and terrestrial habitat in order to address water allocation issues and potential federal regulation under the Endangered Species Act (ESA). Due to these efforts, stream flow during late summer and early fall has steadily increased. However, temperature pollution is still a concern, and in 2011 the Oregon Department of Environmental Quality (DEQ) initiated development of a TMDL (required under the Clean Water Act for 303(d) listed waterbodies) for the Upper Deschutes and Little Deschutes Sub-basins (which include Whychus Creek) (ODEQ 2008). As of 2016, the TMDL development process and efforts to reintroduce the ESA-listed Middle Columbia River steelhead are still underway, further motivating conservation and restoration efforts in the Whychus Creek Watershed.

\subsubsection{Sample Selection}

The target population for this study consisted of private landowners owning five acres or more within the Whychus Creek Watershed. Private landowners who owned property directly adjacent to Whychus Creek or to property protected by Deschutes Land Trust were also included regardless of the five-acre minimum criteria-although these exceptions may contain small acreage properties, they have potential to create substantial impacts on conservation within the watershed due to their location. Based on these criteria I used ESRI ArcMap software to create a sample frame from Deschutes County 2014 GIS taxlot data. After removal of all ineligible units the target population consisted of 756 landowners. Following suggestions from Dillman (2000), I determined that a 
sample size of 255 would be necessary to represent the population. Assuming a $40 \%$ response rate and 5\% undeliverable rate, I selected a random recruitment sample of 664 landowners.

\subsubsection{Data Collection}

During August and September 2015, I implemented a mixed-mode survey based on the Tailored Design Method (Dillman 2000). The selected sample of 664 landowners were mailed an introductory postcard that included a link to the online version of the questionnaire (day 1). Landowners were then mailed a large manila envelope containing the survey packet (day 9). Following the mailing of the survey packet I sent landowners a postcard, thanking those who had already responded and reminding those who had not completed the questionnaire to please do so (day 17). Lastly, I sent all landowners who had not responded a second packet of survey materials (day 35).

The questionnaire included 38 questions organized into six sections; the majority of the questions used a 5-point Likert-style response scale. The items utilized in this study are summarized in Table 2.2. Attitude and belief items were measured on a 5-point bipolar Likert-scale from "Strongly Agree" to "Strongly Disagree" based on past research studies (Greiner 2015; Balram and Dragićević 2005). Questions designed to measure familiarity with CEs were adapted from the Conservation Awareness Index (Van Fleet et al. 2012). Risk items were measured on a 5-point bipolar Likert-scale from "Very High" to "Very Low." Landowner management goals were measured on a 5-point unipolar scale from "Not Important" to "Very Important." Information source items included several 
different types of questions which included 1) the source from which landowners first learned about a CE, 2) indirect and direct interactions with neighbors (adapted from Schubert and Mayer 2012) and 3) conservation behaviors. The survey instrument was reviewed by experts (land conservation professionals, including Deschutes Land Trust staff, and individuals in academia) and a purposively selected group of landowners.

\subsubsection{Data Analysis}

I used exploratory factor analysis (EFA) to 1) explore the structure of CE attitudes and 2) create response variables for regression analysis. The major assumptions of EFA include a large sample size (Kaiser-Meyer-Olkin index), multivariate normality and sufficient correlations among the data (Barlett test of sphericity). As Likert-style survey data cannot meet the assumption of multivariate normality, it is important to note the risk of instability in the parameter estimates. Despite this, EFA is frequently used with survey data and I think it is a useful tool to gain a better understanding of the underlying dimensions of CE attitudes. Factor selection was based on a scree test and parallel analysis and estimated using a maximum likelihood approach with a "varimax" rotation. I evaluated the internal validity of the factors using Cronbach's alpha and evaluated the fit of the model using a $\mathrm{Chi}^{2}$ test.

I then utilized logistic regression to 1) understand what variables were important in relation to positive attitudes towards CEs and 2) what variables were important in relation to CE attitude extremity. For both of these purposes I followed a similar process. I built full regression models and then constructed a reduced model by removing the 
variables that increased the Aikake Information Criterion (AIC) using a backward stepwise approach. I assessed all models for potential multi-collinearity issues by comparing correlations between the independent variables and calculating the Variance Inflation Factor (VIF). I analyzed how well each model fit the data by calculating the $\mathrm{Chi}^{2} \mathrm{p}$-value of the deviance of the residuals. The Nagelkerke $\mathrm{R}^{2}$ value was calculated to further evaluate the model fit compared to a null model. I utilized an ANOVA to compare the full logistic model to the reduced logistic model. To evaluate the importance of the variables in the model, variable coefficients were converted to odds ratios. Lastly, I used a contingency table to analyze the relationship between awareness and private ownership risk. I used a $\mathrm{Chi}^{2}$ test to evaluate the significance of the relationship. All statistical analyses were performed in " $\mathrm{R}$ " version 3.0.2.

\subsection{Results}

I received 257 responses to the survey, yielding a response rate of $41 \%$. The majority of survey respondents were older than 50 years of age and, in comparison to the general population in the Whychus Creek Watershed (US Census 2013), had a higher level of education and above-average income. Most survey respondents specified that they use their property as a primary residence and live on their property more than nine months out of the year. There was a wide range of property sizes, ranging from less than one acre to greater than 2,000 acres. Despite this, more than $90 \%$ of respondents thought protection of open space and scenic values were important to their land management decisions. 
Survey respondents were moderately aware of CEs; over $60 \%$ of respondents said they knew at least a little about CEs (Table 2.1). Six percent of respondents reported completing a $\mathrm{CE}$ and $11 \%$ had considered a $\mathrm{CE}$, while $31 \%$ knew someone who had completed a CE and 7\% knew someone who had considered a CE. Thirty-three percent of respondents reported learning about CEs from a non-profit organization (land trusts, watershed council or environmental organization) while $8 \%$ learned about CEs from a peer source (spouse, relative or neighbor). Sixty percent of respondents knew of a local land trust and listed an accurate name. In general, survey respondents held positive beliefs about the characteristics of CEs. However, the majority of respondents were unsure if CEs provide adequate financial incentives.

Table 2.1 Summary of items used in attitude logistic regression. Note that some items were averaged for use in logistic regression models due to high correlations and conceptual consistency.

\begin{tabular}{lcccc}
\hline Variables & Scale & Mean & SD & N \\
\hline AWARENESS & & & & \\
Personal Experience & $0-2$ & 0.33 & 0.58 & 258 \\
Indirect Experience & $0-2$ & 1.00 & 0.95 & 248 \\
Land Trust Familiarity & $0 / 1$ & 0.60 & 0.49 & 250 \\
Awareness Index & $0-4$ & 1.93 & 1.29 & 249 \\
$\quad$ Limit uses of property that negatively impact conservation & $0-4$ & 2.37 & 1.46 & 249 \\
$\quad$ values & & & & \\
$\quad$ Are completely voluntary & $0-4$ & 2.19 & 1.56 & 245 \\
$\quad$ Keep land in private ownership & $0-4$ & 2.15 & 1.52 & 246 \\
$\quad$ Can be applied to the entire property or a portion of it & $0-4$ & 1.93 & 1.49 & 249 \\
$\quad$ May provide a financial benefit & $0-4$ & 1.38 & 1.52 & 248 \\
$\quad$ Give the right to monitor and enforce property restrictions to an & $0-4$ & 1.78 & 1.42 & 248 \\
$\quad$ eligible entity & & & & \\
$\quad$ Do not require public access & $0-4$ & 1.67 & 1.47 & 246 \\
BELIEF & & & & \\
Environmental Belief Index & $0-4$ & 3.08 & 0.83 & 246 \\
$\quad$ Protect fish and wildlife habitat & $0-4$ & 3.14 & 0.79 & 245 \\
$\quad$ Protect land from development & $0-4$ & 3.06 & 0.89 & 245 \\
$\quad$ Protect open space and scenic values of the lands they are & $0-4$ & 3.06 & 0.84 & 246 \\
$\quad$ placed on & & & & \\
$\quad$ Protect and/or enhance stream quality & $0-4$ & 3.07 & 0.83 & 245 \\
Financial Beliefs: Provide adequate financial incentives & $0-4$ & 2.31 & 0.83 & 245 \\
$\quad$ RISK & & & & \\
Regulation Risk: Future regulatory burdens & $0-4$ & 2.26 & 1.02 & 243 \\
\hline
\end{tabular}




\begin{tabular}{lllll}
\hline Social Risk: Creating issues with neighboring landowners & $0-4$ & 1.90 & 1.00 & 243 \\
Private Ownership Risk: Reducing amount of land in private & $0-4$ & 1.75 & 1.10 & 242 \\
ownership & & & & \\
MANAGEMENT GOALS & & & & \\
$\begin{array}{l}\text { Development Protection: Protecting my property from development } \\
\text { Habitat Protection: Protection from fish and wildlife }\end{array}$ & $0-4$ & 2.94 & 1.29 & 246 \\
$\begin{array}{l}\text { Recreation: Providing recreational opportunities for me and my } \\
\text { family }\end{array}$ & $0-4$ & 3.00 & 1.04 & 246 \\
Income: Providing an income for me and my family & & 2.75 & 1.16 & 246 \\
INFORMATION SOURCE & $0-4$ & 1.71 & 1.36 & 245 \\
Indirect Neighbor Interaction: Take note of how neighbor manages & $0-4$ & 2.47 & 1.01 & 255 \\
land & & & & \\
$\begin{array}{l}\text { Direct Neighbor Interaction: Talk to neighbor about future plans for } \\
\text { your land }\end{array}$ & $0-4$ & 0.84 & 1.07 & 246 \\
CE Info Source: Peer & $0 / 1$ & 0.08 & 0.28 & 253 \\
CE Infor Source: NGO & $0 / 1$ & 0.34 & 0.47 & 253 \\
Conservation Behavior Index & $0-6$ & 1.04 & 1.74 & 248 \\
$\quad$ Work with an organization to restore land & $0-6$ & 0.20 & 0.71 & 246 \\
$\quad$ Volunteer with a land trust & $0-6$ & 0.28 & 0.81 & 245 \\
$\quad$ Steward or care for protected natural areas & $0-6$ & 0.57 & 1.05 & 244 \\
\hline
\end{tabular}

\subsubsection{Conservation Easement Attitude Responses and Structure (Question 1-2)}

In order to address my first research question, I considered landowner responses to the attitudinal items in the survey (Table 2.2). Most survey respondents expressed neutral attitudes towards CEs, however, at least one third of respondents agreed that CEs are 1) good for fish and wildlife habitat and 2) useful to protect my land from development. The results of the EFA illustrate that the six attitudinal items loaded well on two factors, which I describe as "external" and "internal" (Table 2.2). The "external" attitude is comprised of CE outcomes which represent a public good. The "internal" attitude is comprised of $\mathrm{CE}$ outcomes which represent the personal impacts of a $\mathrm{CE}$. The results of the EFA guided the construction of two attitude response variables used in the following logistic regression models. Items within the external attitude were averaged to form an external attitude index. This was also done for the internal attitude items. The 
average external attitude index was 0.27 with a standard deviation of 0.90 , while the average internal attitude index was 0.00 with a standard deviation of 0.74 .

Table 2.2 Descriptive results of responses to items designed to measure attitude towards CE adoption. Factor loadings of exploratory factor analysis and Cronbach's alpha for each factor containing items bolded items. $\mathrm{Chi}^{2}$ test: $\mathrm{H}_{0}$ of perfect fit cannot be rejected (4.27, $4 \mathrm{df}$, p-value=0.371). Kaiser-Meyer-Olkin measure of sampling adequacy (0.70). Barlett's test of sphericity: significant. Cumulative variance: 0.30 for external and 0.53 for internal factor.

\begin{tabular}{|c|c|c|c|c|c|c|c|c|c|}
\hline & \multicolumn{3}{|c|}{ Placing a $C E$ on my property would be } & \multicolumn{3}{|c|}{ Survey Responses } & \multicolumn{2}{|c|}{ Factor Loadings } & \multirow[b]{2}{*}{$\mathrm{n}$} \\
\hline & & $\begin{array}{c}\text { Strongly } \\
\text { Agree }\end{array}$ & Agree & $\begin{array}{c}\text { Neither Agree } \\
\text { nor Disagree }\end{array}$ & Disagree & $\begin{array}{l}\text { Strongly } \\
\text { Disagree }\end{array}$ & $\begin{array}{c}\text { External } \\
(0.81)\end{array}$ & $\begin{array}{c}\text { Internal } \\
(0.70)\end{array}$ & \\
\hline \multirow{3}{*}{ لَّ } & $\begin{array}{l}\text { Good for fish and } \\
\text { wildlife habitat }\end{array}$ & $18 \%$ & $33 \%$ & $28 \%$ & $14 \%$ & $7 \%$ & 0.75 & -0.074 & 244 \\
\hline & $\begin{array}{l}\text { Useful to protect my } \\
\text { land from }\end{array}$ & $11 \%$ & $33 \%$ & $32 \%$ & $16 \%$ & $8 \%$ & 0.77 & -0.06 & 243 \\
\hline & $\begin{array}{l}\text { Important for my } \\
\text { community }\end{array}$ & $6 \%$ & $26 \%$ & $51 \%$ & $11 \%$ & $6 \%$ & 0.77 & -0.09 & 245 \\
\hline \multirow{3}{*}{ 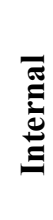 } & $\begin{array}{l}\text { Inconvenient for my } \\
\text { heirs }\end{array}$ & $8 \%$ & $33 \%$ & $39 \%$ & $12 \%$ & $8 \%$ & -0.09 & 0.75 & 242 \\
\hline & $\begin{array}{l}\text { Incompatible with } \\
\text { how I currently }\end{array}$ & $7 \%$ & $18 \%$ & $42 \%$ & $25 \%$ & $8 \%$ & -0.18 & 0.67 & 244 \\
\hline & $\begin{array}{l}\text { Expensive for me and } \\
\text { my family }\end{array}$ & $1 \%$ & $14 \%$ & $63 \%$ & $15 \%$ & $7 \%$ & 0.03 & 0.59 & 245 \\
\hline
\end{tabular}

\subsubsection{Predicting Positive Attitudes towards CEs (Question 3)}

I used logistic regression analysis to explore important factors impacting landowner attitudes towards the public and private outcomes of CEs. I found that beliefs about the environmental protection benefits of CEs was most important to landowners' external attitudes (Table 2.3). Personal experience with CEs and recreation oriented management goals were also significantly related to a positive external attitude, whereas indirect experience was inversely related. Personal experience with CEs was the only overlapping item of importance between the reduced models of internal and external attitudes. Beliefs about the financial adequacy of incentives associated with CEs and development protection management goals were significantly related to a positive internal attitude, whereas perceived risk to private ownership was inversely related. 
Table 2.3 Results of logistic regression coded to predict positive external and internal attitudes $(>0) ; 121$ and 70 observations, respectively. Significant levels: ${ }^{\dagger}(<0.1),{ }^{*}(<0.05),{ }^{* *}(<0.01), * * *(<0.001)$. Coefficients presented as odds ratios. Nagelkerke $\mathrm{R}^{2}$ presented. ANOVA revealed no significant difference between the full and reduced models.

\begin{tabular}{lcccc}
\hline & \multicolumn{2}{c}{ Full Model } & \multicolumn{2}{c}{ Reduced Model } \\
& External & Internal & External & Internal \\
\hline Attitude & 1.17 & 1.05 & & \\
Experience/Awareness Items & & & & \\
Personal Experience & $2.50^{*}$ & $2.13^{\dagger}$ & $2.60^{*}$ & $1.91^{*}$ \\
Indirect Experience & $0.59^{*}$ & 1.0 & $0.61^{*}$ & \\
Awareness & 0.97 & 0.86 & & \\
Land Trust Familiarity & 1.29 & 1.12 & & \\
Belief Items & & & & \\
Environmental Beliefs & $4.05^{* * *}$ & 0.67 & $5.20^{* * *}$ & \\
Financial Beliefs & 1.04 & $1.75^{*}$ & & $1.56^{*}$ \\
Risk Items & & & & \\
Regulation Risk & 0.95 & 0.79 & & \\
Social Risk & 0.83 & 0.92 & & \\
Private Ownership Risk & 0.99 & $0.56^{* *}$ & & $0.56^{* * *}$ \\
Management Goal Items & & & & \\
Development Protection Goals & 1.18 & $1.59^{* *}$ & & $1.55^{* *}$ \\
Habitat Goals & 1.05 & 1.12 & & \\
Recreation Goals & $1.41^{*}$ & 0.91 & $1.41^{*}$ & \\
Income Goals & 0.97 & 0.95 & & \\
\hline$(n=215)$ & $R^{2}=0.36$ & $R^{2}=0.27$ & $R^{2}=0.34$ & $R^{2}=0.24$ \\
\hline
\end{tabular}

\subsubsection{Relationship between Risk and Awareness (Question 4)}

I was specifically interested in the relationship between, awareness and attitudes, as well as between awareness and perceived risk to private ownership. I analyzed the relationship between awareness and perceived risk with a contingency table (Table 2.4). A Chi-square test revealed that the differences in frequency among the different levels of risk and awareness were significant. Most notably, the number of landowners who were unsure of the level of risk decreased with increasing awareness and the number of landowners who perceived low risk increased. 
Table 2.4 Contingency table of awareness and private property rights risk. Chi²: 42.85 , p-value: $1.11 \mathrm{e}-08$

\begin{tabular}{rcccc}
\hline & \multicolumn{4}{c}{ Private Ownership Risk Perception Level } \\
Awareness Level & Low & Unsure & High & TOTAL \\
\hline None-Very Little & $9(4 \%)$ & $49(23 \%)$ & $16(7 \%)$ & $74(34 \%)$ \\
Moderate & $21(10 \%)$ & $28(13 \%)$ & $9(4 \%)$ & $58(27 \%)$ \\
Quite a Bit & $50(23 \%)$ & $18(8 \%)$ & $15(7 \%)$ & $83(39 \%)$ \\
TOTAL & $80(37 \%)$ & $95(44 \%)$ & $40(18 \%)$ & 215 \\
\hline
\end{tabular}

\subsubsection{Research Question 5: Predicting CE Attitude Extremity}

In addition to exploring positive attitudes, I was also interested in attitude

extremity. I included four CE experience and awareness items as well as five information source items in two logistic regression models to predict external and internal attitude extremity. I found that personal experience and direct interaction with neighbors was important to an extreme external attitude (Table 2.5). Indirect awareness, learning about CEs from a peer source, and indirect interaction were important to an extreme internal attitude, whereas awareness of CEs was inversely related to an extreme internal attitude.

Table 2.5 Results of logistic regression analysis to predict attitude extremity $(>1,<-1) .32$ and 15 observed extreme external and internal attitudes, respectively. Coefficients presented as odds ratios. Significant levels: ${ }^{\dagger}(<0.1),{ }^{*}(<0.05), * *(<0.01), * * *(<0.001)$. Nagelkerke $\mathrm{R}^{2}$ presented for each model. ANOVA revealed no significant difference between the full and reduced models

\begin{tabular}{lllll}
\hline & \multicolumn{2}{c}{ Full Model } & \multicolumn{2}{c}{ Reduced Model } \\
& External & Internal & External & Internal \\
\hline Experience/Awareness Items & & & & \\
Personal Experience & 1.98 & 0.70 & $2.16^{*}$ & \\
Indirect Experience & 1.70 & $2.60^{*}$ & & $2.29^{*}$ \\
Awareness & 0.69 & $0.49^{\dagger}$ & & $0.54^{\cdot}$ \\
Land Trust Familiarity & 0.50 & 0.42 & & \\
Information Source Items & & & & \\
CE Info Source: Peer & 0.40 & $4.89^{\dagger}$ & & $5.64^{*}$ \\
CE Infor Source: NGO & 1.80 & 1.27 & & \\
Conservation Behavior & 0.97 & 1.53 & & \\
Interaction w/Neighbor: Direct & $1.71^{* *}$ & 1.32 & $1.69^{* *}$ & \\
Interaction w/Neighbor: & 1.36 & 1.70 & & $1.71^{\dagger}$ \\
Indirect & & & & \\
\hline$(n=208)$ & $R^{2}=0.21$ & $R^{2}=0.17$ & $R^{2}=0.15$ & $R^{2}=0.12$ \\
\hline
\end{tabular}




\subsection{Discussion}

\subsubsection{Complexity of attitudes towards CEs}

My findings suggest that landowners may embody two distinct attitudes towards CEs, an attitude towards how a CE impacts their private interests in the property (internal attitude) and an attitude towards how a CE impacts the public interests in the property (external attitude). This is an important consideration because it acknowledges the difference between the private and public interests impacted by a CE as well as competing self- and shared-interests that may shape landowner attitudes. Further, this dual interest in CE attitudes is supported by the difference in important predictor items in the positive internal and external attitude models. Landowner external CE attitudes are primarily influenced by beliefs related to the environmental outcomes of CEs, items which represent social or public outcomes of CEs. Conversely, landowner internal CE attitudes are more complex and influenced by a suite of equally-contributing factors. Unlike external attitudes, landowner internal attitudes are influenced by beliefs about the adequacy of financial incentives provided by CEs. Financial incentives for CEs have been found to be more important to landowners who have a stronger economic dependence on their land (Farmer et al. 2011/2015; Ernst and Wallace 2008). However, regardless of economic dependence, this study illustrates that beliefs about the adequacy of financial incentives is an important consideration when evaluating personal impacts of a CE.

The external and internal attitude dimensions of CEs may be linked to dual interest theory as utilized in past research on farmers' attitudes towards best management 
practices (Reimer et al. 2012; Thompson et al. 2014; Chouinard et al. 2008; Comer et al. 1999). Although the majority of past research specifically focuses on the trade-offs agricultural landowners face, the results of this study suggest that when evaluating CEs, private landowners in general may experience competing attitudes similar to those encountered by agricultural landowners. This may not be the case for all private land conservation behaviors as CEs are unique. CEs impact personal uses and financial outputs of the property regardless of whether the land is used for production purposes. For instance, some landowners intend to leave their land to their children. For some, CEs are seen as inconvenient for their heirs because they do not want to "tie the hands of their children" (Miller et al. 2010, p. 70; Ma et al. 2012). CEs also directly impact the value of the land by restricting future development on the property. As landowners are evaluating the personal and financial outcomes of a $\mathrm{CE}$, they are also evaluating the conservation outcomes of a CE—outcomes which extend beyond their fence line. Therefore, self- and shared-interest trade-offs are not only important for agricultural landowners, but more generally to private property owners considering CEs.

\subsubsection{Property Rights Concepts Disconnect}

Landowners who perceive a high risk of CEs "reducing the amount of land in private ownership" are less likely to have positive internal attitudes towards CEs. Consistent with Kabii and Horwitz (2006), this relationship suggests that landowners' perspectives on private property rights is an important factor when evaluating CEs. The perception that CEs reduce the amount of land in private ownership may represent a 
conflict between landowners' conceptualization of private property rights and CEs. Private property is commonly perceived as individual and absolute (Freyfogle 2007). The goals of CEs, which seek to maximize private and public interests in a property, challenge this predominant property paradigm. Therefore, a prerequisite to a positive internal attitude towards a $\mathrm{CE}$, may be a stronger community-based property rights perspective. Thus, the continued use of CEs may be beneficial in shifting private property rights perspectives towards the integration of public and private interests in property.

The finding that private property risk perceptions are important to landowner attitudes towards CEs is consistent with Kabii and Horwitz (2006) and Nowak (2012), who found that an overwhelming majority of landowners embodied strong private property rights notions and that this was a significant predictor of attitudes towards CEs. Aside from Nowak (2012) few studies have focused on understanding landowner attitudes towards CEs, especially in relation to private property rights conceptualizations. More frequently, private property rights notions are addressed in relation to private land conservation in general. Fischer and Bliss (2009) found that landowners in the Willamette Valley, OR generally thought about oaks as a private good owned exclusively by the landowner. Natural resource professionals perceived this individualistic concept of property as a barrier to serving the public good (Fischer and Bliss 2009). Furthermore, Klapproth and Johnson (2001) discuss that perspectives of "owning property without outside interference" and "absolute rights" are barriers to the adoption of agricultural conservation practices. 
The comparison between the characteristics of CEs and the dominant social understanding of property reveals a conceptual mismatch. The Western U.S. was settled following Lockean labor theory, as land was distributed on the basis that it was productively cultivated. Historic property concepts favoring absolute and individual dominion over property are thus ingrained within societal values. Landowners who encompass this perspective of property associate absolute control with ownership. CEs, by definition, detach some of the rights in the landowner's bundle of rights. The rights that have been detached from the bundle are no longer under the absolute control of the landowner, which could mean a loss of ownership to a landowner who views ownership as absolute control. As one of our survey respondents stated, "Giving ownership or an "easement" to your own property over to others results in it not being your property anymore."

A common theme throughout the survey responses was the perceived association between CEs and government regulation. The perceived risk of CEs leading to "future regulatory burdens," although not a significant predictor of CE attitude, is an important item in further understanding how landowners perceive CEs in relation to property rights. Thirty-seven percent of respondents reported that they perceived a high or very high risk of CEs causing future regulatory burdens, which illustrates that many landowners believe CEs are associated with government regulation. Landowners frequently mentioned a lack of trust in government agencies and instability of public policies as influencing their perception that CEs may result in future regulatory burdens. This perceived association between CEs and the government may be a reflection of beliefs that government agencies 
are involved in the acquisition of CEs (even those held by land trusts) or a concern that CEs may result in the identification of a publicly regulated natural resource, such as an endangered species. For instance, one respondent stated that, “Once a person gives up property rights the door is wide open to government intrusion. " Furthermore, it may also be that landowners view any outside influence (governmental or non-governmental) as a threat to their private property rights. Conceptually, landowners may not perceive a difference between land trusts and government agencies. The mission of land trusts - to protect and conserve publically valued natural and cultural resources - may be viewed as synonymous with inserting public interests into private property.

Although CEs may conflict with common private property concepts as discussed above, their continued utilization may also provide an opportunity to transition towards community-based and interconnected perspectives of property. Unlike regulations and land use laws, CEs are voluntary and may offer compensation to willing landowners, which illustrates a compromise between the extreme ends of individualistic and community-based property notions. As more landowners adopt CEs-recognizing that property can serve both private and public uses - this may promote change in social norms regarding property rights. Future research could investigate the role of CEs in shifting property rights norms comparing communities extensively utilizing CEs and those favoring the traditional outright acquisition of land. 


\subsubsection{Role of Awareness and Information Sources}

Although awareness of CEs was not found to be an important predictor in the positive attitude models does not mean that the vital role of information sharing and outreach should be discredited. Rather, we should consider that information about CEs may be influencing attitudes through more complex pathways such as 1) acting indirectly on attitudes through risk perception and 2) influencing attitude extremity. Attitude strength is defined as encompassing qualities of durability and impactfulness (Petty and Krosnick 1995), whereas attitude extremity may be described as an intensity of feeling or "lengths to which the individual would go," (Abelson 1995, pg. 38). Abelson (1995) argues that behavioral intentions are encompassed within the meaning of attitude extremity; thus, an increased understanding of CE attitude extremity may lead to improved predictability of attitudes and behaviors (Tesser et al. 1995). This exploration may be helpful in determining effective vehicles for $\mathrm{CE}$ information sharing in order to promote stable positive attitudes towards CEs.

The results of this study illustrate the indirect connection between awareness and attitudes. Awareness was found to be inversely related to landowners' perceived risk to private ownership. Although the number of landowners who perceived high risk to private ownership did not change with increasing awareness levels, the number of landowners who perceived low risk to private ownership increased. Thus, awareness may be especially important in shifting landowners who are unsure about the level of risk towards perceiving low risk. As landowners learn more about CEs this may subdue the initial conflict with private property rights notions, especially if landowners become more 
aware of the financial incentives, flexibility, and lack of government involvement. However, we should also recognize that there is a small subset of landowners who may not respond to increasing levels of awareness. A relatively consistent number of landowners perceived high risk to private ownership, regardless of awareness level. These landowners may have very strong perspectives on individual property rights and might be resistant to any loss of control—governmental or non-governmental. Despite this, the influence of awareness on the uncertainty in perceived private ownership risk illustrates a potential pathway for increased awareness to lead to $\mathrm{CE}$ attitude change.

There are many different strategies to increase knowledge and awareness; however, these strategies may not all be equivalent in terms of their impact on attitude. Landowners who first learned about CEs from a peer source (spouse, relative or neighbor) were five times more likely to have an extreme internal attitude. This corresponds to recent research in the natural resource management literature highlighting the importance of peer exchange programs in the conservation of private lands (Kueper 2009; Schubert and Mayer 2012). Peer exchange programs, such as the Master Woodland Manager Program in Oregon, have been designed to promote the natural process of information sharing observed among landowners. For instance, Schubert and Mayer (2012) found that the forest management approaches of non-industrial private forest owners were influenced both directly and indirectly by their neighbors. Similarly, Kueper (2009) found that forest owners discuss land management with their peers, including neighbors and friends. A possible reason why peer exchange programs have been successful may be related to the impact of peer information sources on attitude extremity. 


\subsubsection{Implications and Limitations}

A distinctive characteristic of the Whychus Creek Watershed is the chain of protected areas along the creek (Figure 1.2) illustrating an active conservation force in the area and landowners who are receptive to conservation goals. Though this level of conservation activity may be distinctive, the Whychus Creek Watershed is not alonemany local and national organizations throughout the U.S. aim to achieve similar patterns of land conservation. The widespread use of CEs as a primary strategy to protect critical habitat utilized in private land conservation projects (i.e. the Sage Grouse Initiative, a partnership of private landowners, non-profits, universities and businesses protecting 380,000 acres of habitat through the use of CEs) requires an improved understanding of how these changes in property ownership impact the surrounding landscape. My observations in the Whychus Creek Watershed may offer insight to this phenomenon. For instance, high levels of land conservation activity may be linked to increased awareness of conservation options. Landowners in the Whychus Creek Watershed were more aware of CEs than a random selection of landowners previously surveyed. Van Fleet et al. (2012) found that, in a survey of randomly selected forest owners in central and western Massachusetts, about half of the forest owners reported "not heard of" or "knowing nothing" about CEs. They also found that the majority of respondents reported little firstor second-hand experience with CEs (90\%). In comparison, fewer (38\%) landowners in our study reported "not heard of" or "knowing very little" whereas $62 \%$ knew at least a little about CEs. Although few landowners had first-hand experience with CEs, one third of respondents in our study knew someone who had a CE. This increased level of CE 
awareness relative to other populations may be due to the conservation activity in the area. Though high perceived risk to private ownership was a significant barrier to positive internal CE attitudes, relatively few respondents in our study perceived high risk (19\%). Therefore, the concentrated use of CEs and fee-simple acquisition for natural area protection within the Whychus Creek Watershed may also be associated with low perceived risk to property ownership. This study reveals insight that may be broadly applicable especially as CEs become more common across the landscape.

While the results of this study emphasize the complexity and importance of landowner attitudes towards CEs, it is important to note that these findings are only directly applicable to the population of private landowners in the Whychus Creek Watershed. Additionally, I wanted to acknowledge a few limitations related to my methodology. The hypothetical nature of the survey instrument used in this study may present a limitation to the accuracy of item measures. Landowners were asked generally about their attitudes, beliefs and perceived risk of CEs and were not given specific situations which might have altered their responses. As little work has focused on CE attitudes, the items I created to measure CE attitudes were based off other attitudinal measures and adapted to fit CEs. Future research should seek to improve measures used for $\mathrm{CE}$ attitudes and confirm the existence of the multi-dimensionality of CE attitudes. For instance, it might be beneficial to ask landowners qualitatively about their attitudes towards CEs in order to capture the breadth and diversity of attitude measures. 


\subsection{Conclusions}

Despite the local characteristics that are unique to the Whychus Creek Watershed, I believe that there are also common themes that are relatively consistent across geographic regions. The trade-offs associated with the evaluation of both self- and shared-interest outcomes of CEs is an experience that is unlikely to be unique to landowners in the Whychus Creek Watershed. For instance, Cross et al. (2011) conducted a survey of agricultural landowners in Colorado and Wyoming - a population of landowners that are quite different than Whychus Creek Watershed landowners and also found that landowners experience competing motivations and barriers to CE adoption. This highlights the broader applicability of the themes discussed in my study. At the parcel-scale it is important to acknowledge the challenging trade-offs landowners encounter when evaluating the use of CEs while considering at the landscape-scale how this impacts what it means to own land. 
CHAPTER 3. Foundations of Conservation Easement Conveyance: Attitudes and Attachment to the Natural and Social Community

\subsection{Introduction}

The degrading health of our lands is fundamentally a social problem. We are challenged by the legacy left by past generations and the increasingly intensive footprint of our present society. Important natural areas and ecological communities are threatened as human populations continue to grow and expand to areas once sparsely inhabited (Azuma et al. 2014). More specifically, area near public land has become an appealing option for development as people seek quality-of-life and outdoor recreational opportunities (Maestas et al. 2001), presenting an urgency to incorporate private lands in natural area conservation.

Private property is a defining quality of American culture. Built upon ideals of liberty and equality, early perspectives of property were developed to allow any man the right to privacy and self-sustenance; however, it was also recognized that these rights were subject to the common good. Beginning in the industrial age, this connection to the common good began to degrade, favoring the rights of the private individual. Now, although landowners are still expected to use their land in a way that does not harm others, the definition of "harm" has been weakened, allowing more and more intensive uses on the land. In some cases this individualistic notion of property has resulted in sprawling destruction of natural ecosystems. However, that does not mean that the institution of private property should be dismissed. For instance, some argue that a private property ownership regime may actually provide a "solution" to the Tragedy of the Commons (Hardin 1968; Smith 1981). Rather, it is the definition of property within 
the private ownership system that requires renovation. As a majority, we may favor the individual rights in property, however, in some places there has been a resurgence of community values in private property. For instance, Yung and Belsky (2007) discuss how ranchers along the Rocky Mountain Front collaborate with their neighbors attributing this to local social obligations and stewardship. Stories like this are not confined to a specific geographic region, rather, they are driven by the local community.

In this study I explore the reintegration of public values in private property by focusing on a conservation tool that, by definition, seeks to maximize the overlap between public and private values in private land. Conservation easements (CEs) are the primary tool used by land trusts (non-profit organizations that actively work to conserve land) to protect habitat, biodiversity and open space (Kiesecker et al. 2007). CEs can be described within the context of the classic metaphor of property as a "bundle of sticks" wherein each stick represents a right. CEs allow for some of the landowner's rights to be separated from the bundle and voluntarily sold or donated. When a landowner decides to place a CE on their property they continue to own the property but the uses and/or management practices that would negatively affect the conservation values are limited or prohibited. Further, a CE represents an individually-crafted legal agreement between a landowner and an eligible organization, such as a land trust or government agency. Considering the growth in CEs - local and state land trusts hold 8.8 million acres of CEs (Chang 2011), a large increase from the 450,000 acres held by local and state land trusts in 1990 (Bray 2005) - it is important to expand our understanding of landowner interest in CEs (Kabii and Horwitz 2006; Merenlender et al. 2004). 
My interest in the relationship between the common good and private property in CEs requires an incorporation of elements that extend beyond individual-level behavioral influences; thus, I sought to connect the landowner to their surroundings by considering attachment to place and community. I begin by presenting a brief summary of general behavioral theories such as the theory of planned behavior (Ajzen 1991), diffusion of innovations theory (Rogers 2003) and dual interest theory (Lynne 1999). I then discuss the sense of place and community literature in order to consider how individuals' connection to place and community may influence conservation behavior.

\subsubsection{Parcel-Level: Key Components of Individual Behavior}

The theory of planned behavior (TPB), a commonly used theoretical framework for predicting human behavior, states that behavior directly follows from behavioral intention, which is influenced by attitudes towards the behavior, perceived behavioral control and subjective norms. Though the TPB has been extensively utilized throughout research on natural resource management it has rarely been applied to CEs. Among the few studies that have applied the TPB to CEs, both Nowak (2012) and Brain et al. (2014) found that attitudes and subjective norms were significant predictors of landowner intention to adopt a CE. The diffusion of innovation theory (DOI) also provides guidance in understanding behavior stating that innovations which provide an advantage to the user, are compatible with existing norms and values, are not complex and easily experienced through trial and observation, lead to increased rates of adoption (Rogers 
2003). In this study I use components of both the TPB and DOI to evaluate their relative importance to CE adoption.

As is evident in the TPB and DOI, models of human behavior often support the representation of humans as the rational ego, motivated to maximize self-interested utility. Although the TPB and DOI may not depict behavior as completely self-serving, the primary focus is on individually perceived complexity, advantage and attitudes. However, this may not always provide a realistic representation of human behavior. Lynne (1999) described the co-existence of both a self-interest and other-interest, arguing for a dual interest framework to recognize "a purposive actor embedded in a social system" (p.268). Though not explicitly represented in a dual interest framework, these are not new ideas in the CE literature. Ernst and Wallace (2008) surveyed landowners who had participated in CEs and found that landowners were motivated more by natural resource protection and community goals than by financial incentives or family/estate matters suggesting that shared-interests may play an important role in CE adoption. This "shared-interest" or "other-interest" can be represented as social—neighbors, family, the community, the public in general—or as an ecological/environmental interest. Thus, individuals may not always be influenced by dual interests depending on the depth and valence of their connection to the "other." Further, Ernst and Wallace (2008) argue that the importance of financial incentives should not be dismissed as financial incentives provide a means for realizing both self- and shared-interests.

In both the TPB and DOI, advantage, complexity and perceived behavioral control suggest that incentives may play a role in motivating behavior, especially when 
the behavior may not present a direct advantage to the individual. Koontz (2001) compared monetary and nonmonetary motivations for different land use activities concluding that landowners who were dependent on their parcel for income, owned more land, had lower household income and lower educational attainment were more likely to be motivated by financial benefits. Farmer et al. (2015) built upon this study and found that landowners who did not engage in economic land use activities were more likely to convey a CE without a tax incentive. In a study of cattle ranchers, Brain et al. (2014) found that financial incentives were a significant factor in determining likelihood to convey a CE. In this study I consider how landowner response to incentives may provide insight to the balance between self- and shared-interests in property.

\subsubsection{Parcel of the Community: Place Protective Behavior}

In America, private property, which once derived meaning from the public good, is now perceived as distinct from the public sphere and has come to primarily reflect a self-interested perspective. However, this individualistic and absolute notion of property is based on the enduring myth "that property rights somehow began in absolute form and only deviated from that pure form with the advent of modern land-use controls," (Freyfogle 1996, p. 178). Rather, Freyfogle (1996) argues that property rights actually include two distinct components - the right to use the land (self-interested) and the responsibility to do no harm (shared-interest). Thus, property can also be conceptualized utilizing a dual interest framework such that the "self-interest" relates to the individual property rights and the "other-interest" relates to the common good. Although the 
common good in property has been buried by myths of individual and absolute perspectives of ownership, connecting the institution of property to place may help uncover this forgotten ideal.

On the surface, our landscape is characterized by boundaries of ownership highlighting the stark contrast between public and private goods, but within these boundaries is a place. Beyond the legal institution of property, land represents a place shaped by layers of experience and aspiration, creating shared memories, "a structure of feeling” (Williams 1977; Agnew 1993), “a center of meaning” (Tuan 1979; Jorgenson and Stedman 2001). Tuan (1979) distinguishes between the physical (or natural) and human elements of place stating that "place may be said to have 'spirit' or 'personality' but only human beings can have a sense of place," (p. 410). Places can be described as "public symbols" defined visually, promoting attention and awe, and as "fields of care" representing the places in which our emotion is expressed and anchored (p.412, Tuan 1979). Recognizing property as a place reintegrates the individual parcel into the landscape as place derives meaning from relationships between an individual and the surrounding natural and social community. Though both the natural and social environment define a place, they are often separated in the literature.

The importance of sense of place increasingly receives attention in the natural resource management and conservation literature and is typically represented as a relationship between an individual and the natural environment encompassing variations of three dimensions: place identity, place attachment and place dependence. Place identity can be defined as "those dimensions of self that define the individual's personal 
identity in relation to the physical environment" (Proshansky 1978, p. 155; Jorgensen and Stedman 2001). Place attachment can be described as the positive emotional connection between individuals (or sometimes groups of people) and their environment (Jorgensen and Stedman 2001). Lastly, place dependence highlights the role of behavioral connection such that a specific place serves an individual's goals better than other places (Jorgensen and Stedman 2001).

In contrast, the sociology literature focuses more on the social dimensions of place and community attachment. McMillan and Chavis (1986) define sense of community as composed of four elements: membership, influence, integration and fulfillment of needs and shared emotional connection. Membership describes a feeling of belonging or investing oneself to be a member as well as a "willingness to sacrifice for the group," (McMillan and Chavis 1986, p. 10). Influence describes both the influence exerted by the group over the individual member and the influence of a member over what the group does. Integration and fulfillment of needs involves the behavioral motivator of reinforcement such that the "individual-group association must be rewarding for its members," (McMillan and Chavis 1986, p. 12). Lastly, shared emotional connection is related to a shared history, which is not necessarily dependent on participation but on identification (McMillan and Chavis 1986).

The difficulty in distinguishing between sense of place and sense of community emphasizes the importance of both the physical and social environment when seeking to describe the meaning of place. Some researchers have incorporated both physical and social dimensions into community attachment arguing that this integration is especially 
useful when examining how people living next to protected natural areas connect to their community (Brehm et al. 2004; Clark and Stein 2003). Mesch and Manor (1998) conclude that both "locally based social relationships and satisfaction with the environment are related to the development of place attachment," (p. 518).

As a meaningful expression of relationships between people and their social and physical environment, place is an integral part of why people engage in collective action to protect a place of shared meaning or conserve the natural qualities of a property (Norton and Hannon 1997; Erickson et al. 2002; Vaske and Kobrin 2001; Lokocz et al. 2011; Nielsen-Pincus et al. 2014). Past research in natural resource management has investigated the role of sense of place as a predictor of pro-conservation behavior. Stedman (2002) found that higher place attachment and lower place satisfaction are associated with place protection behavior. More specifically, Farmer et al. (2011) found that place attachment was the primary motivating factor for landowners who had conveyed a CE. Although the natural resource management literature typically portrays sense of place as the relationship between self and the natural environment, connections to the social community may also play a key role in conservation behavior. Clark and Stein (2003) found that "residents identify with different aspects of their community; for some residents the physical-natural landscape is an important part of how they relate to their community. Both socially and landscape-oriented stakeholders indicated high levels of attachment with the community," (p.875). Further, Ernst and Wallace (2008) highlight the role of "community-mindedness" as a motivator for participation in private land conservation programs. Attachment to both the natural and social community within a 
place may be a motivating factor in $\mathrm{CE}$ adoption as well as fundamental to the connection between the common good and private property.

\subsubsection{Research Objectives}

In this study I strive to weave together components of behavioral theory and place attachment in order to contribute to the discussion of land conservation and the resurgence of community interests in property. More specifically, the research questions guiding this study are:

1. How do individual characteristics (TPB: attitudes, perceived behavioral control, subjective norms; DOI: complexity and advantage; demographics) and external relationships (connections to social and natural community, length of ownership) influence likelihood of conveying a CE?

2. Which of the above characteristics differentiates those who are Likely to convey a CE and those who are Unsure or Unlikely to convey a CE?

\subsection{Methods}

\subsubsection{Study Area}

This study takes place in the Whychus Creek Watershed (Deschutes County, OR) near the small city of Sisters. Deschutes County has been experiencing increases in population and is one of the fastest growing counties in Oregon. The population of Sisters has more than doubled between 2000 and 2010, growing from 961 to 2,038. Private land conservation is especially important along lower Whychus Creek as it is predominantly 
privately owned and vulnerable to increases in development as the area provides attractive outdoor recreational opportunities and quality-of-life resources. Whychus Creek is a valued ecological, scenic and cultural resource and has been the target of conservation and restoration efforts for 30 years. Figure 1.2 illustrates the distinction between public and private land in the watershed as well as a string of privately protected lands. The Deschutes Land Trust has conserved 2,200 acres of land surrounding Whychus Creek which speaks to the commitment of the community to environment.

\subsubsection{Sample Selection}

The target population for this study consisted of private landowners owning five acres or more within the Whychus Creek Watershed. Private landowners who owned property directly adjacent to Whychus Creek or to property protected by Deschutes Land Trust were also included regardless of the five-acre minimum criteria—although these exceptions may contain small acreage properties they have the potential to create substantial impacts on conservation within the Watershed due to their location. Based on these criteria I used ESRI ArcMap software to create a sample frame from Deschutes County 2014 GIS taxlot data. After removal of all ineligible units the target population consisted of 756 landowners. Following suggestions from Dillman (2000) I determined that a sample size of 255 would be necessary to represent the population. Assuming a $40 \%$ response rate and 5\% undeliverable rate I selected a random recruitment sample of 664 landowners. 


\subsubsection{Data Collection}

During August and September 2015, I implemented a mixed-mode survey based on the Tailored Design Method (Dillman 2000). The selected sample of 664 landowners were mailed an introductory postcard that included the link to the online version of the questionnaire (day 1). Landowners were then mailed a large manila envelope containing the survey packet (day 9). Following the mailing of the survey packet I sent landowners a postcard, thanking those who had already responded and reminding those who had not completed the questionnaire to please do so (day 17). Lastly, I sent all landowners who had not responded a second packet of survey materials (day 35).

The questionnaire included 38 questions organized into six sections in which the majority of the questions were 5-point Likert-style items. The items utilized in this study are summarized in Table 3.1. I assessed landowner intention to convey a CE on a 5-point Likert-scale from "Very Likely" to "Very Unlikely" by asking: "In general, how likely or unlikely would you be to place a conservation easement on your property?” I also measured landowner response to five different incentives: 1) property tax benefit, 2) estate tax benefit, 3) income tax benefit, 4) paid the value of the $\mathrm{CE}$ and 5) property rights assurances. Attitude items were measured on a 5-point bipolar Likert-scale from "Strongly Agree" to "Strongly Disagree" based on past research studies (Greiner 2015; Balram and Dragićević 2005). I created an "internal attitude" and "external attitude" index based on the results of an exploratory factor analysis (see Chapter 2). I used the 12item Sense of Place Index developed and tested by Jorgensen and Stedman (2001) to measure landowner connection to the natural environment. Based on past research 
studies, sense of place was represented as an additive index variable (Nielsen-Pincus et al. 2014). I used the 8-item Brief Sense of Community Index developed by Peterson et al. (2008) to measure landowner connection to their social community. I represented sense of community using the four hypothesized factors: membership, influence, integration and fulfillment of needs and shared emotional connection. Although, the Brief Sense of Community Scale was designed to measure sense of community within a neighborhood, and not necessarily the rural landscape of the Whychus Creek Watershed, I thought that the dimensions represented in the scale were still relevant and applicable. I also included length of ownership (years) as a measure of community and place connection (McMillan and Chavis 1986; Brehm et al. 2004). Based on past research studies, I included two demographic items in the analysis: property size and political views (Brenner et al. 2013; Jorgensen and Stedman 2006; Nielsen-Pincus et al. 2014). I measured political views on a 5-point bipolar Liker-scale from "Very Conservative" to "Very Liberal." The survey instrument was reviewed by experts (land conservation professionals including Deschutes Land Trust staff, and individuals in academia) and a purposively selected group of landowners.

\subsubsection{Data Analysis}

I used a multinomial logistic regression to explore the relationship between variables of interest and intention to convey a CE. Multinomial logistic regression is an extension of binary logistic regression allowing for more than two response categories. The response variable, referred to as baseline interest in conveying a CE, was recoded 
into three categories: Unlikely, Unsure and Likely. Multinomial logistic regression was an appropriate analysis method because I was interested in both determining influential factors predicting Likely to convey a CE, and describing the difference between those who were Unsure and those who were Likely to convey a CE. I assessed all models for potential multi-collinearity issues by comparing correlations between the independent variables and calculating the Variance Inflation Factor (VIF). Length of ownership and property size were log transformed which appropriately addressed issues of non-normal distributions. All statistical analyses were performed in " $\mathrm{R}$ " version 3.0.2.

\subsection{Results}

\subsubsection{Descriptive Results}

I received 257 responses to the survey, yielding a response rate of $41 \%$. The majority of survey respondents were older than 50 years of age and, in comparison to the general population in the Whychus Creek Watershed (US Census 2013), had a higher level of education and above-average income-which is likely the result of my target population being landowners rather than the general population. Most survey respondents specified that they use their property as a primary residence and live on their property more than nine months out of the year. The average number of years that survey respondents have owned property in the Watershed was 18 years, ranging from less than one year to 65 years, with a median length of 15 years. The average property size was 39 acres, ranging from less than one acre to greater than 2,000 acres, with a median property 
size of 10 acres. Political views were evenly distributed between conservative and liberal perspectives.

The majority of survey respondents did not express an interest in conveying a $\mathrm{CE}$ as $48 \%$ reported that they were Unlikely, 39\% were Neither Likely nor Unlikely (i.e. Unsure) and 13\% were Likely to convey a CE. However, of those who expressed a baseline interest of Unsure, $78 \%$ shifted to Likely if offered an incentive and $44 \%$ of those who expressed a baseline interest of Unlikely shifted to Likely if offered an incentive. Table 3.2 describes the percentage of landowners within the Unsure and Unlikely baseline interests who shifted to Likely to convey a CE when offered an incentive.

Most respondents expressed neutral attitudes towards CEs, however, at least one third of respondents agreed that CEs are good for fish and wildlife habitat and useful to protect land from development. About $25 \%$ of respondents reported that they thought their community was supportive of CEs. In terms of connections to place and community, respondents reported high levels of sense of place and sense of community. Approximately $50 \%$ of respondents agreed with the following statements about the Whychus Creek Watershed: 1) I really miss it when I am away too long, 2) It reflects the type of person I am, 3) I feel I can really be myself when I am there and 4) It is my favorite place. More than $50 \%$ of respondents agreed with the following statements about their community in the Watershed: 1) I can get what I need in my community, 2) I feel connected to my community, 3) I feel like a member of my community, 4) I have a good bond with others in my community and 5) I belong in my community. 
Table 3.1 Survey responses to items used to construct model variables. Cronbach's alpha in parentheses.

\begin{tabular}{|c|c|c|c|}
\hline Variables & Mean & SD & $\mathbf{N}$ \\
\hline RESPONSE VARIABLE: Intention to convey a CE & -0.58 & 1.05 & 245 \\
\hline \multicolumn{4}{|l|}{ INCENTIVE RESPONSE ITEMS } \\
\hline Property Tax Benefit & 0.32 & 1.12 & 235 \\
\hline Estate Tax Benefit & 0.20 & 1.14 & 236 \\
\hline Income Tax Benefit & 0.30 & 1.12 & 237 \\
\hline Paid Value of CE & 0.35 & 1.15 & 235 \\
\hline Property Rights Assurances & 0.34 & 1.13 & 237 \\
\hline \multicolumn{4}{|l|}{ ATTITUDE ITEMS } \\
\hline External Attitude (0.81) & 0.27 & 0.90 & 245 \\
\hline Good for fish and wildlife habitat & 0.43 & 1.14 & 244 \\
\hline Useful to protect my land from development & 0.24 & 1.09 & 243 \\
\hline Important for my community & 0.15 & 0.93 & 245 \\
\hline Internal Attitude (0.70) & 0.00 & 0.74 & 245 \\
\hline Convenient for my heirs & -0.23 & 1.02 & 242 \\
\hline Compatible with how I currently manage my land & 0.10 & 1.01 & 244 \\
\hline Inexpensive for me and my family & 0.12 & 0.77 & 245 \\
\hline Perceived Advantage & -0.21 & 0.80 & 243 \\
\hline Perceived Ease & -0.07 & 0.73 & 242 \\
\hline Subjective Norms & 0.18 & 0.81 & 215 \\
\hline \multicolumn{4}{|l|}{ PLACE ITEMS } \\
\hline Sense of Place Index $(0.90)^{*}$ & 3.76 & 5.76 & 239 \\
\hline It is my favorite place to be & 0.55 & 0.85 & 240 \\
\hline As far as I am concerned, there are better places to be* & -0.19 & 0.88 & 239 \\
\hline It is the best place for doing the things I enjoy & 0.45 & 0.80 & 238 \\
\hline $\begin{array}{l}\text { I would enjoy the activities I undertake there just as well in another } \\
\text { place* }\end{array}$ & 0.09 & 0.87 & 235 \\
\hline It reflects the type of person I am & 0.65 & 0.77 & 234 \\
\hline I feel that I can really be myself when I am there & 0.60 & 0.86 & 237 \\
\hline I really miss it when I am away too long & 0.60 & 0.92 & 235 \\
\hline I feel happiest when I am there & 0.44 & 0.85 & 234 \\
\hline I don't really identify with the Whychus Creek Watershed* & -0.42 & 1.04 & 238 \\
\hline \multicolumn{4}{|l|}{ COMMUNITY ITEMS } \\
\hline Needs Fulfillment (0.56) & 0.44 & 0.63 & 237 \\
\hline I can get what I need in my community & 0.63 & 0.76 & 237 \\
\hline My community helps me fulfill my needs & 0.24 & 0.76 & 233 \\
\hline Emotional Connection $(0.86)$ & 0.60 & 0.76 & 239 \\
\hline I feel connected to my community & 0.61 & 0.80 & 238 \\
\hline I have a good bond with others in my community & 0.59 & 0.82 & 235 \\
\hline Membership (0.87) & 0.60 & 0.76 & 238 \\
\hline I feel like a member of my community & 0.61 & 0.82 & 237 \\
\hline I belong in my community & 0.58 & 0.80 & 236 \\
\hline Influence $(0.65)$ & 0.12 & 0.75 & 238 \\
\hline I have a say about what goes on in my community & 0.06 & 0.90 & 237 \\
\hline People in my community are good at influencing each other & 0.17 & 0.81 & 236 \\
\hline Length of Ownership (years) & 18.32 & 12.92 & 254 \\
\hline \multicolumn{4}{|l|}{ DEMOGRAPHIC ITEMS } \\
\hline Property Size (acres) & 39.09 & 150.65 & 255 \\
\hline Political Views & -0.04 & 1.25 & 227 \\
\hline
\end{tabular}


*Sense of Place Index on scale of -18 to 18 . All items that were negatively worded were inverse coded. All other ordinal variables are on a scale of -2 to 2 where -2 is "Strongly Disagree" (or "Very Liberal" for Political Views) and 2 is "Strongly Agree" (or "Very Conservative" for political views).

Table 3.2 Percentage of respondents within the Unsure and Unlikely baseline interest group that shifted to Likely to convey a $\mathrm{CE}$ if offered an incentive.

\begin{tabular}{llllll}
\hline \multirow{2}{*}{ Baseline Interest } & \multicolumn{4}{c}{ Percentage Likely to Convey CE } \\
& $\begin{array}{l}\text { Property } \\
\text { Tax }\end{array}$ & $\begin{array}{l}\text { Estate } \\
\text { Tax }\end{array}$ & $\begin{array}{l}\text { Income } \\
\text { Tax }\end{array}$ & $\begin{array}{l}\text { Paid the Value } \\
\text { of CE }\end{array}$ & $\begin{array}{l}\text { Property Rights } \\
\text { Assurances }\end{array}$ \\
\hline Unsure & $61 \%$ & $55 \%$ & $54 \%$ & $55 \%$ & $65 \%$ \\
Unlikely & $28 \%$ & $24 \%$ & $27 \%$ & $33 \%$ & $28 \%$ \\
\hline
\end{tabular}

\subsubsection{Multinomial Regression Results}

Multinomial logistic regression results are presented in Table 3.3. I found that external and internal attitudes towards CEs were highly significant items differentiating between Unsure and Unlikely, whereas only external attitude was important when comparing Unsure and Likely. Perceived ease (i.e. behavioral control), subjective norms and financial advantage (TPB and DOI variables) were not significant predictors in the model; though perceived ease was slightly significant when comparing Unsure and Likely. Sense of place was a significant item when comparing Unsure and Unlikely whereas sense of community items (emotional connection and membership) appeared to be important when comparing Unsure and Likely. The demographic variable, length of ownership, was the only item that was significant to both Unlikely and Likely. Lastly, different demographic items were important for predicting inclusion in the Unlikely or Likely response category. Political views were important in differentiating between Unsure and Unlikely and property size was an important factor differentiating between Unsure and Likely. 
Table 3.3 Multinomial logistic regression predicting general intent to adopt a conservation easement structured as three discrete categories (Likely [27], Unsure [72], Unlikely [86]) where "Unsure" is the reference category. $\mathrm{N}=185$. Significant levels: $*(<0.10),{ }^{* *}(<0.01),{ }^{* * *}(<0.001)$. McFadden $\mathrm{R}^{2}: 0.32$. $\mathrm{Chi}^{2}: \mathrm{p}<0.001$

\begin{tabular}{llllll}
\hline Unsure vs. Unlikely & B & $\exp (\mathbf{B})$ & SE & $\mathbf{Z}$ & p-value \\
\hline Intercept & -0.38 & 0.69 & 0.67 & -0.56 & 0.57 \\
External Attitude & -1.01 & 0.36 & 0.35 & -2.92 & $0.003^{*}$ \\
Internal Attitude & -0.78 & 0.46 & 0.35 & -2.21 & $0.03^{*}$ \\
Financial Advantage & -0.62 & 0.54 & 0.44 & -1.41 & 0.16 \\
Perceived Ease & 0.18 & 1.19 & 0.40 & 0.44 & 0.66 \\
Subjective Norms & -0.19 & 0.83 & 0.30 & -0.64 & 0.52 \\
Sense-of-Place & -0.09 & 0.91 & 0.04 & -2.19 & $0.03^{*}$ \\
Emotional Connection & 0.24 & 1.27 & 0.55 & 0.43 & 0.67 \\
Needs Fulfillment & -0.08 & 0.92 & 0.50 & -0.17 & 0.87 \\
Membership & 0.96 & 2.61 & 0.63 & 1.54 & 0.12 \\
Influence & -0.29 & 0.75 & 0.34 & -0.86 & 0.39 \\
Log(Length of Ownership (Years)) & -0.27 & 0.76 & 0.13 & -2.03 & $0.04 *$ \\
Log(Property Size (Acres)) & 0.34 & 1.45 & 0.24 & 1.57 & 0.12 \\
Political Views & 0.30 & 1.34 & 0.17 & 1.74 & $0.08^{*}$ \\
Unsure vs. Likely & $\mathbf{B}$ & $\mathbf{e x p ( B )}$ & $\mathbf{S E}$ & $\mathbf{Z}$ & $\mathbf{p - v a l u e}$ \\
\hline Intercept & -2.26 & 0.10 & 0.89 & -2.53 & $0.01^{*}$ \\
External Attitude & 0.96 & 2.61 & 0.55 & 1.75 & $0.08^{*}$ \\
Internal Attitude & 0.34 & 1.40 & 0.45 & 0.76 & 0.45 \\
Financial Advantage & -0.35 & 0.71 & 0.49 & -0.71 & 0.48 \\
Perceived Ease & 0.86 & 2.37 & 0.48 & 1.72 & $0.09^{*}$ \\
Subjective Norms & 0.56 & 1.76 & 0.41 & 1.36 & 0.17 \\
Sense-of-Place & 0.03 & 1.03 & 0.06 & 0.54 & 0.59 \\
Emotional Connection & 1.52 & 4.60 & 0.86 & 1.77 & $0.08^{*}$ \\
Needs Fulfillment & 0.74 & 2.09 & 0.80 & 0.92 & 0.36 \\
Membership & -1.56 & 0.21 & 0.92 & -1.70 & $0.09^{*}$ \\
Influence & -0.08 & 0.92 & 0.46 & -0.18 & 0.85 \\
Log(Length of Ownership (Years)) & 0.38 & 1.46 & 0.18 & 2.05 & $0.04^{*}$ \\
Log(Property Size (Acres)) & -0.64 & 0.53 & 0.32 & -2.02 & $0.04^{*}$ \\
Political Views & 0.02 & 1.02 & 0.23 & 0.09 & 0.93 \\
\hline & & & & &
\end{tabular}

\subsection{Discussion}

\subsubsection{Attitudes: Foundation of CE Conveyance}

According to the Theory of Planned Behavior (TPB; Ajzen 1991), behavioral intention is directly influenced by attitudes towards that behavior (as well as perceived behavioral control and subjective norms). Dual Interest Theory (Lynne 1999) also seeks to explain human behavior by recognizing both self- and other-interests in behavioral 
tendencies. Consistent with past research, the results of the regression analysis highlight the importance of both external and internal attitudes in understanding behavioral intentions to adopt a CE (Nowak 2012; Brain et al. 2014). External and internal attitudes towards CEs exhibited similar levels of association with behavioral intention suggesting that it is necessary for a landowner to have both a positive attitude towards the personal as well as the social or ecological outcomes of a CE. However, when differentiating between landowners who are Unsure and those who are Likely to convey a CE, external attitudes appear to be more important than internal attitudes. This supports past research utilizing a dual interest framework to conceptualize the trade-offs that agricultural landowners face when making land management decisions (Chouinard et al. 2008; Thompson et al. 2014). Similar to the agricultural landowners in these studies, when considering a $\mathrm{CE}$, landowners are not only thinking about how a $\mathrm{CE}$ would impact them personally, but also how it impacts the community (both ecologically and socially).

Though the results illustrate a strong link between attitudes and behavior, I also found evidence of a gap in this connection. Positive external and internal attitudes are important when comparing Unsure and Unlikely, but external attitudes were only slightly significant when differentiating between Unsure and Likely, meaning that having positive attitudes towards CEs does not necessarily lead to being Likely to convey a CE. Heberlein (2012) argues that although attitudes are a key component of behavior, there are other situational and experiential factors at play. For instance, in a research study of hunting behavior, those who had negative attitudes towards hunting did not hunt and those that hunted did not have negative attitudes (Heberlein 2012; Ljung et al. 2012), however, the 
majority of people who had positive attitudes towards hunting did not hunt, suggesting that there are other important factors. Similarly, there was a large proportion of respondents who had positive attitudes towards CEs, but were not likely to convey a $\mathrm{CE}$ (62\% of respondents in the Unsure response category had positive external CE attitudes). The regression was built to predict baseline interest in conveying a CE, thus, there may be specific situational factors constraining respondents' intention. Landowners in the Unsure response category may be uncertain about the specific circumstances related to CE conveyance such as the financial costs and benefits. When offered at least one of the five incentives over $75 \%$ of those whose baseline interest was Unsure shifted to Likely to convey a CE. While personal costs and benefits were important to those in the Unsure group, positive external and internal attitudes provided the necessary first step towards CE conveyance.

\subsubsection{Connection to Place: Motivation for CE Conveyance}

Items representing landowner connection to both the surrounding natural and social community were significant predictors of likelihood to convey a CE. However, I found that the social and natural dimensions of place attachment do not interact with $\mathrm{CE}$ adoption in the same way. Consistent with past research, higher levels of sense of place were related to an increase in the likelihood of CE adoption (Cross et al. 2011; Farmer et al. 2011; Ernst and Wallace 2008). While sense of place was significant in the models, its impact was much smaller relative to external and internal attitudes. Similarly, Mullendore et al. (2015) also reported a significant yet weak association between sense of place and 
conservation behavior suggesting that sense of place may be less important when compared to other factors. Further, this may be indicative of the difference between place protective behaviors in general and the specific behavior of adopting a CE.

In addition to sense of place, I found that sense of community may be related to $\mathrm{CE}$ adoption, though different dimensions of sense of community seem to impact $\mathrm{CE}$ adoption in different ways. An increase in emotional connection to the community and a decrease in membership were slightly significant when moving from Unsure to Likely. This suggests that landowners who are emotionally connected to their social community may be more likely to convey a CE. On the other-hand, membership seems to decrease the likelihood of conveying a CE; however, this may be a relationship unique to the Whychus Creek Watershed. There is a high level of conservation activity occurring in the Watershed, thus, landowners who feel like they are a member of this community may not see a need for CEs. Landowners who were Unsure reported the lowest levels of overall sense of community suggesting that sense of community may manifest in different ways, pushing landowners toward Likely or Unlikely depending on the more specific connections they have with their community. For instance, the development of a strong emotional connection to the community may shift intentions towards Likely to convey a CE.

Length of property ownership was a significant variable describing the difference between landowners who were Unsure and those who were Likely to convey a CE (as well as Unsure vs. Unlikely). This item may be capturing an important component of place attachment, time, that might not have been adequately addressed in the sense of 
place and sense of community scales. Relph (1976) discusses the relationship between time and place suggesting that "places themselves are the present expressions of past experiences and events and of hopes for the future," (p.33). Nielsen-Pincus et al. (2010) found that length of residence was positively related to place attachment. Though it is possible for an attachment to place and community to develop in a short amount of time, the depth and meaning of this relationship may be expanded over time as a history of moments and experiences is developed. Time may be even more influential if the place that this time was spent is home, which is important to consider in this study as most respondents reported that the primary use of their property was for a residence. Relph (1976) explains that "home in its most profound form is an attachment to a particular setting, a particular environment, in comparison with which all other associations with places have only a limited significance,” (p. 39). In support of this concept, Lokocz et al. (2011) found that residents who grew up in an area had higher levels of place attachment in comparison to long-term residents who did not grew up in an area. When a foundation of positive attitudes towards CEs has already been established—which describes landowners in the Likely and Unsure category - these results suggest that sense of community and, maybe more importantly, a history of place, may be an important driving factor of CE conveyance.

\subsection{Conclusion and Limitations}

The Whychus Creek Watershed is unique in that there is a chain of protected areas along the creek (Figure 1.2) illustrating an active conservation force in the area and 
landowners who are receptive to conservation goals. The results of this study suggest that connections to both the natural and social environment may play an important role in the effective private land conservation occurring in the Whychus Creek Watershed. The distinction between connections to the natural environment and social community may be important practically as landowners may be motivated differently by the natural environment or social community. For instance, when presenting CEs to those who are Unsure about conveying a CE, it may be more important to highlight the environmental or physical place-based benefits of CEs rather than the social or cultural benefits. Additionally, landowners may be motivated differently by the monetary and nonmonetary benefits of CEs; while 39\% of landowners expressed a baseline interest of Unsure, more than $75 \%$ shifted to Likely when offered an incentive. This suggests that, in comparison to those who expressed a baseline interest of Likely to convey a CE, those in the Unsure group may place more weight on personal financial benefits or may be situationally limited in their ability to convey a CE.

While the results of this study emphasize the importance of sense of place and community to CEs, the findings are only directly applicable to the population of private landowners in the Whychus Creek Watershed. Future research is needed to explore these ideas further by comparing landowners in study areas with varying levels of sense of place and community. Additionally, I would like to acknowledge a few limitations related to the methodology. While I believe that the Brief Sense of Community Scale allowed me to capture theorized components of community attachment such as emotional attachment or membership, I was unable to decipher what exactly this community represented to 
landowners. Therefore, in order to adequately capture landowners' relationships to the social community I found that it might be helpful to integrate a qualitative aspect to the methodology.

Despite these limitations, I believe that the general themes uncovered in this study are important considerations in CE conveyance, but also to land stewardship in general. Stewardship, or caring for the land, is a natural behavior that develops over many years of living with the land. Berry (1991, p. 390) outlines rules to living with the land which appropriately illuminates the themes central to this research study:

Land cannot be properly cared for by people who do not know it intimately, who do not know how to care for it, who are not strongly motivated to care for it, and who cannot afford to care for it. People cannot be adequately motivated to care for the land by general principles or by incentives that are merely economic. That is, they won't care for it merely because they think they should do so or merely because somebody pays them to do so. They are motivated to care for land - to live with it —insofar as their interest is direct, dependable, and permanent. 


\section{CHAPTER 4. Conclusion}

\subsection{Strong Internal and External Attitudes as Foundations for CE Conveyance}

This thesis highlights that strong positive attitudes towards - both the personal and social/ecological benefits of CEs - provide the foundation for CE conveyance. The following statements summarize the characteristics of landowner interest in CEs.

- Landowners are unlikely to convey a CE if they 1) have negative attitudes towards CEs in general, 2) have only positive attitudes towards the external benefits of CEs or 3) have only positive attitudes towards the personal benefits of CEs.

- Positive external attitudes towards CEs are primarily influenced by landowner beliefs about the characteristics of CEs, which may be shifted through increased awareness and knowledge of CEs.

- Positive internal attitudes towards CEs are influenced by a suite of factors including beliefs about the financial benefits of CEs and perceived risk to private ownership. Both financial beliefs and perceived risk may also be impacted through increased awareness and knowledge of CEs. However, those who perceive a risk to private ownership with entrenched perspectives on property rights may not respond to increased knowledge.

- Learning about CEs from a peer source is an important component of attitude extremity, thus, programs which encourage the exchange of information between peers may be beneficial in developing strong and stable attitudes towards CEs 
(however, the direction of extremity will depend on the attitude valence of those sharing information).

4.2 Incentives and Connections to Community as Motivations for CE Conveyance While positive attitudes towards CEs provide the foundation for CE conveyance, alone they may not be enough to generate interest in conveying a CE. Landowners must also be strongly connected to their social and/or natural community. These connections supply the motive for $\mathrm{CE}$ conveyance as those not connected to place may not see a reason for a $\mathrm{CE}$, except when offered a personal incentive.

- Landowners who have a strong emotional connection to their social community are more likely to convey a CE.

- Landowners who have a strong sense of place are more likely to convey a CE.

- When discussing CEs with landowners it may be important to stress how CEs benefit both the social and natural community as landowners may connect to different aspects of place.

- Landowners who may not be strongly connected to their social or natural community, may respond to personal incentives for CE conveyance.

\subsection{Final Thoughts}

Although my thesis is specific to conservation easements and geographically limited to a small community in Deschutes County, Oregon, I think the overarching theme of community connection is more broadly applicable. Before coming to Portland 
State University, I worked for a private foundation in Chicago, Illinois. I was fortunate enough to work with many land trusts and local government agencies, many of which were driven by passionate, hard-working individuals devoted to conserving land. While assisting with the development of a new grant program focused on community stewardship, I gained insight to the role of community in land protection, learning that a strong community spirit often provides the backbone for effective land protection. Though these are well-known ideas in the land protection community, they are often overlooked in the literature. Thus, I conclude by reminding us of the community spirit in private land conservation. Conserving land involves weaving together individual perspectives to tell a story about a community and their connection to the landscape. 


\section{REFERENCES}

Abelson, R. 1995. Chapter 2: Attitude Extremity. In Attitude Strength: Antecedents and Consequences. Petty, R., and J. Krosnick, pp.25-42. Mahwah, NJ: Lawrence Erlbaum Associates, Inc.

Agnew, J. 1993. Representing space: space, scale and culture in social science. In Place/Culture/Representation. Duncan, J., and D. Ley, pp. 251-271. London and New York: Routledge.

Ajzen, I. 1991. The theory of planned behavior. Organizational Behavior and Human Decision Processes 50: 179-211.

Azuma, D. L., B. N. I. Eskelson, and J. L. Thompson. 2014. Effects of rural residential development on forest communities in Oregon. Forest Ecology and Management 330: 183-191.

Balram, S., and S. Dragićević. 2005. Attitudes toward urban green spaces: Integrating questionnaire survey and collaborative GIS techniques to improve attitude measurements. Landscape and Urban Planning 71: 147-162.

Bell, A., and G. Parchomovsky. 2005. A theory of property. Cornell Law Review 90: 531-616. 
Berry, W. 1991. Living with the land. Journal of Soil and Water Conservation.

Binder, A.R., K. E. Dalrymple, D. Brossard, and D. A. Scheufele. 2009. The soul of a polarized democracy: Testing theoretical linkages between talk and attitude extremity during the 2004 presidential election. Communication Research 36: 315-340.

Brain, R., M. Hostetler and T. Irani. 2014. Why do cattle ranchers participate in conservation easement agreements? Key motivators in decision making. Agroecology and Sustainable Food Systems 38: 299-316.

Bray, Z. 2005. Reconciling development and natural beauty: the promise and dilemma of conservation easements. Harvard Environmental Law Review 34: 120-177.

Brehm, J. M., B. W. Eisenhauer, and R. S. Krannich. 2004. Dimensions of community attachment and their relationship to well-being in the amenity-rich rural west. Rural Sociology 69: 405-429.

Brenner, J.C., S. Lavallato, M. Cherry, and E. Hileman. 2013. Land use determines interest in conservation easements among private landowners. Land Use Policy 35: 24-32. 
Bright, A. D., and M. J. Manfredo. 1997. The influence of balanced information on attitudes toward natural resource issues. Society and Natural Resources 10: 469483.

Brown, D. G., K. M. Johnson, T. R. Loveland, and D. M. Theobald. 2005. Rural land-use trends in the conterminous United States, 1950-2000. Ecological Applications 15: $1851-1863$.

Chang, K. 2011. 2010 National Land Trust Census Report: A Look at Voluntary Land Conservation in America. Washington DC: Land Trust Alliance.

Chouinard, H. H., T. Paterson, P. R. Wandschneider, and M. Adrienne. 2008. Will farmers trade profits for stewardship? Heterogeneous motivations for farm practice selection. Land Economics 84: 66-82.

Clark, J. K., and T. V. Stein. 2003. Incorporating the natural landscape within an assessment of community attachment. Forest Science 49: 867-876.

Comer, S., E. Ekanem, S. Muhammad, S. Singh, and F. Tegegne. 1999. Sustainable and conventional farmers: A comparison of socio-economic characteristics, attitudes and beliefs. Journal of Sustainable Agriculture 15: 29-45. 
Cross, J. E., C. M. Keske, M. G. Lacy, D. L. K. Hoag, and C. T. Bastian. 2011. Adoption of conservation easements among agricultural landowners in Colorado and Wyoming: The role of economic dependence and sense of place. Landscape and Urban Planning 101: 75-83.

Czap, N. V., H. J. Czap, M. Khachaturyan, G. D. Lynne, and M. Burbach. 2012. Walking in the shoes of others: Experimental testing of dual-interest and empathy in environmental choice. Journal of Socio-Economics 41: 642-653.

Dengel, J. 2014. Reviving Whychus Creek: Averting collisions between the Endangered Species Act and agricultural water use through proactive streamflow restoration. Masters of Science Thesis Project. Oregon State University.

Deschutes Land Trust. Web. http://www.deschuteslandtrust.org/. Accessed April 1, 2016.

Dillman, D. 2000. Mail and Internet Surveys: The Tailored Design Method. New York, NY: John Wiley and Sons, Inc.

Drescher, M. 2014. What is it like to take care of the land? Toward an understanding of private land conservation. Rural Society 23: 117-132.

Duncan, M. 2002. Reconceiving the bundle of rights. Environmental Law 32: 773-807. 
Erickson, D. L., R. L. Ryan, and R. De Young. 2002. Woodlots in the rural landscape: Landowner motivations and management attitudes in a Michigan (USA) case study. Landscape and Urban Planning 58: 101-112.

Ernst, T., and G. N. Wallace. 2008. Characteristics, motivations, and management actions of landowners engaged in private land conservation in Larimer County Colorado. Natural Areas Journal 28: 109-120.

Farmer, J. R., D. Knapp, V. J. Meretsky, C. Chancellor, and B. C. Fischer. 2011. Motivations influencing the adoption of conservation easements. Conservation Biology 25: 827-834.

Farmer, J. R., V. Meretsky, D. Knapp, C. Chancellor, and B. C. Fischer. 2015. Why agree to a conservation easement? Understanding the decision of conservation easement granting. Landscape and Urban Planning 138: 11-19.

Fischer, P., and J. C. Bliss. 2009. Framing conservation on private lands: Conserving oak in Oregon's Willamette Valley. Society and Natural Resources 22: 884-900.

Freyfogle, E. 1996. The construction of ownership. University of Illinois Law Review 1: 173-187. 
Freyfogle, E. 2003. The Land We Share: Private Property and the Common Good. Washington DC: Island Press.

Freyfogle, E. 2007. On Private Property: Finding Common Ground on the Ownership of Land. Boston, MA: Beacon Press.

Greiner, R. 2015. Motivations and attitudes influence farmers' willingness to participate in biodiversity conservation contracts. Agricultural Systems 137: 154-165.

Habron, G. B. 2004. Adoption of conservation practices by agricultural landowners in three Oregon watersheds. Journal of Soil and Water Conservation 59: 109-115.

Hardin, G. 1968. The rragedy of the commons. Science 162: 1243-1248.

Heberlein, T. 2012. Navigating Environmental Attitudes. Conservation Biology 26: 1240.

Hurley, J., C. Ginger and D. Capen. 2002. Property concepts, ecological thought, and ecosystem management: A case of conservation policymaking in Vermont. Society and Natural Resources 15: 295-312. 
Jackson-Smith, D., U. Kreuter, and R. S. Krannich. 2005. Understanding the multidimensionality of property rights orientations: Evidence from Utah and Texas ranchers. Society and Natural Resources 18: 587-610.

Jorgensen, B. S., and R. C. Stedman. 2001. Sense of place as an attitude: Lakeshore owners attitudes toward their properties. Journal of Environmental Psychology 21: $233-248$.

Jorgensen, B. S., and R. C. Stedman. 2006. A comparative analysis of predictors of sense of place dimensions: Attachment to, dependence on, and identification with lakeshore properties. Journal of Environmental Management 79: 316-327.

Kabii, T., and P. Horwitz. 2006. A review of landholder motivations and determinants for participation in conservation covenanting programmes. Environmental Conservation 33: 11-20.

Kalcic, M., L. Prokopy, J. Frankenberger, and I. Chaubey. 2014. An in-depth examination of farmers' perceptions of targeting conservation practices. Environmental Management 54: 795-813.

Kiesecker, J. M., T. Comendant, T. Grandmason, E. Gray, C. Hall, R. Hilsenbeck, P. Kareiva, L. Lozier, P. Naehu, A. Rissman, M. R. Shaw, and M. Zankel. 2007. 
Conservation easements in context: A quantitative analysis of their use by the Nature Conservancy. Frontiers in Ecology and the Environment 5: 125-130.

Kittredge, D. B., A. G. Short Gianotti, L. R. Hutyra, D. R. Foster, and J. M. Getson. 2015. Landowner conservation awareness across rural-to-urban gradients in Massachusetts. Biological Conservation 184: 79-89.

Klapproth, J., and J. Johnson. 2001. Understanding the Science behind Riparian Forest Buffers: Factors Influencing Adoption. Virginia Cooperative Extension.

Koontz, T. 2001. Money talks? But to whom? Financial versus nonmonetary motivations in land use decisions. Society and Natural Resources 14: 51-65.

Kueper, A. M., E. S. Sagor, and D. R. Becker. 2013. Learning from landowners: Examining the role of peer exchange in private landowner outreach through landowner networks. Society and Natural Resources 26: 912-930.

Linville, P. W. 1982. The complexity-extremity effect and age-based stereotyping. Journal of Personality and Social Psychology 42: 193-211.

Ljung, P., S. Riley, T. Heberlein, and G. Ericsson. 2012. Eat prey and love: game meat consumption and attitudes towards hunting. Wildlife Society Bulletin 36: 669-675. 
Lokocz, E., R. L. Ryan, and A. J. Sadler. 2011. Motivations for land protection and stewardship: Exploring place attachment and rural landscape character in Massachusetts. Landscape and Urban Planning 99: 65-76.

Lynne, G. D. 1999. Divided self models of the socioeconomic person: the metaeconomics approach. The Journal of Socio-Economics 28: 267-288.

Ma, Z., B. J. Butler, D. B. Kittredge, and P. Catanzaro. 2012. Factors associated with landowner involvement in forest conservation programs in the U.S.: Implications for policy design and outreach. Land Use Policy 29: 53-61.

Maestas, J. D., R. L. Knight, and W. C. Gilgert. 2001. Biodiversity and land use change in the American Mountain West. The Geographical Review 91: 509-524.

McMillan, D. W., and D. M. Chavis. 1986. Sense of community: A definition and theory. Journal of Community Psychology 14: 6-23.

Merenlender, A.M., L. Huntsinger, G. Guthey, and S. K. Fairfax. 2004. Land trusts and conservation easements: Who is conserving what for whom? Conservation Biology 18: $65-75$. 
Mesch, G., and O. Manor. 1998. Social ties, environmental perception and local attachment. Environment and Behavior 30: 504-519.

Miller, A. D., C. T. Bastian, D. M. McLeod, C. M. Keske, and D. L. Hoag. 2010. Factors impacting agricultural landowners' willingness to enter into conservation easements: A case study. Society and Natural Resources 24: 65-74.

Morrisette, P. M. 2001. Conservation easements and the public good: Preserving the environment on private lands. Natural Resources Journal 41: 373-426.

Moscovici, S., and M. Zavalloni. 1969. The group as a polarizer of attitudes. Journal of Personality and Social Psychology 12: 125-135.

Mullendore, N. D., J. D. Ulrich-Schad, and L. S. Prokopy. 2015. U.S. farmers' sense of place and its relation to conservation behavior. Landscape and Urban Planning 140: $67-75$.

Nielsen-Pincus, M., T. Hall, J. E. Force, and J. D. Wulfhorst. 2010. Sociodemographic effects on place bonding. Journal of Environmental Psychology 30: 443-454. 
Nielsen-Pincus, M., P. Sussman, D. Bennett, H. Gosnell, and R. Parker. The influence of sense of place on the willingness to pay for ecosystem services. Ecosystem Services. In review.

Norton, B., and B. Hannon. 1997. Environmental values: A place-based theory. Environmental Ethics 19: 227-245.

Nowak, M. 2012. Landowner consideration of conservation easement utilization in the Adirondack Park of New York. Master of Science Thesis. State University of New York.

Oregon Department for Environmental Quality. 2008. Deschutes River, Whychus Creek and Tumalo Creek Temperature Modeling.

Paulus, W., and A. Orizola. 2015. Oregon conservation easement assessment project: A white paper on conservation easements as a land use tool in Oregon. Portland, OR: Coalition of Oregon Land Trusts.

Peterson, N., D. Speer, and D. McMillan. 2008. Validation of a brief sense of community scale: confirmation of the principal sense of community. Journal of Community Psychology 36: 61-73. 
Petty, R., and J. Krosnick. 1995. Chapter 1: Attitude Strength: An Overview. In Attitude Strength: Antecedents and Consequences. Petty, R., and J. Krosnick, pp. 1-24. 1995. Mahwah, NJ: Lawrence Erlbaum Associates, Inc.

Price, J. C., and Z. Leviston. 2014. Predicting pro-environmental agricultural practices: The social, psychological and contextual influences on land management. Journal of Rural Studies 34: 65-78.

Primmer, E., and H. Karppinen. 2010. Professional judgment in non-industrial private forestry: Forester attitudes and social norms influencing biodiversity conservation. Forest Policy and Economics 12: 136-146.

Proshansky, H. 1978. The city and self-identity. Environment and Behavior 10: 147-169.

Reimer, A. P., A. W. Thompson, and L. S. Prokopy. 2012. The multi-dimensional nature of environmental attitudes among farmers in Indiana: Implications for conservation adoption. Agriculture and Human Values 29: 29-40.

Rogers, E. 2003. Diffusion of Innovations. New York, NY: Free Press.

Relph, E. 1976. Place and Placelessness. London: Pion. 
Rissman, A. R. 2013. Rethinking property rights: comparative analysis of conservation easements for wildlife conservation. Environmental Conservation 40: 222-230.

Schubert, J. R., and A. L. Mayer. 2012. Peer influence of non-industrial private forest owners in the western upper peninsula of Michigan. Open Journal of Forestry 2: $150-158$

Scott, J. M., F. W. Davis, R. G. Mcghie, R. G. Wright, J. Estes, I. F. W. Davis, and C. Groves. 2001. Nature reserves: Do they capture the full range of America's biological diversity? Ecological Applications 11: 999-1007.

Smith, R. 1981. Resolving the tragedy of the commons by creating private property rights in wildlife. Cato Journal 1: 439-468.

Stedman, R. 2002. Toward a social psychology of place: predicting behavior from placebased cognitions, attitude and identity. Environment and Behavior. 34: 561-581.

Tesser, A., L. Martin and M. Mendolia. 1995. Chapter 4: The Impact of Thought on Attitude Extremity and Attitude-Behavior Consistency. In Attitude Strength: Antecedents and Consequences. Petty, R., and J. Krosnick, pp. 73-92. Mahwah, NJ: Lawrence Erlbaum Associates, Inc. 
Thompson, A. W., A. Reimer, and L. S. Prokopy. 2014. Farmers' views of the environment: the influence of competing attitude frames on landscape conservation efforts. Agriculture and Human Values 32: 385-399.

Tuan, Y. 1979. Space and place: humanistic perspective. Philosophy in Geography: 387427.

U.S. Census Bureau. 2013. 2009-2013 5-Year American Community Survey.

Van Fleet, T. E., D. B. Kittredge, B. J. Butler and P. F. Catanzaro. 2012. Reimagining family forest conservation: Estimating landowner awareness and their awareness index. Journal of Forestry 110: 207-215.

Van Gossum, P., S. Luyssaert, I. Serbruyns, and F. Mortier. 2005. Forest groups as support to private forest owners in developing close-to-nature management. Forest Policy and Economics 7: 589-601.

Vaske, J. J., and K. C. Kobrin. 2001. Place attachment and environmentally responsible behavior. The Journal of Environmental Education 32: 16-21. 
Wilcove, J., M. Bean, R. Bonnie, and M. McMillan. 1996. Rebuilding the Ark: Toward a More Effective Endangered Species Act for Private Land. Washington DC: Environmental Defense Fund.

Williams, R. 1977. Marxism and Literature. Oxford: Oxford University Press.

Yung, L., and J.M. Belsky. 2007. Private property rights and community goods: Negotiating landowner cooperation amid changing ownership on the Rocky Mountain Front. Society and Natural Resources 20: 689-703. 
APPENDIX A. Survey Instrument

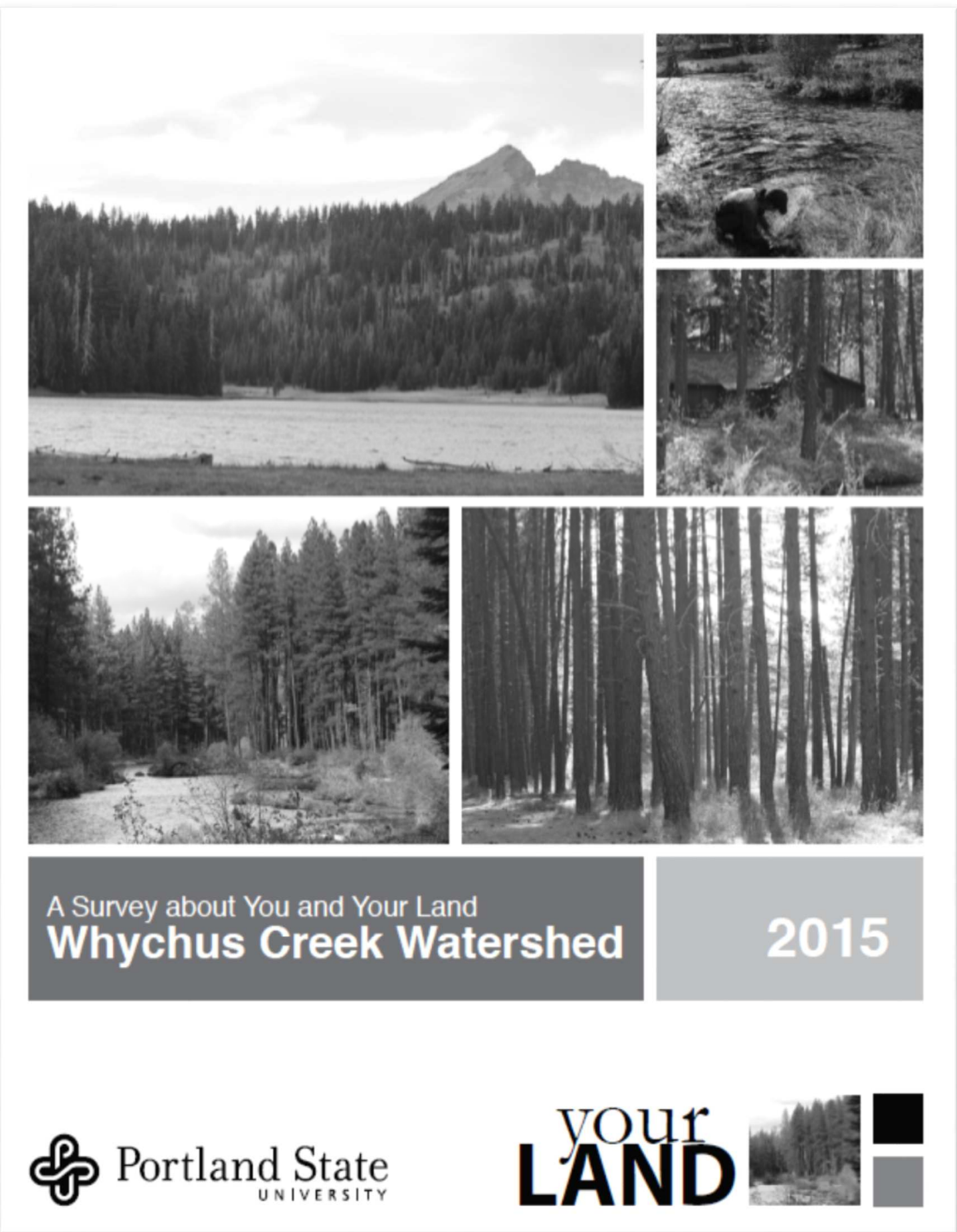




\section{Private Land Conservation}

Portland State University is interested in leaming about your beliefs and attitudes towards select land use and land management behaviors. We think this information is important to help guide the communication of conservation information and strengthen programs focused on private land management to better meet the needs of landowners.

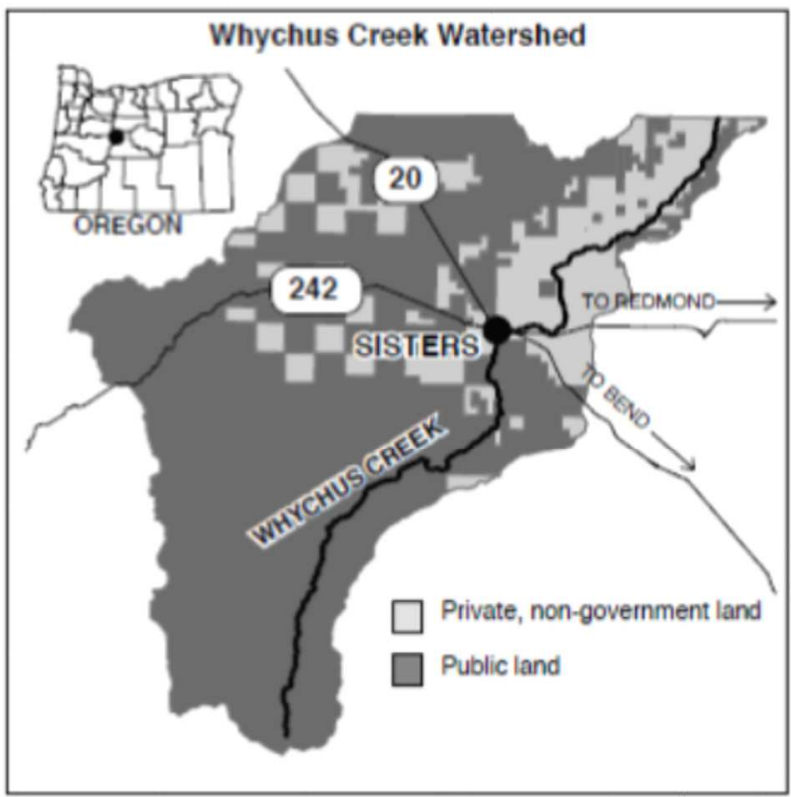

A watershed is an area of land within which all water drains to the same place. In the Whychus Creek Watershed, private land (shown in light gray) surrounds much of the creek north of Sisters. Private land is important as it often provides vital habitat for plant and animal species and also maintains the local culture of a community by supplying open space and scenic views.

Throughout the last few decades there has been an increase in rural growth and development on private land, which is especially evident in Deschutes County. In the past ten years, Deschutes County has experienced the greatest population growth of any county in Oregon.

In order to protect significant attributes of private land, conservation interests, communities and landowners have turned more and more to tools like conservation easements.

A conservation easement is an individually-crafted voluntary legal agreement between a landowner and land trust (a non-profit organization that works to protect land) or government agency, which permanently protects significant conservation values of a piece of land. When a landowner decides to place a conservation easement on their property, they continue to own the property, but the uses of the property that would negatively affect the conservation values are limited.

Conservation easements can protect natural habitats, agricultural or forestry uses as well as scenic views and areas of cultural significance. They are uniquely written to address each landowner's needs and can be applied to the entire property or a portion of it. In some cases, conservation easements provide landowners with a tax benefit. There is no requirement that the landowner allow public access to the property unless the landowner specifically desires to make public access part of the agreement.

We would like to determine if information about conservation easements is widely known. Please help us by answering the following questions about your property as well as your familiarity, knowledge and opinions of conservation easements and select land management practices.

Your responses will be kept confidential 


\section{Survey Instructions}

- Please carefully read each question and make your responses clear

- Feel free to write in additional comments or explanations anywhere on the survey

- All of your answers will be kept confidential

- Please mail your completed survey back in the prepaid envelope provided

\section{Your Land and You}

Approximately how many years have you owned property in the Whychus Creek Watershed?

Approximately how many acres of land do you own in the Whychus Creek Watershed?

What is the current use of the land you own in the Whychus Creek Watershed? Check all that apply.
$\square$ Primary residence
$\square$ Recreation
$\square$ Ranching
$\square$ Farming
Timber/Forestry
Other:

\section{Conservation Easements and You}

We are interested in learning about what you, as a landowner, know and think about the unique land use planning option called a conservation easement.

How much do you know about conservation easements?

Select one response.

Never heard of before reading this questionnaire

Heard of, but know very little

I know a little

I know quite a bit

I know a great deal
6 From whom did you FIRST learn about conservation easements? Select one response.
Never heard of before
I don't remember
Spouse
Producer group
Relative
Professional consultant
Neighbor
Land trust
Soil and water
Extension staff conservation district
Government agency
Other:
Watershed council
Environmental organization

Do you have experience with conservation easements? Select one response.

I have a conservation easement on my land
I have considered a conservation easement for my land
I don't have any experience with conservation easements 
Do you know someone who has experience with conservation easements? Select one response.

Someone I know has a conservation easement on their land someone I know has considered a conservation easement for their land
I don't know of anyone who has experience with conservation easements

8

Do you know of a local land trust?
$\mathrm{O}$ Yes
No

If yes, please list one or two names of land trusts you know of.

Before reading this questionnaire, how aware were you of the following characteristics of conservation easements? Select one response for each.

\begin{tabular}{|c|c|c|c|c|c|}
\hline Conservation easements... & $\begin{array}{l}\text { Very } \\
\text { Aware }\end{array}$ & Aware & $\begin{array}{l}\text { Moderately } \\
\text { Aware }\end{array}$ & $\begin{array}{l}\text { Slightly } \\
\text { Aware }\end{array}$ & $\begin{array}{l}\text { Not At All } \\
\text { Aware }\end{array}$ \\
\hline $\begin{array}{l}\text { Limit the uses of a property (typically } \\
\text { development) that negatively impact } \\
\text { conservation values }\end{array}$ & 0 & O & O & 0 & O \\
\hline $\begin{array}{l}\text { Can be applied to the entire property } \\
\text { or a portion of it }\end{array}$ & 0 & $\cap$ & 0 & $\mathrm{O}$ & 0 \\
\hline Do not require public access & $\mathrm{O}$ & $\mathrm{O}$ & $\mathrm{O}$ & $\mathrm{O}$ & $\mathrm{O}$ \\
\hline $\begin{array}{l}\text { Give the right to monitor and enforce } \\
\text { property restrictions to an eligible entity } \\
\text { such as a land trust }\end{array}$ & 0 & & 0 & O & 0 \\
\hline Are completely voluntary & 0 & $\mathrm{O}$ & 0 & 0 & 0 \\
\hline Keep land in private ownership & 0 & $\mathrm{O}$ & $\mathrm{O}$ & 0 & 0 \\
\hline May provide a financial benefit & 0 & $\mathrm{O}$ & 0 & $\mathrm{O}$ & $\mathrm{O}$ \\
\hline
\end{tabular}

10 Please indicate how much you agree or disagree with the following statements about conservation easements. Select one response for each.

\begin{tabular}{|c|c|c|c|c|c|}
\hline Conservation easements... & $\begin{array}{l}\text { Strongly } \\
\text { Agree }\end{array}$ & Agree & $\begin{array}{l}\text { Neither Agree } \\
\text { nor Disagree }\end{array}$ & Disagree & $\begin{array}{l}\text { Strongly } \\
\text { Disagree }\end{array}$ \\
\hline Protect fish and wildlife habitat & O & 0 & 0 & O & $\Omega$ \\
\hline Enhance local natural resources & $\mathrm{O}$ & & & $\mathrm{O}$ & \\
\hline Allow landowners to leave a legacy & O & & & & \\
\hline $\begin{array}{l}\text { Provide adequate financial incentives for } \\
\text { landowners }\end{array}$ & 0 & & & & \\
\hline Protect land from development & O & D & 0 & O & 0 \\
\hline $\begin{array}{l}\text { Protect the cultural significance of the } \\
\text { lands they are placed on }\end{array}$ & O & & O & $\cap$ & 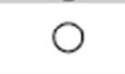 \\
\hline $\begin{array}{l}\text { Protect open space and scenic values } \\
\text { of the lands they are placed on }\end{array}$ & $\Omega$ & $\cap$ & 0 & $\cap$ & $\cap$ \\
\hline Protect agricultural and forestry uses & O & O & O & $\mathrm{O}$ & O \\
\hline Protect and/or enhance stream quality & O & O & O & $\mathrm{O}$ & O \\
\hline
\end{tabular}


11 In general, how much do you agree or disagree with the following statements about placing a conservation easement on your property? Select one response for each.

\begin{tabular}{|c|c|c|c|c|c|}
\hline $\begin{array}{l}\text { Placing a conservation easement } \\
\text { on my property would be... }\end{array}$ & $\begin{array}{l}\text { Strongly } \\
\text { Agree }\end{array}$ & Agree & $\begin{array}{c}\text { Neither Agree } \\
\text { nor Disagree }\end{array}$ & Disagree & $\begin{array}{l}\text { Strongly } \\
\text { Disagree }\end{array}$ \\
\hline Good for fish and wildlife habitat & $\mathrm{O}$ & $\mathrm{O}$ & 0 & & $\mathrm{O}$ \\
\hline Inconvenient for my heirs & O & $\mathrm{O}$ & O & & \\
\hline Useful to protect my land from development & O & O & O & & ) \\
\hline Wise for me financially & $\mathrm{O}$ & $\mathrm{O}$ & $\mathrm{O}$ & $\checkmark$ & $\mathrm{O}$ \\
\hline Easy for me and my family to do & O & 0 & O & & 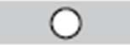 \\
\hline $\begin{array}{l}\text { Incompatible with how I currently } \\
\text { manage my land }\end{array}$ & $\bigcirc$ & $\cap$ & O & & 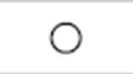 \\
\hline Important for my community & O & $\mathrm{O}$ & O & O & ) \\
\hline Expensive for me and my family & O & $\mathrm{O}$ & 0 & $\mathrm{O}$ & $\mathrm{O}$ \\
\hline
\end{tabular}

12 We asked a few conservation professionals in Oregon to rate the level of risk a landowner may face when placing a conservation easement on their property. Below is a summary of what these experienced people thought.

Rlsk of...

\begin{tabular}{lc}
\hline Future regulatory burdens & VERY LOW \\
\hline Causing difficulty in the future sale of the property & LOW \\
\hline Taking land out of production & VERY LOW \\
\hline Resulting in the loss of privacy & LOW \\
\hline Creating issues with neighboring landowners & LOW \\
\hline Decreasing county property tax revenue & LOW \\
\hline Reducing amount of land in private ownership & VERY LOW \\
\hline
\end{tabular}

A Please indicate the level of risk that you think landowners face when placing a conservation easement on their property. Select one response for each.

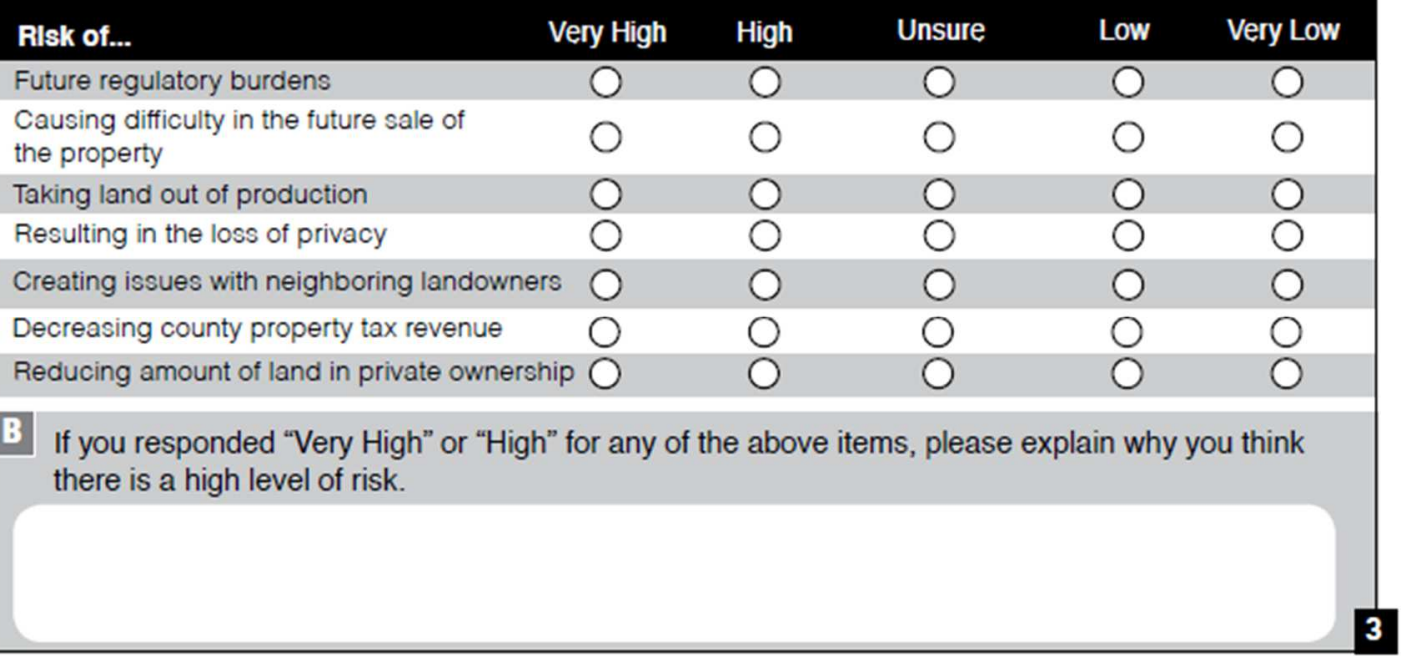


13 In general, how likely or unlikely would you be to place a conservation easement on your property? Select one response.
Very Likely
Likely
Neither Likely nor Unlikely
Unlikely
Very Unlikely

14 Assuming you were considering a conservation easement, how likely or unlikely is it that you would place a conservation easement on your property under the following conditions? Select one response for each.

Very Likely Likely $\begin{gathered}\text { Neither Likely Unlikely Very Unlikely } \\ \text { nor Unlikely }\end{gathered}$

If you had to pay for the costs associated with placing a conservation easement on your property

If there were no financial costs or

benefits to you

If you received a property tax benefit

If you received an estate tax benefit that minimized burden for your heirs

If you received an income tax benefit

If you were paid for the value of the conservation easement

$\bigcirc \quad 0$
nor Unlikely

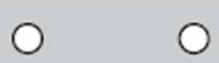

If you were offered property rights

assurances to guarantee no additional

regulatory burdens would arise as a result

of your conservation easement

If you were asked to make a donation to support the land trust's management of the conservation easement

\section{Land Management and You}

We are also interested in learning about your familiarity with select land management practices and behaviors. Your answers will help us understand the current use of land in the watershed.

15 Please check the box on the left if you or someone you know is currently doing any of the following land management practices. Then, for all of the management practices, please indicate your level of experience with that practice on the right.

$\begin{array}{cc}\text { I am currently Someone I know } & \begin{array}{c}\text { No experience I have some I have a lot of } \\ \text { or knowledge experience experience }\end{array}\end{array}$

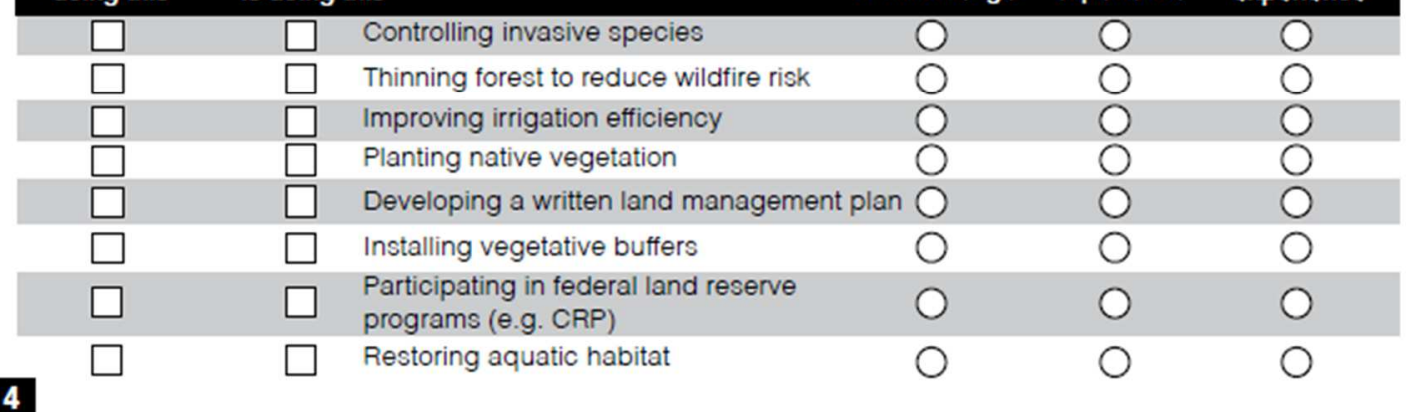


16 In the next five years, how likely or unlikely is it that you would implement the following management practices on your land? Select one response for each.

\begin{tabular}{|c|c|c|c|c|c|}
\hline & Very Likely & Likely & $\begin{array}{l}\text { Neither Likely } \\
\text { nor Unlikely }\end{array}$ & Unlikely & Very Unlikely \\
\hline Control for invasive species & $\mathrm{O}$ & $\mathrm{O}$ & $\mathrm{O}$ & 0 & $\mathrm{O}$ \\
\hline Thin forest to reduce wildfire risk & 0 & 0 & $\mathrm{O}$ & 0 & 0 \\
\hline Improve irrigation efficiency & 0 & 0 & 0 & 0 & 0 \\
\hline Plant native vegetation & $\mathrm{O}$ & 0 & $\mathrm{O}$ & $\mathrm{O}$ & 0 \\
\hline Develop a written land management plan & O & O & $\mathrm{O}$ & $\mathrm{O}$ & 0 \\
\hline Install vegetative buffers & $\mathrm{O}$ & $\mathrm{O}$ & $\mathrm{O}$ & $\mathrm{O}$ & $\mathrm{O}$ \\
\hline Enroll in land reserve program (e.g. CRP) & 0 & 0 & O & $\mathrm{O}$ & 0 \\
\hline Restore aquatic habitat & O & O & $\mathrm{O}$ & $\mathrm{O}$ & $\mathrm{O}$ \\
\hline
\end{tabular}

17 How often do you take part in the following types of behaviors? Select one response for each.

\begin{tabular}{|c|c|c|c|c|c|c|c|}
\hline & Never & Annually & $\begin{array}{c}\text { Every } \\
\text { Few Months }\end{array}$ & Monthly & $\begin{array}{c}\text { Every } \\
\text { Few Weeks }\end{array}$ & Weekly & $\begin{array}{c}\text { More than } \\
\text { Once a Week }\end{array}$ \\
\hline Volunteer with a land trust & 0 & 0 & 0 & 0 & 0 & 0 & 0 \\
\hline $\begin{array}{l}\text { Steward or care for protected } \\
\text { natural areas }\end{array}$ & $\mathrm{O}$ & $\mathrm{O}$ & 0 & 0 & O & $\mathrm{O}$ & $\mathrm{O}$ \\
\hline $\begin{array}{l}\text { Help a neighbor with the } \\
\text { management of their land }\end{array}$ & $\mathrm{O}$ & $\mathrm{O}$ & $\mathrm{O}$ & $\mathrm{O}$ & $\mathrm{O}$ & $\mathrm{O}$ & $\mathrm{O}$ \\
\hline $\begin{array}{l}\text { Work with an organization to } \\
\text { restore your land }\end{array}$ & $\mathrm{O}$ & $\mathrm{O}$ & $\mathrm{O}$ & $\mathrm{O}$ & $\mathrm{O}$ & $\mathrm{O}$ & $\mathrm{O}$ \\
\hline
\end{tabular}

18 When making decisions about your land, how important are the following factors to you? Select one response for each.

\begin{tabular}{|c|c|c|c|c|c|}
\hline & $\begin{array}{l}\text { Very } \\
\text { Important }\end{array}$ & Important & $\begin{array}{l}\text { Moderately } \\
\text { Important }\end{array}$ & $\begin{array}{c}\text { Slightly } \\
\text { Important }\end{array}$ & $\begin{array}{l}\text { Not At All } \\
\text { Important }\end{array}$ \\
\hline $\begin{array}{l}\text { Protecting the open space and scenic } \\
\text { qualities of my property }\end{array}$ & $\mathrm{O}$ & O & $\mathrm{O}$ & $\mathrm{O}$ & $\mathrm{O}$ \\
\hline $\begin{array}{l}\text { Enhancing my community's } \\
\text { natural resources }\end{array}$ & $\mathrm{O}$ & O & O & $\mathrm{O}$ & $\mathrm{O}$ \\
\hline Leaving a legacy for future generations & O & 0 & 0 & O & $\mathrm{O}$ \\
\hline $\begin{array}{l}\text { Providing recreational opportunities for } \\
\text { me and my family }\end{array}$ & O & O & $\mathrm{O}$ & $\mathrm{O}$ & $\bigcirc$ \\
\hline Protecting my property from development & $\mathrm{O}$ & $\mathrm{O}$ & $\mathrm{O}$ & $\mathrm{O}$ & $\mathrm{O}$ \\
\hline Providing income for me and my family & $\mathrm{O}$ & $\mathrm{O}$ & $\mathrm{O}$ & $\mathrm{O}$ & $\mathrm{O}$ \\
\hline $\begin{array}{l}\text { Protecting the cultural significance of my } \\
\text { property }\end{array}$ & O & $\mathrm{O}$ & $\mathrm{O}$ & $\mathrm{O}$ & O \\
\hline Providing a primary residence & O & O & O & $\bigcirc$ & O \\
\hline Protecting fish and wildlife habitat & O & $\mathrm{O}$ & $\mathrm{O}$ & $\mathrm{O}$ & $\mathrm{O}$ \\
\hline Protecting and/or enhancing stream quality & 0 & $\mathrm{O}$ & $\mathrm{O}$ & O & $\mathrm{O}$ \\
\hline
\end{tabular}


19 How supportive or unsupportive are the people in your community of the following land management practices? Select one response for each.

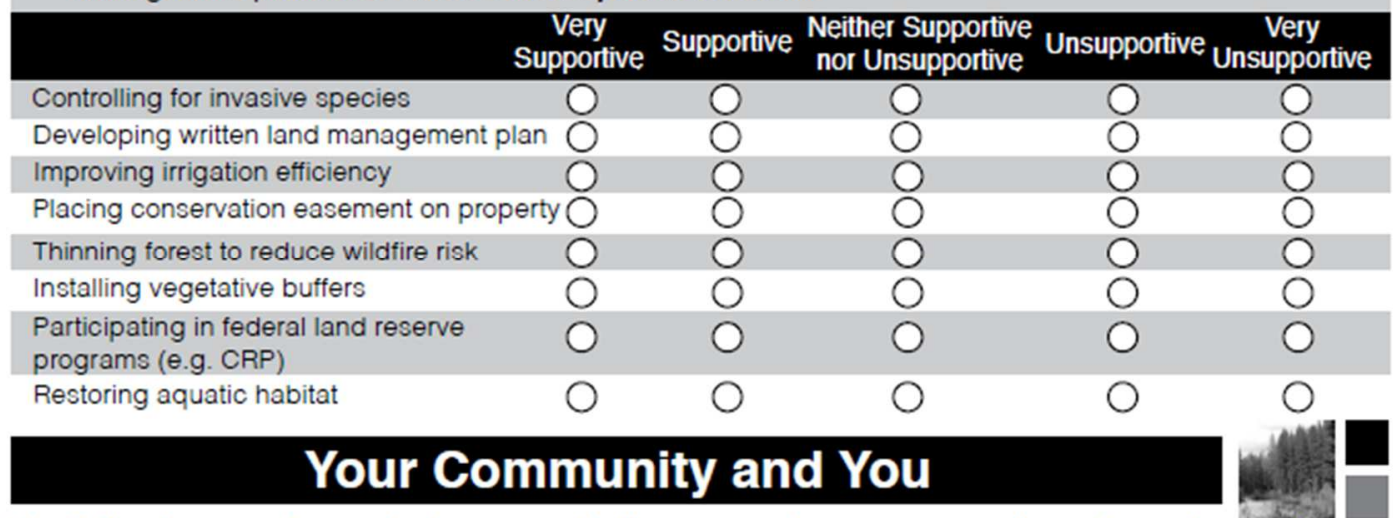

The following questions ask about your feelings towards your community and your interactions with the people in your community. When you are answering these questions, please think about "your community" as specific to you and the interactions you have with people within or in regards to the Whychus Creek Watershed.

20 How attached do you feel to each of the following places? Select one response for each.

\begin{tabular}{|c|c|c|c|c|c|}
\hline & $\begin{array}{l}\text { Extremely } \\
\text { Attached }\end{array}$ & $\begin{array}{c}\text { Very } \\
\text { Attached }\end{array}$ & $\begin{array}{c}\text { Moderately } \\
\text { Attached }\end{array}$ & $\begin{array}{c}\text { Slightly } \\
\text { Attached }\end{array}$ & $\begin{array}{c}\text { Not } \\
\text { Altached }\end{array}$ \\
\hline City of Sisters & 6 & O & 0 & 0 & $\sigma$ \\
\hline Whychus Creek Watershed & ) & O & $\cap$ & D & \\
\hline Upper Deschutes Watershed & & 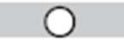 & 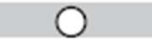 & 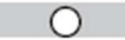 & ) \\
\hline City of Bend & & O & ) & $\mathrm{O}$ & \\
\hline Central Oregon & & $\mathrm{O}$ & & $C$ & \\
\hline Pacific Northwest & & 0 & $\sigma$ & $\Omega$ & 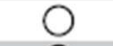 \\
\hline Western U.S. & O & O & 0 & D & ) \\
\hline
\end{tabular}

21 How much do you agree or disagree with the following statements about the importance of the Whychus Creek Watershed to you personally? Select one response for each.

\begin{tabular}{|c|c|c|c|c|c|}
\hline & $\begin{array}{l}\text { Strongly } \\
\text { Agree }\end{array}$ & Agree & $\begin{array}{l}\text { Neither Agree } \\
\text { nor Disagree }\end{array}$ & Disagree & $\begin{array}{c}\text { Strongly } \\
\text { Disagree }\end{array}$ \\
\hline It is my favorite place to be & 0 & 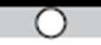 & 0 & O & 5 \\
\hline $\begin{array}{l}\text { As far as I am concerned, there are } \\
\text { better places to be }\end{array}$ & O & & O & O & ) \\
\hline $\begin{array}{l}\text { It is the best place for doing the } \\
\text { things I enjoy }\end{array}$ & 0 & & O & O & \\
\hline $\begin{array}{l}\text { I would enjoy the activites I undertake } \\
\text { there just as well in another place }\end{array}$ & O & & O & O & $\cap$ \\
\hline It reflects the type of person I am & ) & & O & O & 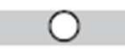 \\
\hline $\begin{array}{l}\text { I feel that I can really be myself when I } \\
\text { am there }\end{array}$ & 0 & & ○ & $\Omega$ & \\
\hline I really miss it when I am away too long & O & O & $\mathrm{O}$ & O & O \\
\hline I feel happiest when I am there & 0 & O & O & O & O \\
\hline $\begin{array}{l}\text { I don't really identify with the Whychus } \\
\text { Creek Watershed }\end{array}$ & O & 2 & $\mathrm{O}$ & O & O \\
\hline
\end{tabular}


How much do you agree or disagree with the following statements about the importance, to you personally, of your community within the Whychus Creek Watershed? Think about "community" as specific to you and the interactions you have with people within the Whychus Creek Watershed. Select one response for each.

\begin{tabular}{|c|c|c|c|c|c|}
\hline & $\begin{array}{c}\text { Strongly } \\
\text { Agree }\end{array}$ & Agree & $\begin{array}{c}\text { Neither Agree } \\
\text { nor Disagree }\end{array}$ & Disagree & $\begin{array}{l}\text { Strongly } \\
\text { Disagree }\end{array}$ \\
\hline I can get what I need in my community & & & & & \\
\hline I feel connected to my community & & & & & \\
\hline I feel like a member of my community & & & & & \\
\hline $\begin{array}{l}\text { I have a good bond with others in my } \\
\text { community }\end{array}$ & 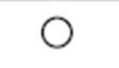 & $\mathrm{O}$ & $\mathrm{O}$ & & \\
\hline $\begin{array}{l}\text { I have a say about what goes on in my } \\
\text { community }\end{array}$ & 0 & D & O & O & \\
\hline $\begin{array}{l}\text { People in my community are good at } \\
\text { influencing each other }\end{array}$ & 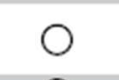 & & O & & \\
\hline My community helps me fulfill my needs & 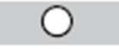 & 0 & 0 & 0 & 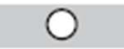 \\
\hline I belong in my community & 0 & $\mathrm{O}$ & $\mathrm{O}$ & 0 & O \\
\hline
\end{tabular}

How often do you talk to your neighbors about the following items? Select one response for each.

\begin{tabular}{|c|c|c|c|c|c|c|c|}
\hline & Never & Annually & $\begin{array}{c}\text { Every } \\
\text { Few Months }\end{array}$ & Monthly & $\begin{array}{c}\text { Every } \\
\text { Few Weeks }\end{array}$ & Weekly & $\begin{array}{c}\text { More than } \\
\text { Once a Week }\end{array}$ \\
\hline $\begin{array}{l}\text { Use or management of your } \\
\text { land }\end{array}$ & $\cap$ & $\cap$ & 0 & 0 & 0 & & O \\
\hline Future plans for your land & $\mathrm{O}$ & O & O & O & $\mathrm{O}$ & O & $\bigcirc$ \\
\hline $\begin{array}{l}\text { Protection of the Whychus Creek } \\
\text { Watershed }\end{array}$ & $\mathrm{O}$ & O & $\mathrm{O}$ & O & O & O & O \\
\hline Land management programs & O & $\mathrm{O}$ & $\cap$ & 0 & $\cap$ & & $\Omega$ \\
\hline Conservation in general & & 0 & 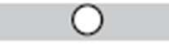 & & & & \\
\hline
\end{tabular}

24 What does neighbor mean to you? Select the best response or provide your own definition in the box following "Other."

Only the people that live on the land next to me

People that live next to me, but also people a

People that live in the same general few houses down

People who live within a mile of me

People who live within two miles of me

$$
\text { community as me }
$$

Other:

How often do you take note of how your neighbor manages their land? Select one response.
Never
Rarely
Sometimes
Often
All the time

26 How often have you specifically done something because of your neighbor's success with it? Select one response.
O Never
Rarely
Sometimes
Often
All the time

27 How often have you specifically avoided doing something because of your neighbor's failure with it? Select one response.
Never
Rarely
Sometimes
Often
All the time 


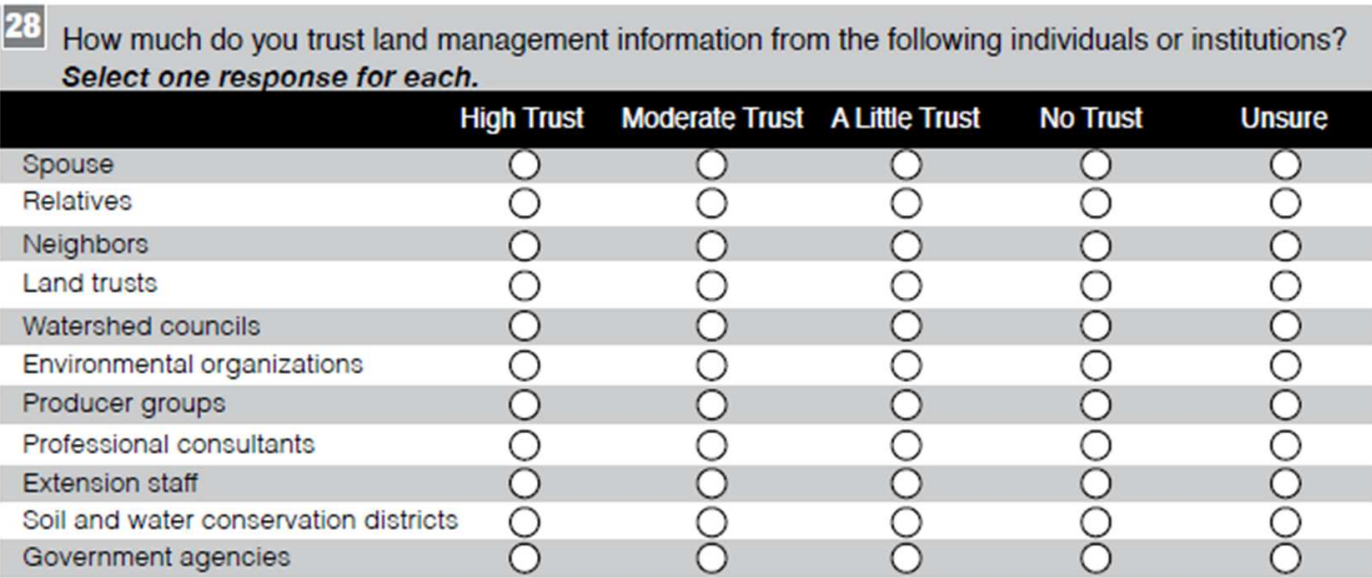

When you are struggling with a difficult question or problem related to managing your land, please list the 3 or 4 people whose opinion you most respect. Please only list their first name and identify their affiliation or relation to you. Example 1: John, Deschutes Soil and Water Conservation District. Example 2: Mary, Wife.
Name
Affiliation

1.

2.

30 Have you ever received land management or conservation information from the following individuals or institutions?

\section{Chock all that apply.}

Spouse

Relative

Neighbor

Land trust

Soil and water conservation district

Watershed council

Government agency

$\square$ Producer group
$\square$ Professional
consultant
$\square$ Extension staff
$\square$ Environmental
organization

3.

4.

\section{Name}

Affiliation

31 Whose opinion do you think you would be most likely to follow when making a land management or conservation decision? Select one response.
Spouse
Producer group
Neighbor
Professional consultant
Relative
Land trust
Soil and water
Extension staff
organization conservation district $\bigcirc$ Government agency

Watershed council

\section{More About You}

Please tell us a little bit more about yourself. Remember, your responses are confidential.

Approximately how many months of the year do you live in the Whychus Creek Watershed?
Less than 4 months
4-9 months
More than 9 months 
What is the highest level of education that you have completed? Select one response.

$O$ Less than a high school degree

High school degree or GED

Some college

34 In the foreseeable future, do you anticipate that you will continue to own your property in the Whychus Creek Watershed?
OYes
ONo
Unsure

2 year college degree

4 year college degree

Advanced degree (Masters, J.D., M.D., Ph.D.)

37 Please rate whether you consider your political views to be more conservative or more liberal. Select one response.
O Very Conservative
Somewhat
Conservative
Neither Conservative nor Liberal
Somewhat
Liberal
O Very
38 Which of the following best describes your household's 2014 pre-tax annual income? Select one response.
Less than $\$ 15,000$
O $\$ 35,000-\$ 49,999$
$\$ 100,000-\$ 149,999$
O $\$ 15,000-\$ 24,999$
O $\$ 50,000-\$ 74,999$
\$150,000- $\$ 199,999$
O $\$ 25,000-\$ 34,999$
○ $\$ 75,000-\$ 99,999$
O $\$ 200,000$ or more

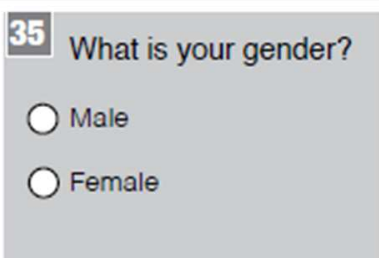

36 In what year were you born?

If you would like, please use the space below and on the back cover to write any other opinions or thoughts you may have about topics covered in this questionnaire (optional): 


\section{Summary Report}

A Survey About You and Your Land: Whychus Creek Watershed Private Landowner Attitudes and Interest in Conservation Easements

\section{January 2016}

\section{Ashley Vizek}

Environmental Science and Management

Portland State University

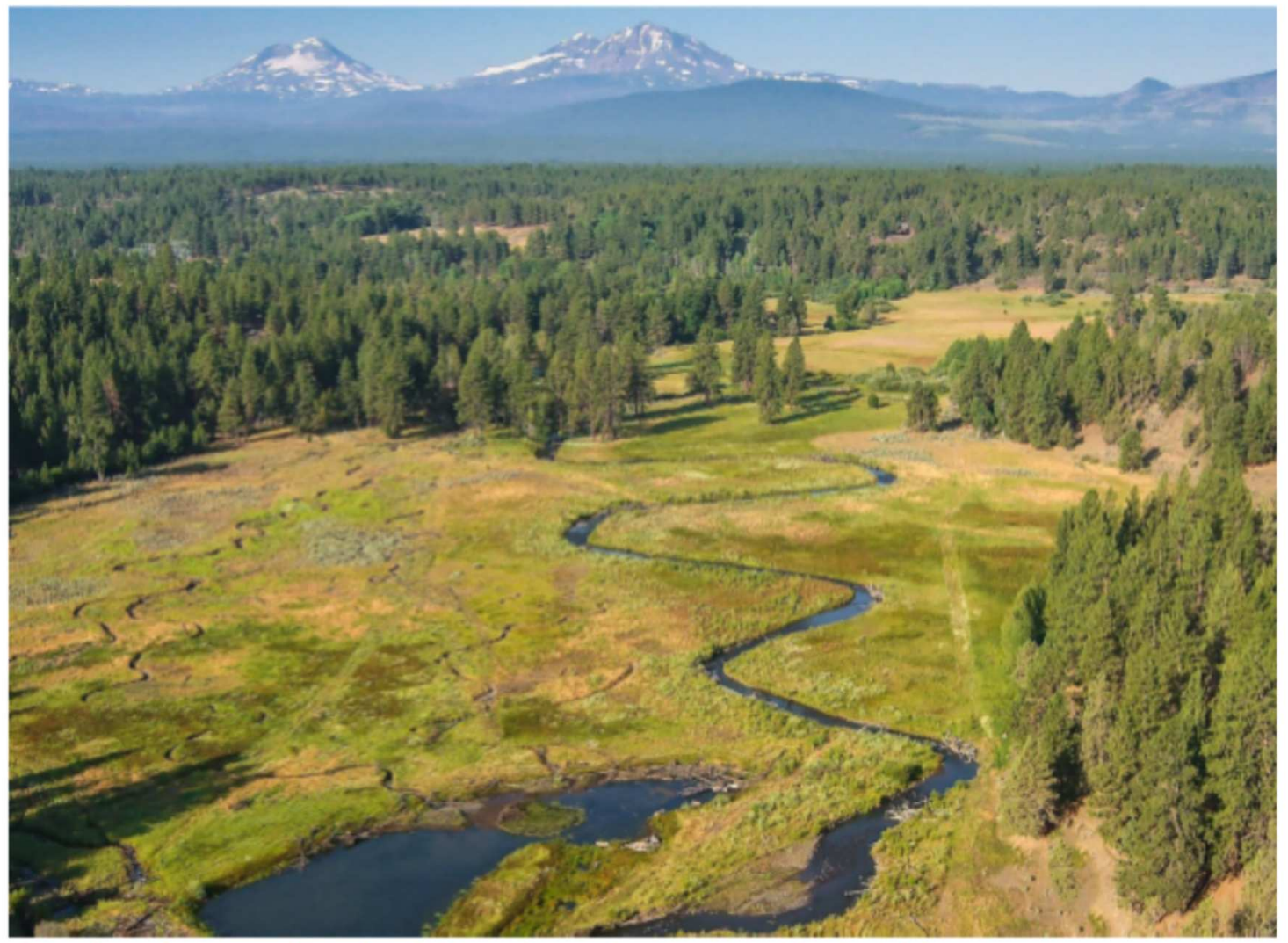

Whychus Creek ar Deschuses Land Trusr's Camp Pokk Meadow Preserve. Photo: Deschutes Land TrustiRuss Lacluelan

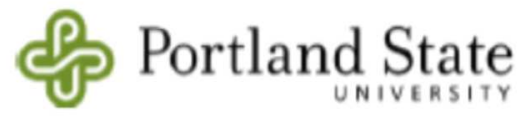


This report was prepared by Ashley Vizek, a graduate student at Portland State University, advised by Max Nielsen-Pincus, PhD, Assistant Professor at Portland State University.

Cover photograph provided by Deschutes Land Trust/Russ McMillan.

Funding for the survey was provided by the Edward D. and Olive C. Bushby Scholarship and the Nielsen-Pincus Natural Resources Policy and Management Lab. I appreciate their support in this project.

I am very grateful to the many people that helped develop, edit and review the survey instrument. 
Dear Survey Respondents,

I would like to express my gratitude for your time in responding to my survey. Thank you for taking an interest in this research project and for sharing your opinions. I am conducting this project as part of my thesis, thus I am personally grateful to you in helping me towards my goal of obtaining a graduate degree.

As of November 1, 2015, I received 257 responses both through the mail and online. Each and every one of these responses is important in helping me to address the research objectives of my project. I valued the experience of reading through each response and entering the data as it provided an opportunity to connect with the respondent. I appreciated the opportunity to leam about each unique perspective.

In order to maintain confidentiality, the report that follows is a preliminary data summary of your responses. Although this report may not present each individual and unique story, it does weave together a larger perspective composed of many different landowners.

I am extremely grateful to you for participating in this survey. The survey was lengthy and detailed, and I sincerely appreciate you taking the time to share your perspective. I hope the following report will be interesting to you.

Sincerely,

Asilleg Viret

M.S. Graduate Student 


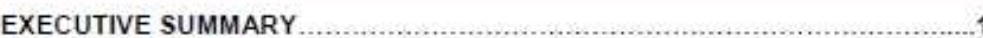

SECTION ONE | Introduction .............................................................

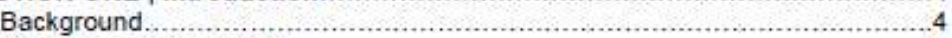

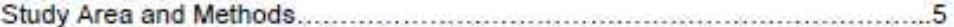

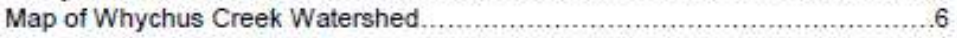

Organization of this Report

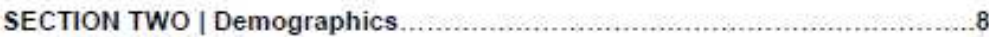

Age and Gender.

Property in the Whychus Creek Watershed ..........................................

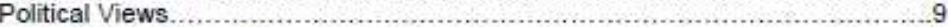

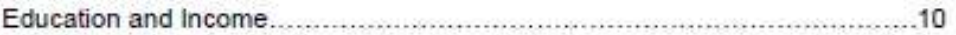

SECTION THREE | Conservation Easements and You.................................11

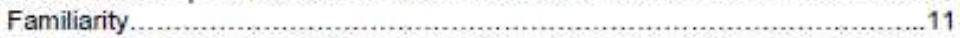

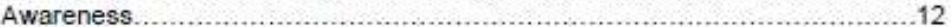

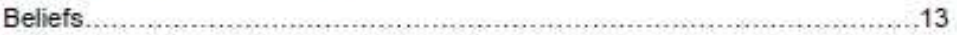

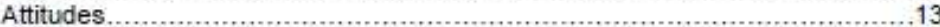

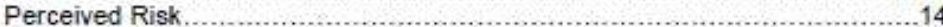

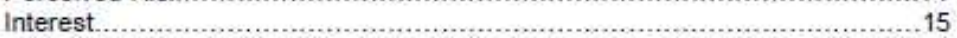

SECTION FOUR | Land Management and You...................................17

Land Management Practices.............................................................. 17

Important Factors in Land Management Decisions ...................................19

Community Support for Land Management Practices................................20

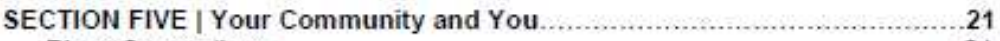

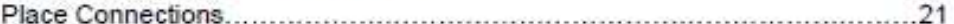

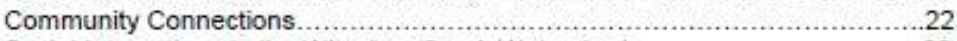

Social Interactions in the Whychus Creek Watershed ................................23

SECTION SIX | Response Comparisons ..............................................

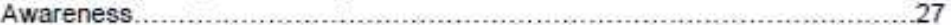

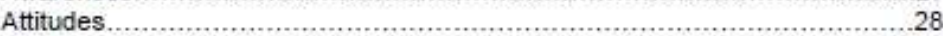

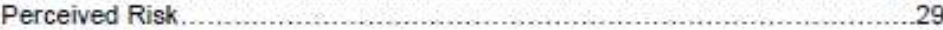

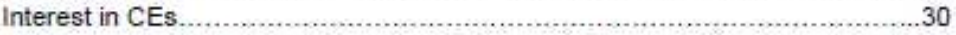

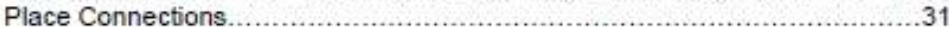

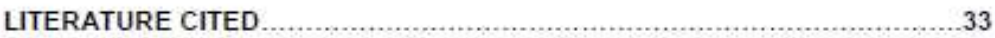


Private land provides valuable ecological and cultural resources while also supplying open space and scenic views. Unfortunately, private land is vulnerable to development and subdivision, presenting a need to conserve our remaining private lands. Conservation easements (CEs) emerged in the 1980 s as a popular approach to private land conservation. $A C E$ is a legal agreement between a landowner and an eligible organization, such as a land trust or government agency. This agreement is tailored to meet both the goals of the conservation organization and the landowner. CEs are powerful voluntary conservation tools that allow land to remain in private ownership. CEs, and private land conservation in general, are dependent on the decisions of private landowners; therefore, it is necessary to gain a better understanding of the factors impacting a landowner's decision to place a CE on their property.

My thesis research at Portland State University explores landowner perceptions of CEs focusing on how information, attitudes, social interactions and place connections influence private land conservation actions. In order to address these questions, 1 distributed a questionnaire to private landowners in the Whychus Creek Watershed (Deschutes County, Oregon) during the summer of 2015 . The questionnaire asked about landowners' interest in conserving the natural qualities of their land through the use of CEs and select land management practices.

As of November 1, 2015 I received 257 responses, yielding a response rate of $41 \%$. Survey respondents were older than 50 years of age and, in comparison to the general population, had a higher level of education and above-average income. Most survey respondents specified that they use their property as a primary residence and live on their property more than nine months out the year. There was a wide range of property sizes ranging from less than one acre to greater than 2,000 acres. The report that follows summarizes the survey responses from this sample of landowners.

Additionally, this report includes an exploration of the differences between respondents who were likely, unlikely or unsure about placing a CE on their property ${ }^{1}$. Survey respondents who said they were Likely or Very Likely formed the Yes Group $(n=43)$, those that said Neither Likely nor Unlikely formed the Maybe Group $(n=95)$ and those that said Unfikely or Very Unlikely formed the No Group $(n=119)$.

${ }^{1}$ Respondents were categorized into three groups based on their response to Q13 of the survey-In general, how fikely or unlikely would you be to place a conservation easement on your property? 


\section{Key Findings}

Place Connections I When asked about how they connected to the Whychus Creek Watershed, more respondents had a positive connection than a negative connection. Respondents reported a high emotional connection to the Watershed as well as high self-identification to the Watershed. Conversely, respondents reported a lower level of behavioral dependence on the Watershed. Respondents in the Yes Group were more positively connected to the Watershed than respondents in the No and Maybe Groups. Consistent with past research, this suggests that there may be a link between sense of place and likelihood of adopting a CE (Cross et al. 2011, Vaske and Kobrin 2010). Respondents also had a positive connection to their social community in the Whychus Creek Watershed. They reported high levels of membership and emotional connection to their community, but reported much lower levels of having an influence in their community.

Awareness of CEs | Survey respondents were moderately aware of CEs; over $60 \%$ of respondents said they knew at least a little about CEs. Respondents in the Yes Group showed the highest levels of awareness, whereas the Maybe Group showed the lowest levels of awareness. Awareness of CEs may be a limiting factor for landowners in the Maybe Group.

Beliefs about CEs and Attitudes towards CEs | In general, survey respondents held positive beliefs about the characteristics of CEs. However, the majority of respondents were unsure if CEs provide adequate financial incentives. Most survey respondents expressed neutral attitudes towards CEs. The Yes Group held the most positive attitudes towards CEs, while the No Group held the most negative attitudes.

Information Sources | The top five sources that respondents received land management information from included 1) land trusts, 2) government agencies, 3) neighbors, 4) environmental organizations and 5) soil and water conservation districts. Landowners were also asked how much they trusted land management information from these various institutions and individuals. The top five highly trusted information sources included 1) spouse, 2) land trusts, 3) watershed councils, 4) relatives and 5) environmental organizations. When asked who were the three or four individuals or institutions whose opinion they would most respect when struggling with a difficult land management problem, $21 \%$ of the responses were neighbors, $17 \%$ were spouses, $17 \%$ were affiliated with a government agency and $10 \%$ were friends. However, when asked to list the one opinion they would be most likely to follow the top three included 1) spouse, 2) land trusts and 3) professional consultants.

Perceived Risk and Advantages of CEs | Survey respondents rated future regulatory burdens and causing difficulty in the future sale of a property as the largest risks associated with CEs. However, those risks 
appeared to be outweighed by a number of potential benefits. When asked how likely or unlikely they were to place a CE on their property in general, $13 \%$ reported that they were Likely or Very Likely. The percentage of respondents who were Likely or Very Likely to place a CE on their property increased from $13 \%$ to approximately $50 \%$ if they were offered 1) a property tax benefit, 2) an estate tax benefit, 3 ) property rights assurances to guarantee no additional burden would arise as a result of the CE or 4) paid the value of the $C E$. The overall percentage of respondents who were Likely or Very Likely did not change if there were no financial costs or benefits to the landowner or if the landowner was asked to make a donation to support the land trust's management of the $C E$. 
Land protection in the United States has historically been achieved through the outright acquisition of land by public agencies. While public reserves provide varying levels of protection from land use change, these reserves may not protect the land with the greatest biodiversity. Preferred habitat for between $90-95 \%$ of federally threatened and endangered species is on private land (Scott et al. 2001). Despite the ecological importance of private land, there has been a dramatic increase in development on private land (Brown et al. 2005). Rural and low-density communities near public natural areas have become an appealing option for development as people seek quality-of-life and outdoor recreational opportunities (Maestas et al. 2001), presenting an urgency to incorporate private lands in natural area conservation.

In the 1980 s, conservation easements (CEs), although not a new idea, emerged as an innovative method of protecting private land. CEs are attached to the property deed, meaning that significant conservation values of a piece of land can be permanently protected. A CE is an individuallycrafted voluntary legal agreement between a landowner and land trust (a non-profit organization that works to protect land) or government agency. When a landowner decides to place a CE on their property, they continue to own the property, but uses and/or management practices that would negatively affect the conservation values are limited or prohibited. CEs are now a popular tool used by land trusts across the U.S. to protect habitat, agricultural and forestry uses, biodiversity and open space (Kiesecker et al. 2007).

For my M.S. thesis research I was interested in exploring private landowners' awareness of and attitudes towards CEs to better understand how CEs can be further utilized in private land conservation. This research project focused on one study area-the Whychus Creek Watershed in Deschutes County, Oregon. The objectives of this research project were to:

- Determine private landowners ${ }^{1}$ familiarity with and attitudes towards CEs;

- Understand the advantages and risk that landowners perceive to be associated with CEs;

- Evaluate the role of community and social connections in developing an awareness of and interest in CEs:

- Identify private landowners' likelihood of placing a CE on their property.

This report summarizes responses to the questionnaire titled "A Survey About You and Your Land: Whychus Creek Watershed" implemented to address the research objectives presented above. 


\section{Study Area and Methods}

Whychus Creek (Deschutes County, Oregon) provided an appropriate and interesting study area to investigate my research objectives for two primary reasons: 1) private land conservation is particularly relevant in this area due to the ownership pattern of private land surrounded by public land (Figure 1.1) and 2) there is an extensive history of conservation and restoration efforts in the area.

Deschutes County has been experiencing increases in population and is one of the fastest growing counties in Oregon. The area surrounding Whychus Creek may be especially vuinerable to increases in development as the area is situated between public protected land, offering outdoor recreational opportunities, and Whychus Creek, an attractive and valuable quality-of-life resource. Therefore, private land conservation is a useful tool in the Whychus Creek area as it maintains land in private ownership while also protecting valuable ecological resources. Additionally, Whychus Creek presents an interesting case study due to the presence of well-developed conservation interests in the area, exemplified through an extensive history of conservation and restoration activity. Interest in restoring Whychus Creek gained momentum in the 1990 s when many private and public entities began collaborating to restore aquatic and terrestrial habitat in order to address water allocation issues and potential federal regulation under the Endangered Species Act. This initial effort has developed into an established suite of private organizations, public agencies and landowners who continue to conserve and restore Whychus Creek.

The boundaries of the study area used in this research project reflect the boundaries of the Whychus Creek Watershed. A watershed can be defined as an area of land within which all water drains to the same place. Therefore, by using the watershed boundaries to delineate the study area each parcel of land within the study area is connected to Whychus Creek. I randomly selected a sample of private landowners within the Whychus Creek Watershed based on a few criteria, which included that:

- Landowners were private individuals, trusts or family businesses; not industrial or corporate landowners;

- Landowners owned more than five acres, unless they owned property directly adjacent to the creek or next to property that had been previously protected.

Participants were recruited using the Tailored Design Method (Dillman 2000), which consisted of a four contact mailing approach offering both a web and paper survey instrument. Mailings were administered between July and September 2015. As of November 1, 2015 I received 257 responses yielding a response rate of $41 \%$. 


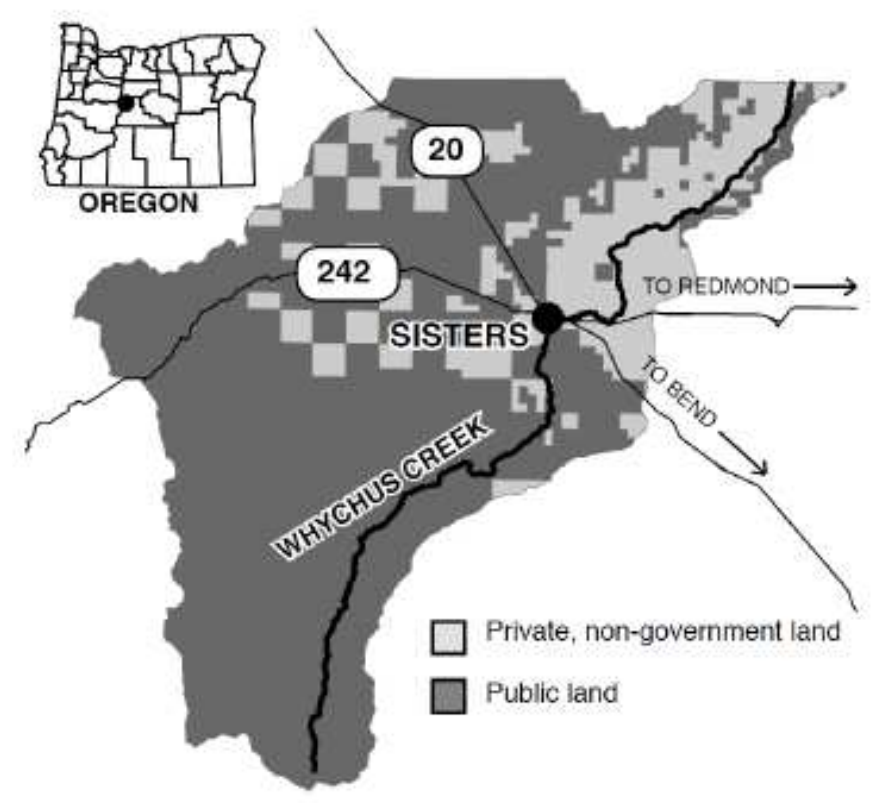

Figure 1.1 Map of the Whychus Creek Watershed

\section{Organization of this Report}

The remainder of this report presents a summary of the survey results, based on the 257 responses received as of November 1, 2015. The report is organized into four main sections, reflecting the structure of the questionnaire. Each section of the report includes a written summary of the responses and, where appropriate, a descriptive table and graph. Each of the graphs presented in Section Three, Four and Five show the cumulative percentage of positive, neutral and negative responses ${ }^{t}$.

- Section Two describes demographic characteristics of the survey respondents in comparison to the general population in the Whychus Creek Watershed.

${ }^{1}$ For example, if a survey question asked a respondent to rate how much they agree or disagree with a statement on the five point scale of Strongly Agree to Strongly Disagree, the graph would show the percentage of respondents who agreed (grouping Strongly Agree and Agree responses), neither agreed nor disagreed and those who disagreed (grouping Strongly Disagree and Disagree responses). 
- Section Three summarizes responses to questions in the Conservation Easements and You section of the survey. These questions asked respondents about their familiarity, beliefs and attitudes towards CEs. In this section, respondents were also asked how likely they were to place a CE on their property in general and under specific situations.

- Section Four summarizes responses to questions in the Land Management and You section of the survey. These questions asked respondents about their experience with select land management practices and their likelihood to implement these practices on their property.

- Section Five summarizes responses to questions in the Your Community and You section of the survey. These questions asked respondents about their connection to the social community and physical environment of the Whychus Creek Watershed.

- Section Six presents a more in-depth analysis and interpretation of the survey responses by comparing different groups of landowners based on their likelihood of placing a CE on their property. This section does not follow a question-by-question format as the previous sections, but instead highlights the key findings.

An index of figures and tables can be found in Appendix A. Appendix B contains a copy of the survey titled, "A Survey About You and Your Land: Whychus Creek Watershed" for reference. Within the sections above I note which question you should refer to for original question wording and formatting. 
In this section I describe the general characteristics of survey respondents based on their responses to questions in the Your Land and You and More About You section of the survey. Survey question numbers are listed in figure captions and can be referenced in Appendix B.

Additionally, to understand areas of potential bias I compared, where possible, demographics of respondents to U.S. Census Data. I used U.S, Census Data from the 2013 American Community Survey for the census blocks that composed the Whychus Creek Watershed, excluding the City of Sisters. I was unable to specify the U.S. Census Data for only private landowners, thus, I expected there to be some differences between the survey respondents and the U.S. Census Data.

\section{Age and Gender}

Q36. The average age of survey respondents was 64.5 years $(n=221)$. Figure 2.1 shows the percentage of survey respondents within each age group compared to the general population in the Whychus Creek

Watershed based on the U.S. Census Data. Respondents younger than 40 were not represented and the age groups between 60 and 79 were overrepresented. While survey respondents were older than the general population, this is not unprecedented. The National Woodland Owner Survey found a similar age distribution, where most family forest owners were older than 45 (Butler 2006).

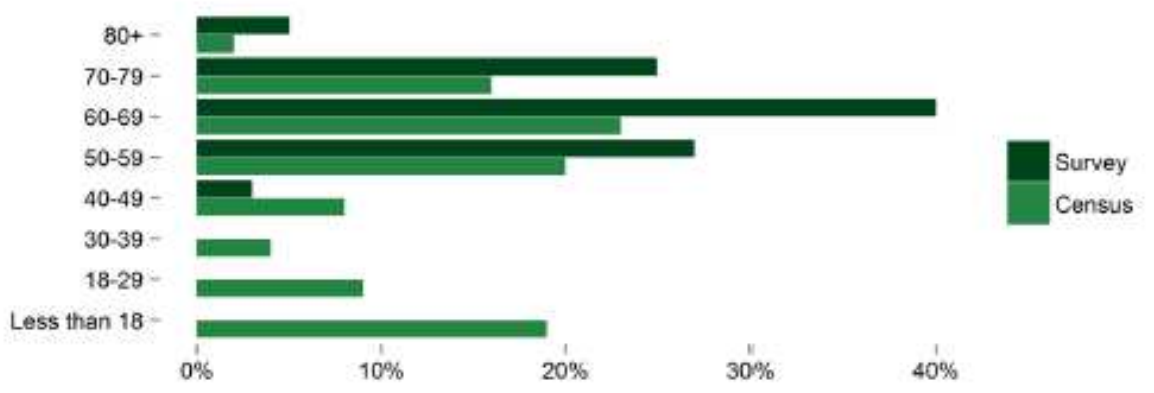

Figure 2.1 [Q36] Age of survey respondents and the general population of the Whychus Creek Watershed ( $n=221$ ) 
Q35. Males accounted for $62 \%$ of the respondents, whereas, females accounted for $38 \%$ of the respondents ( $n=235$ ). In comparison, the general population in the Whychus Creek Watershed was comprised of $53 \%$ males and $47 \%$ females. The gender distribution of survey respondents is consistent with other surveys of private landowners, such as the National Woodland Owner Survey (Butler 2006).

\section{Property in the Whychus Creek Watershed}

Q1. The average number of years that survey respondents have owned property in the Watershed was 18.3 years $(n=256)$. The length of ownership ranged from less than one year to 65 years and the median length of ownership in the Watershed was 15 years.

Q2. Respondents' average property size was 39.1 acres ( $n=257$ ). Acreage owned by survey respondents ranged from less than one acre to over 2,000 acres and the median property size was ten acres.

Q32. Most respondents (68\%) specified that they live on their property for more than nine months out of the year; $9 \%$ live on their property between four and nine months and $28 \%$ live on their property less than four months out of the year $(n=240)$.

Q3. Most respondents (69\%) reported that they use their property for a primary residence (Figure 2.2); $21 \%$ use their property for recreational uses; $16 \%$ for "other" uses which included investment purposes and future development; $13 \%$ use their property for timber or forestry purposes; $9 \%$ use their property as a second home or vacation property; $8 \%$ use their property for ranching and $6 \%$ use their property for farming.

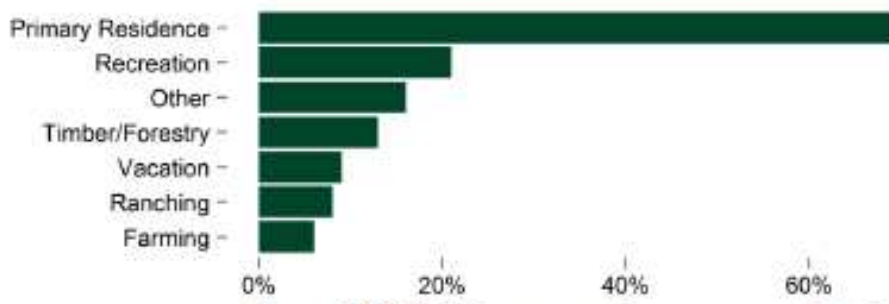

Figure 2.2 [Q3] Primary use of survey respondents' property ( $n=257)$

\section{Political Views}

Q37. Political views were evenly distributed across conservative and liberal perspectives $(n=228)$. Many survey respondents $(31 \%)$ considered their political viewpoints to be Somewhat Conservative, while $10 \%$ reported Very Conservative political views. $26 \%$ of respondents reported Somewhat Liberal political views and $15 \%$ reported Very Liberal political views. $18 \%$ reported that their views were Neither Conservative nor Liberal. 


\section{Education and Income}

Q33. The survey sample is most representative of a highly educated population of landowners as the majority of respondents reported obtaining at least a four year college degree. Figure 2.3 shows the highest level of education completed by survey respondents $(n=238$ ) in comparison to the general population in the Whychus Creek Watershed. Education levels below a two year college degree were underrepresented in comparison to the general population.

Advanced degree

Four year college degree -

Two year college degree -

Some college -

High school degree -

Less than high school -
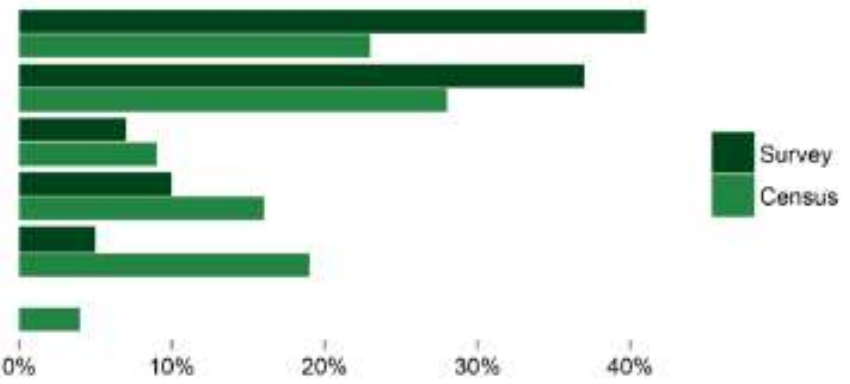

Figure 2.3 [Q33] Highest level of education completed by survey participants and the general population of the Whychus Creek Watershed $(n=238)$

Q38. Figure 2.4 shows the income distribution of survey respondents $(n=203$ ) in comparison to the general population in the Whychus Creek Watershed. Many survey respondents $(26 \%)$ reported an annual household income of more than $\$ 200,000$ for 2014 . The income range with the next highest percentage of respondents $(25 \%)$ was between $\$ 100,000$ and $\$ 149,999$. Income ranges below $\$ 75,000$ were not well-represented by the survey. The National Woodland Owner Survey also found that landowners were wealthier than the general population (Butler 2006).

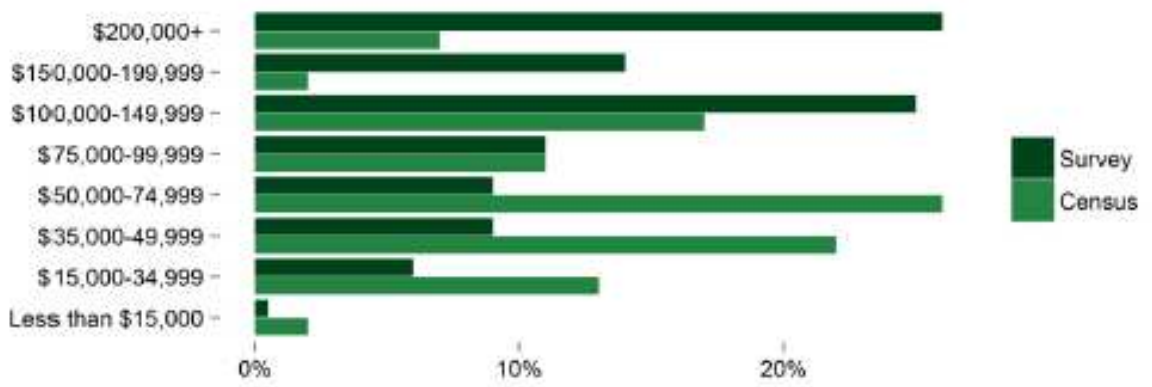

Figure 2.4 [Q38] Survey respondents' household income in comparison to the general Whychus Creek Watershed population $(n=203)$ 


\section{Conservation Easements and You}

This section summarizes the responses to questions in the Conservation Easements and You section of the survey. These questions asked respondents about their familiarity with and awareness of conservation easements (CEs). Additionally, respondents were asked about their beliefs and attitudes towards CEs. This section also contained questions about the amount of risk respondents perceived to be associated with CEs and respondents' likelihood of placing a CE on their property.

\section{Familiarity with Conservation Easements}

Q4. How much do you know about conservation easements? $(n=255)$

- $15 \%$ of respondents had never heard of a CE before reading the questionnaire

- $23 \%$ heard of a CE, but know very little

- $37 \%$ of respondents know a little about CEs

- $20 \%$ know quite a bit about CEs

- $5 \%$ know a great deal about CEs

Q5. From whom did you FIRST learn about conservation easements? Select one response. $(n=255)$

The top five responses included 1) land trust $(26 \%), 2)$ other $(21 \%)$, of which the most common description was "media/newspaper", 3) don't remember $(19 \%), 4)$ never heard of before reading this survey $(16 \%)$ and 5) neighbor (6\%).

Q6-7. Do you have experience with conservation easements? Do you know someone who has experience with conservation easements? Select one response. $(n=248)$

$17 \%$ had either considered or completed a CE (Table 3.1). The majority of respondents specified that they do not know anyone who has experience with CEs ( $62 \%$ ), while $38 \%$ responded that they know someone who has considered or completed a CE.

Table 3.1 [Q6-7] Personal and indirect experience with conservation easements ( $n=248$ )

\begin{tabular}{lccc}
\hline & No Experience & Considered CE & Completed CE \\
\hline Q6. Perconal Experience & $83 \%$ & $11 \%$ & $6 \%$ \\
Q7. Indirect Experience & $62 \%$ & $7 \%$ & $31 \%$ \\
\hline
\end{tabular}


Q8. Do you know of a local land trust? If yes, please list one or two names of the land trusts you know of. $(n=250)$

- $20 \%$ of respondents did not know of a local land trust

- $16 \%$ knew of a local land trust, but did not provide a name

- $4 \%$ knew of a local land trust, but listed only a partially correct name

- $60 \%$ of respondents knew of a local land trust and listed an accurate name (the most frequently fisted name was the "Deschutes Land Trust")

\section{Awareness of Conservation Easements}

Q9. Before reading this questionnaire, how aware were you of the following characteristics of conservation easements? Select one response for each.

Respondents were most aware that CEs 1) limit the use of the property they are placed on, 2) are voluntary and 3) keep land in private ownership (Table 3.2, Figure 3.1). Respondents showed low levels of awareness that CEs 1) do not require public access, 2) give the right to monitor and enforce property restrictions to an eligible entity and 3 ) may provide a financial benefit.

Table 3.2 [Q9] Awareness of the characteristics of conservation easements ( $n=245-249)$

\begin{tabular}{|c|c|c|c|c|c|c|}
\hline Conservation easements... & $\begin{array}{l}\text { Very } \\
\text { Aware }\end{array}$ & Aware & $\begin{array}{c}\text { Moderately } \\
\text { Aware }\end{array}$ & $\begin{array}{l}\text { Slightly } \\
\text { Aware }\end{array}$ & $\begin{array}{l}\text { Not At All } \\
\text { Aware }\end{array}$ & n \\
\hline $\begin{array}{l}\text { Limit Uses: Limit the uses of a property (typically } \\
\text { development) that negatively impact conservation values }\end{array}$ & $29 \%$ & $26 \%$ & $15 \%$ & $12 \%$ & $18 \%$ & 249 \\
\hline Voluntary: Are completely voluntary & $26 \%$ & $29 \%$ & $9 \%$ & $10 \%$ & $26 \%$ & 245 \\
\hline Private Ownership: Keep land in private ownership & $22 \%$ & $31 \%$ & $12 \%$ & $9 \%$ & $26 \%$ & 246 \\
\hline $\begin{array}{l}\text { Size: Can be applied to the enfire property or a portion } \\
\text { of it }\end{array}$ & $18 \%$ & $26 \%$ & $17 \%$ & $10 \%$ & $29 \%$ & 249 \\
\hline Financial Incentives: May provide a financial benefit & $15 \%$ & $14 \%$ & $13 \%$ & $12 \%$ & $46 \%$ & 248 \\
\hline $\begin{array}{l}\text { Property Rights: Give the right to monitor and enforce } \\
\text { property restrictions to an eligible entity such as a land } \\
\text { trust }\end{array}$ & $13 \%$ & $24 \%$ & $19 \%$ & $15 \%$ & $29 \%$ & 248 \\
\hline Public Access: Do not require public access & $12 \%$ & $25 \%$ & $17 \%$ & $11 \%$ & $35 \%$ & 246 \\
\hline
\end{tabular}

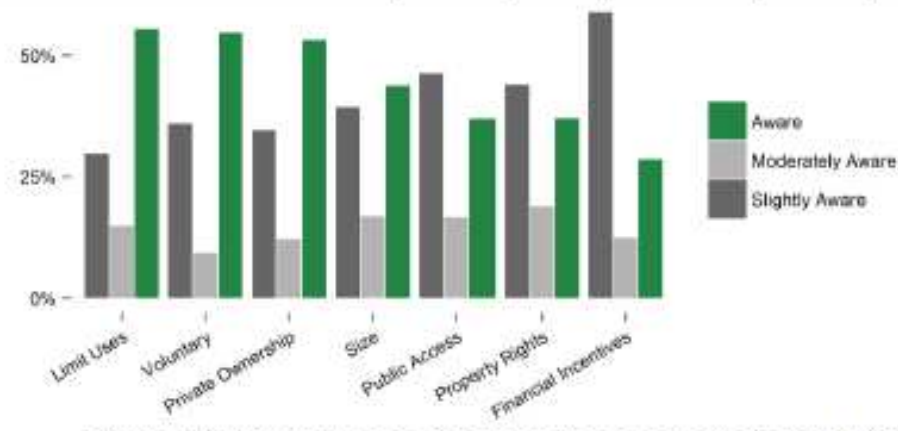

Figure 3.1 [Q9] Awareness of conservation easements ( $n=245-249)$ 


\section{Beliefs about Conservation Easements}

Q10. Please indicate how much you agree or disagree with the following statements about conservation easements. Select one response for each.

In general, respondents agreed with all the statements about CEs (Figure 3.2, Table 3.3). The items which respondents agreed with the least included 1) provide an adequate financial incentive, 2) protect the cultural value of the lands they are placed on and 3 ) protect agricultural and forestry uses.

Table 3.3 [Q10] Beliefs about conservation easements ( $n=243-245)$

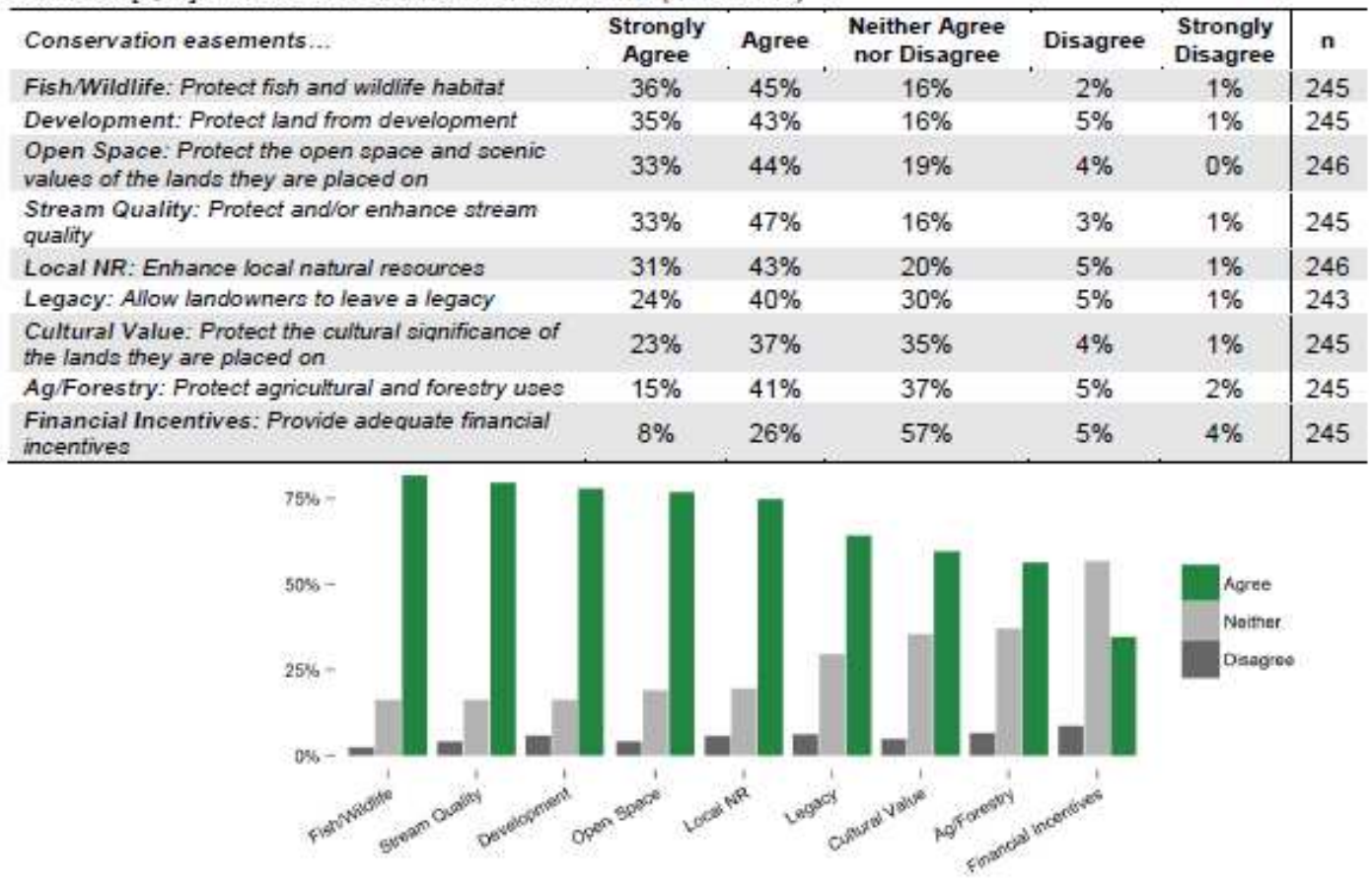

Figure 3.2 [Q10] Beliefs about conservation easements $(n=243-245)$

\section{Attitudes towards Conservation Easements}

Q11. In general, how much do you agree or disagree with the following statements about placing a conservation easement on your property?

In general, respondents did not have strong attitudes towards CEs (Figure 3.3), except in terms of three items: 1) good for fish and wildlife habitat, 2) convenient for my heirs and 3 ) useful to protect my land from development (Table 3.4). 
Table 3.4 [Q11] Attitudes towards conservation easements ( $n=242-245)$

\begin{tabular}{|c|c|c|c|c|c|c|}
\hline $\begin{array}{l}\text { Placing a conservation easement on my } \\
\text { property would be... }\end{array}$ & $\begin{array}{c}\text { Strongly } \\
\text { Agree }\end{array}$ & Agree & $\begin{array}{l}\text { Neither Agree } \\
\text { nor Disagree }\end{array}$ & Disagree & $\begin{array}{l}\text { Strongly } \\
\text { Disagree }\end{array}$ & $\mathbf{n}$ \\
\hline $\begin{array}{l}\text { Fish/Wildlife: Good for fish and wildife } \\
\text { habitat }\end{array}$ & $18 \%$ & $33 \%$ & $28 \%$ & $14 \%$ & $7 \%$ & 244 \\
\hline $\begin{array}{l}\text { Development: Useful to protect my land from } \\
\text { development }\end{array}$ & $11 \%$ & $33 \%$ & $32 \%$ & $16 \%$ & $8 \%$ & 243 \\
\hline Heirs: Convenient for my heirs & $8 \%$ & $12 \%$ & $39 \%$ & $33 \%$ & $8 \%$ & 242 \\
\hline $\begin{array}{l}\text { "Compatible: Compatible with how } 1 \\
\text { currently manage my land }\end{array}$ & $8 \%$ & $25 \%$ & $42 \%$ & $18 \%$ & $7 \%$ & 244 \\
\hline $\begin{array}{l}\text { Inexpensive: inexpensive for me and } m y \\
\text { family }\end{array}$ & $7 \%$ & $15 \%$ & $63 \%$ & $14 \%$ & $1 \%$ & 245 \\
\hline Community: Important for my community & $6 \%$ & $26 \%$ & $51 \%$ & $11 \%$ & $6 \%$ & 245 \\
\hline Financial Benefit: Wise for me financially & $2 \%$ & $8 \%$ & $66 \%$ & $15 \%$ & $9 \%$ & 244 \\
\hline Easy: Easy for me and my family to do & $1 \%$ & $15 \%$ & $64 \%$ & $15 \%$ & $5 \%$ & 242 \\
\hline
\end{tabular}

"Note that the original question items were on opposite scales and were inverted for ease of comparison.

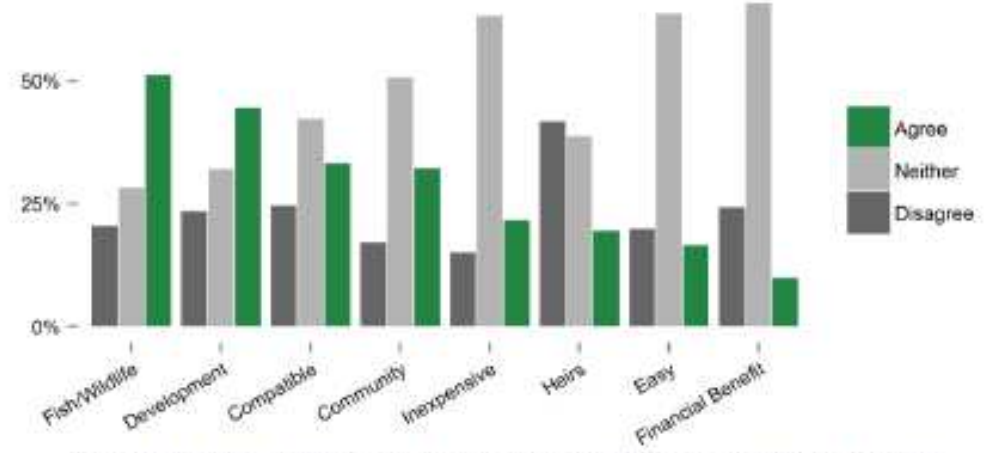

Figure 3.3 [Q11] Attitudes towards conservation easements ( $n=242-245)$

\section{Risk and Conservation Easements}

Q12. Please indicate the level of risk that you think landowners face when placing a conservation easement on their property. Select one response for each.

The three items with the highest levels of perceived risk included 1) future regulatory burdens, 2) causing difficulty in the future sale of the property and 3) resulting in the loss of privacy (Figure 3.4). The item with the lowest amount of perceived risk was "decreasing the county property tax revenue" (Table 3.5). Respondents also perceived a low risk of 1) taking land out of production, 2) creating issues with neighbors and 3 ) reducing the amount of land in private ownership. 
Table 3.5 [Q12] Perceived risk to landowners when placing conservation easement on property ( $n=239-243)$

\begin{tabular}{|c|c|c|c|c|c|c|}
\hline Risk of. & Very High & High & Unsure & Low & Very Low & $\mathrm{n}$ \\
\hline $\begin{array}{l}\text { Future Sale: Causing difficulty in the future sale of the } \\
\text { property }\end{array}$ & $17 \%$ & $30 \%$ & $38 \%$ & $14 \%$ & $1 \%$ & 242 \\
\hline Regulatory Burden: Future regulatory burdens & $14 \%$ & $23 \%$ & $43 \%$ & $16 \%$ & $4 \%$ & 243 \\
\hline Privacy: Resulting in the loss of privacy & $12 \%$ & $15 \%$ & $39 \%$ & $29 \%$ & $5 \%$ & 243 \\
\hline Out of Production: Taking land out of production & $9 \%$ & $13 \%$ & $44 \%$ & $23 \%$ & $11 \%$ & 239 \\
\hline $\begin{array}{l}\text { Issue with Neighbors: Creating issues with neighboring } \\
\text { landowners }\end{array}$ & $8 \%$ & $15 \%$ & $41 \%$ & $30 \%$ & $6 \%$ & 243 \\
\hline $\begin{array}{l}\text { Private Ownership: Reducinq the amount of land in orivate } \\
\text { ownership }\end{array}$ & $8 \%$ & $11 \%$ & $43 \%$ & $23 \%$ & $15 \%$ & 242 \\
\hline $\begin{array}{l}\text { County Tax Revenue: Decreasing county property tax } \\
\text { revenue }\end{array}$ & $6 \%$ & $4 \%$ & $59 \%$ & $24 \%$ & $7 \%$ & 241 \\
\hline
\end{tabular}

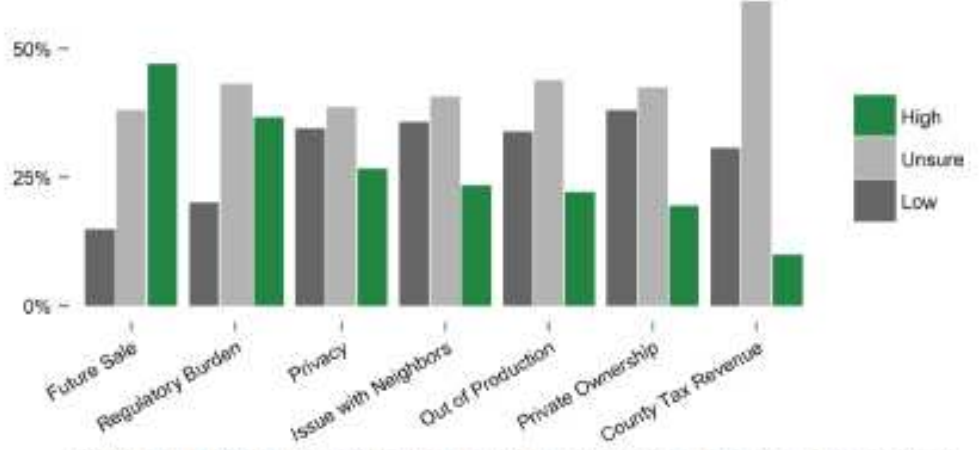

Figure 3.4 [Q12] Perceived risk to landowners when placing conservation easement on property ( $n=239-243)$

\section{Interest in Conservation Easements}

Q13. In general, how fikely or unlikely would you be to place a conservation easement on your property? Select one response. $(n=245)$

This was an important question to evaluate respondents' interest in CEs. Section Six provides a closer look at the differences amongst those who answered 1) Very Likely or Likely, 2) Neither Likely nor Unlikely and 3) Very Unlikely or Unlikely.

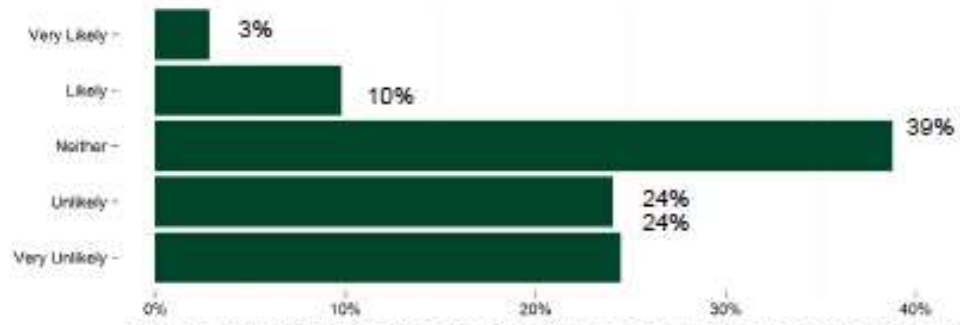

Figure 3.5 [Q13] Likelihood of placing a conservation easement on their property $(n=245)$ 
Q14. Assuming you were considering a conservation easement, how likely or unlikely is it that you would place a conservation easement on your property under the following conditions? Select one response for each.

Respondents were unlikely to place a CE on their property if there was a cost associated it (Table 3.7). Respondents' likelihood increased if they were 1) paid the value of the $C E, 2$ ) offered a property tax benefit, 3) an estate tax benefit, 4) an income tax benefit or 5) given property rights assurances to guarantee that no additional regulatory burdens would arise as a result of the $\mathrm{CE}$ (Figure 3.6 ).

Table 3.7 [Q14] Likelihood of placing a conservation easement on your property ( $n=235-237)$

\begin{tabular}{|c|c|c|c|c|c|c|}
\hline & $\begin{array}{l}\text { Very } \\
\text { Likely }\end{array}$ & Likely & $\begin{array}{l}\text { Neither Likely } \\
\text { nor Unlikely }\end{array}$ & Unlikely & $\begin{array}{l}\text { Very } \\
\text { Unlikely }\end{array}$ & $\mathbf{n}$ \\
\hline $\begin{array}{l}\text { Value of CE: If you were paid for the value of the } \\
\text { conservation easement }\end{array}$ & $14 \%$ & $35 \%$ & $32 \%$ & $8 \%$ & $11 \%$ & 235 \\
\hline Income Tax: If you received an income tax benefit & $12 \%$ & $34 \%$ & $34 \%$ & $10 \%$ & $10 \%$ & 237 \\
\hline $\begin{array}{l}\text { Rights Assurances: If you were offered property } \\
\text { rights assurances to guarantee no additional } \\
\text { regulatory burdens would arise as a result of your } \\
\text { conservation easement }\end{array}$ & $12 \%$ & $39 \%$ & $30 \%$ & $8 \%$ & $11 \%$ & 236 \\
\hline Property Tax: If you received a property tax benefit & $11 \%$ & $39 \%$ & $30 \%$ & $10 \%$ & $10 \%$ & 235 \\
\hline $\begin{array}{l}\text { Estate Tax: if you received an estate tax benefit that } \\
\text { minimized burden for your heirs }\end{array}$ & $11 \%$ & $31 \%$ & $34 \%$ & $12 \%$ & $12 \%$ & 235 \\
\hline $\begin{array}{l}\text { No Cost or Benefit: If there were no financial costs } \\
\text { or benefits to you }\end{array}$ & $4 \%$ & $17 \%$ & $36 \%$ & $26 \%$ & $17 \%$ & 236 \\
\hline $\begin{array}{l}\text { Make Donation: If you were asked to make a } \\
\text { donation to support the land trust's management of } \\
\text { the consenation easement }\end{array}$ & $2 \%$ & $14 \%$ & $40 \%$ & $23 \%$ & $21 \%$ & 236 \\
\hline $\begin{array}{l}\text { Cost: If you had to pay for the costs associated with } \\
\text { placing a conservation easement on your property }\end{array}$ & $1 \%$ & $2 \%$ & $18 \%$ & $41 \%$ & $38 \%$ & 236 \\
\hline
\end{tabular}

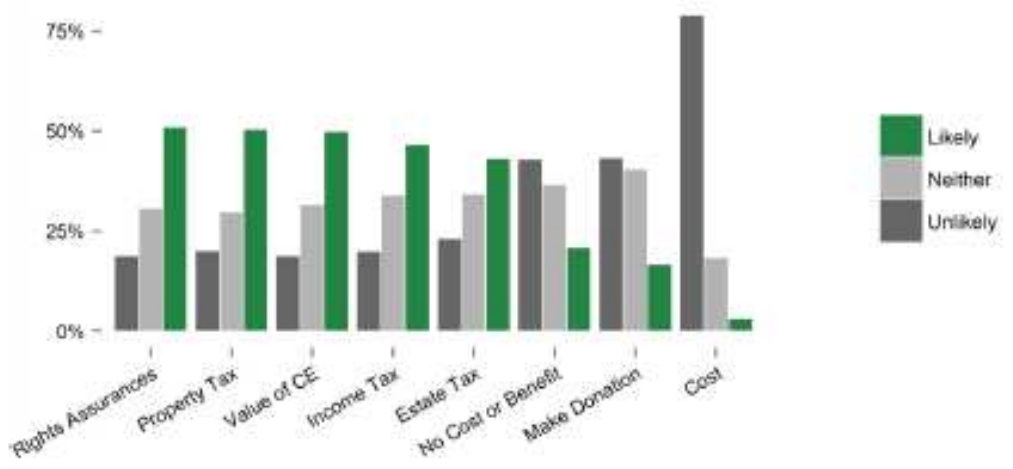

Figure 3.6 [Q14] Likelihood of placing a conservation easement on your property under different situations ( $n=235-237)$ 


\section{SECTION FOUR}

\section{Land Management and You}

This section summarizes the responses to questions in the Land Management and You section of the survey. The questions asked landowners about their experience with select land management practices and their likelihood of implementing these practices in the next five years. Landowners were also asked how supportive they thought their community was of these practices. Additionally, this section included a question that asked respondents about important factors in their land management decisions.

\section{Land Management Practices}

Q15. Please check the box on the left if you or someone you know is currently doing any of the following land management practices. Then, for all of the management practices, please indicate your level of experience with that practice on the right.

Over $50 \%$ of respondents reported that they are currently controlling invasive species and thinning forest on their property to reduce wildfire risk (Table 4.1). Very few respondents have developed a management plan for their property or have participated in a federal land reserve program, which is also reflected in their level of experience with these practices.

Table 4.1 [Q15] Respondents' experience with management practices ( $n=190-211)$

\begin{tabular}{|c|c|c|c|c|c|c|c|}
\hline & $\begin{array}{c}\text { Currently } \\
\text { Doing This }\end{array}$ & $\begin{array}{c}\text { Know Someone } \\
\text { Doing This }\end{array}$ & n & $\begin{array}{c}\text { No } \\
\text { Experience }\end{array}$ & $\begin{array}{c}\text { Some } \\
\text { Experience }\end{array}$ & $\begin{array}{c}\text { A lot of } \\
\text { Experience }\end{array}$ & $\mathbf{n}$ \\
\hline Controlling invasive species & $61 \%$ & $23 \%$ & 246 & $18 \%$ & $67 \%$ & $14 \%$ & 190 \\
\hline $\begin{array}{l}\text { Thinning forest to reduce } \\
\text { wildfire risk }\end{array}$ & $54 \%$ & $27 \%$ & 246 & $23 \%$ & $54 \%$ & $23 \%$ & 191 \\
\hline Planting native vegetation & $46 \%$ & $24 \%$ & 244 & $34 \%$ & $55 \%$ & $11 \%$ & 188 \\
\hline Improving irrigation efficiency & $29 \%$ & $18 \%$ & 244 & $55 \%$ & $35 \%$ & $10 \%$ & 179 \\
\hline Installing vegetative buffers & $17 \%$ & $12 \%$ & 244 & $68 \%$ & $26 \%$ & $6 \%$ & 198 \\
\hline $\begin{array}{l}\text { Developing a written } \\
\text { management plan }\end{array}$ & $9 \%$ & $10 \%$ & 245 & $77 \%$ & $17 \%$ & $6 \%$ & 211 \\
\hline Restoring aquatic habitat & $9 \%$ & $20 \%$ & 244 & $69 \%$ & $27 \%$ & $4 \%$ & 199 \\
\hline $\begin{array}{l}\text { Participating in federal land } \\
\text { reserve programs (i.e. CRP) }\end{array}$ & $2 \%$ & $7 \%$ & 244 & $90 \%$ & $10 \%$ & $0 \%$ & 209 \\
\hline
\end{tabular}

Q16. In the next five years, how likely or unlikely is it that you would implement the following management practices on your land?

Greater than $50 \%$ of respondents marked that they are likely to control for invasive species, thin forest to reduce wildfire risk and plant native vegetation on their property (Figure 4.1 ). Conversely, about $50 \%$ of respondents specified that they are unlikely to restore aquatic habitat, participate in a federal land reserve program and develop a written management plan. 
Table 4.2 [Q16] Likelihood of implementing select management practices ( $n=234-246)$

\begin{tabular}{|c|c|c|c|c|c|c|}
\hline & $\begin{array}{l}\text { Very } \\
\text { Likely }\end{array}$ & Likely & $\begin{array}{c}\text { Neither Likely } \\
\text { nor Unlikely }\end{array}$ & Unlikely & $\begin{array}{c}\text { Very } \\
\text { Unlikely }\end{array}$ & $\mathbf{n}$ \\
\hline Controlling invasive species & $47 \%$ & $33 \%$ & $12 \%$ & $5 \%$ & $3 \%$ & 246 \\
\hline Thinning forest to reduce wildfire risk & $41 \%$ & $24 \%$ & $17 \%$ & $12 \%$ & $6 \%$ & 246 \\
\hline Planting native vegetation & $30 \%$ & $35 \%$ & $21 \%$ & $8 \%$ & $6 \%$ & 243 \\
\hline Improving irrigation efficiency & $23 \%$ & $23 \%$ & $30 \%$ & $13 \%$ & $11 \%$ & 234 \\
\hline Installing vegetative buffers & $10 \%$ & $18 \%$ & $38 \%$ & $18 \%$ & $16 \%$ & 238 \\
\hline Developing a written management plan & $6 \%$ & $6 \%$ & $32 \%$ & $27 \%$ & $29 \%$ & 242 \\
\hline Restoring aquatic habitat & $6 \%$ & $10 \%$ & $30 \%$ & $26 \%$ & $27 \%$ & 234 \\
\hline Participating in federal land reserve programs & $2 \%$ & $5 \%$ & $38 \%$ & $26 \%$ & $29 \%$ & 238 \\
\hline
\end{tabular}

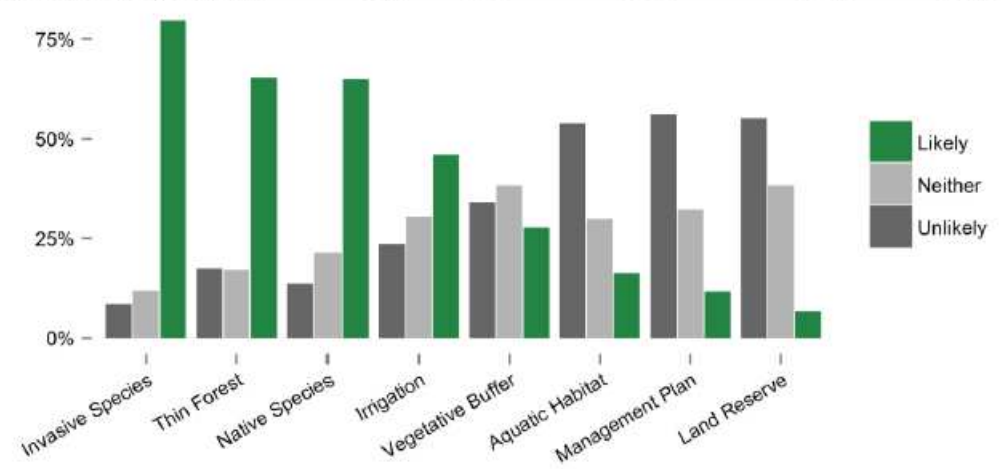

Figure 4.1 [Q16] Likelihood of implementing select management practices $(n=234-246)$

Q17. How often do you take part in the following types of behaviors?

Most respondents marked that they Never partake in the listed behaviors, however, about $20 \%$ of respondents Annually steward/care for a protected natural area or help a neighbor with the management of their land (Table 4.3). About $10 \%$ of respondents steward/care for protected natural areas or help their neighbor with land management Every Few Months.

Table 4.3 [Q16] Frequency of performing specific conservation actions ( $n=244-246)$

\begin{tabular}{lccccccc|c}
\hline & Never & Annually & $\begin{array}{c}\text { Every } \\
\text { Few } \\
\text { Months }\end{array}$ & Monthly & $\begin{array}{c}\text { Every } \\
\text { Few } \\
\text { Weeks }\end{array}$ & Weekly & $\begin{array}{c}\text { More than } \\
\text { Once a } \\
\text { Week }\end{array}$ & n \\
\hline $\begin{array}{l}\text { Work with an organization to } \\
\text { restore your land }\end{array}$ & $88 \%$ & $8 \%$ & $2 \%$ & $0 \%$ & $0 \%$ & $0 \%$ & $1 \%$ & 246 \\
$\begin{array}{l}\text { Volunteer with a land trust } \\
\begin{array}{l}\text { Help a neighbor with the } \\
\text { management of their land }\end{array}\end{array}$ & $82 \%$ & $13 \%$ & $3 \%$ & $0 \%$ & $1 \%$ & $0 \%$ & $1 \%$ & 245 \\
$\begin{array}{l}\text { Steward or care for protected } \\
\text { natural areas }\end{array}$ & $69 \%$ & $18 \%$ & $10 \%$ & $1 \%$ & $1 \%$ & $1 \%$ & $0 \%$ & 244 \\
\hline
\end{tabular}




\section{Important Factors in Land Management Decisions}

Q18. When making decisions about your land, how important are the following factors to you?

Over $75 \%$ of respondents considered protecting the open space and scenic qualities of their property and providing a primary residence as Important or Very Important (Figure 4.2). Over $50 \%$ of respondents considered enhancing their community's natural resources, leaving a legacy for future generations, providing recreational opportunities, protecting fish and wildlife habitat and stream quality as important or Very important when making decisions about their land. The least important factors to respondents included 1) providing an income and 2) protecting the cultural significance of their property (Table 4.5).

Table 4.4 [Q18] important factors in land management decisions $(n=235-248)$

\begin{tabular}{|c|c|c|c|c|c|c|}
\hline & $\begin{array}{c}\text { Very } \\
\text { Important }\end{array}$ & Important & $\begin{array}{l}\text { Moderately } \\
\text { Important }\end{array}$ & $\begin{array}{c}\text { Slightly } \\
\text { Important }\end{array}$ & $\begin{array}{l}\text { Not at all } \\
\text { Important }\end{array}$ & $n$ \\
\hline $\begin{array}{l}\text { Open Space: Protecting the open space and } \\
\text { acenic qualities of my property }\end{array}$ & $76 \%$ & $16 \%$ & $6 \%$ & $1 \%$ & $1 \%$ & 248 \\
\hline Residence: Providing a primary residence & $64 \%$ & $20 \%$ & $7 \%$ & $4 \%$ & $5 \%$ & 245 \\
\hline $\begin{array}{l}\text { Development: Protecting my property from } \\
\text { development }\end{array}$ & $48 \%$ & $20 \%$ & $17 \%$ & $6 \%$ & $9 \%$ & 246 \\
\hline $\begin{array}{l}\text { Fish/Wildlife: Protection fish and wildlife } \\
\text { habitat }\end{array}$ & $37 \%$ & $37 \%$ & $15 \%$ & $9 \%$ & $2 \%$ & 246 \\
\hline $\begin{array}{l}\text { Stream Quality: Protecting and/or enhancing } \\
\text { stream quality }\end{array}$ & $35 \%$ & $32 \%$ & $20 \%$ & $4 \%$ & $9 \%$ & 235 \\
\hline $\begin{array}{l}\text { Local NR: Enhancing my community's natural } \\
\text { resources }\end{array}$ & $33 \%$ & $35 \%$ & $20 \%$ & $9 \%$ & $3 \%$ & 248 \\
\hline $\begin{array}{l}\text { Recreation: Providing recreational } \\
\text { opportunities for me and my family }\end{array}$ & $32 \%$ & $32 \%$ & $22 \%$ & $8 \%$ & $6 \%$ & 246 \\
\hline $\begin{array}{l}\text { Legacy: Leaving a legacy for future } \\
\text { generations }\end{array}$ & $30 \%$ & $34 \%$ & $23 \%$ & $7 \%$ & $6 \%$ & 246 \\
\hline $\begin{array}{l}\text { Cultural Values: Protecting the cultural } \\
\text { significance of my property }\end{array}$ & $14 \%$ & $21 \%$ & $29 \%$ & $17 \%$ & $19 \%$ & 241 \\
\hline $\begin{array}{l}\text { Income: Providing an income for me and my } \\
\text { family }\end{array}$ & $11 \%$ & $21 \%$ & $23 \%$ & $18 \%$ & $27 \%$ & 245 \\
\hline
\end{tabular}

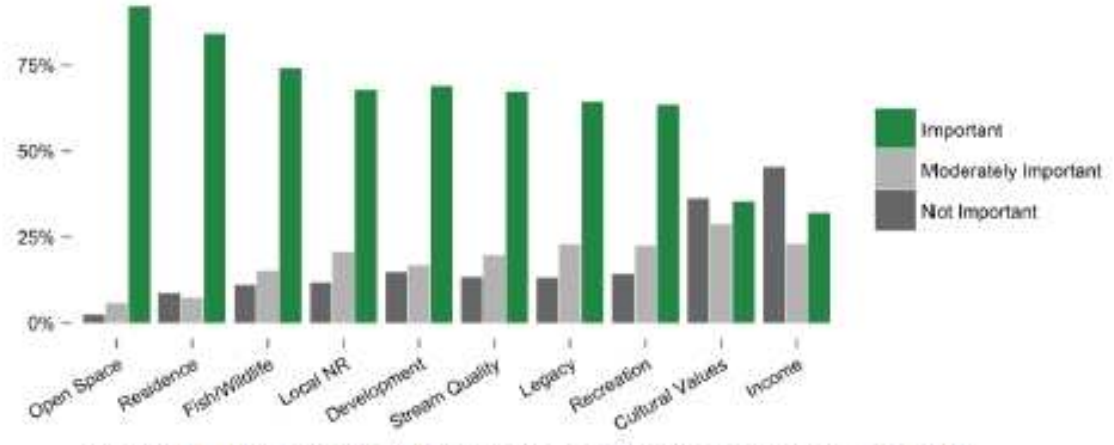

Figure 4.2 [Q18] Important factors in management decisions ( $n=235-248)$ 


\section{Community Support for Land Management Practices}

Q19. How supportive or unsupportive are the people in your community of the following land management practices?

Over $75 \%$ of respondents think people in their community are Supportive or Very Supportive of controlling invasive species, thinning forest to reduce wildfire risk, improving irrigation efficiency and restoring aquatic habitat (Table 4.5, Figure 4.3). Over $50 \%$ of respondents think their community is Neither Supportive nor Unsupportive of CEs, developing a written management plan and participating in federal land reserve programs.

Table 4.5 [Q19] Level of community support for select management practices ( $n=209-225$ )

\begin{tabular}{lcccccc}
\hline & $\begin{array}{c}\text { Very } \\
\text { Supportive }\end{array}$ & Supportive & Neither & Unsupportive & $\begin{array}{c}\text { Very } \\
\text { Unsupportive }\end{array}$ & n \\
\hline Thinning forest to reduce wildfire risk & $32 \%$ & $54 \%$ & $11 \%$ & $2 \%$ & $0 \%$ & 226 \\
Controlling invasive species & $28 \%$ & $54 \%$ & $15 \%$ & $3 \%$ & $0 \%$ & 225 \\
Restoring aquatic habitat & $23 \%$ & $45 \%$ & $29 \%$ & $3 \%$ & $0 \%$ & 221 \\
Improving irrigation efficiency & $15 \%$ & $49 \%$ & $30 \%$ & $5 \%$ & $1 \%$ & 219 \\
$\begin{array}{l}\text { Installing vegetative buffers } \\
\text { Developing a written management plan }\end{array}$ & $9 \%$ & $39 \%$ & $45 \%$ & $6 \%$ & $1 \%$ & 213 \\
$\begin{array}{l}\text { Placing conservation easement on } \\
\text { property }\end{array}$ & $5 \%$ & $23 \%$ & $61 \%$ & $7 \%$ & $1 \%$ & 215 \\
$\begin{array}{l}\text { Participating in federal land reserve } \\
\text { programs (i.e. CRP) }\end{array}$ & $4 \%$ & $19 \%$ & $67 \%$ & $7 \%$ & 215 \\
\hline
\end{tabular}

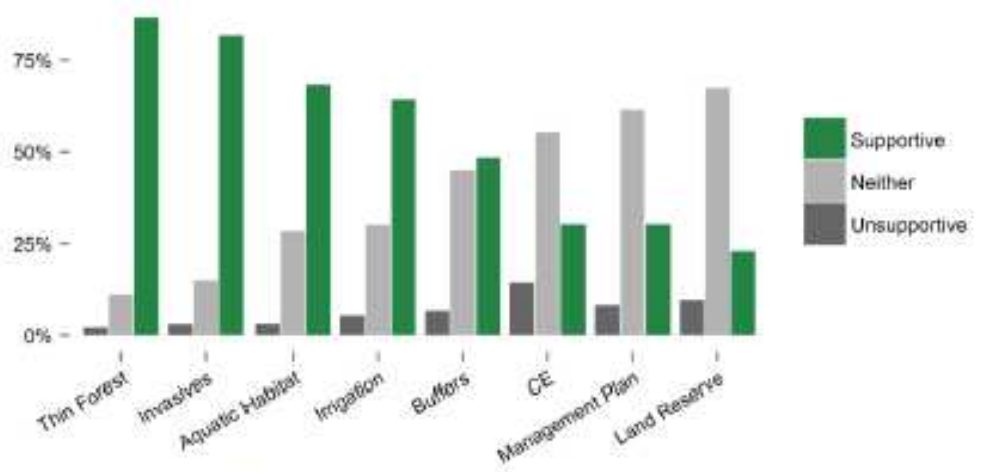

Figure 4.3 [Q19] Level of community support for select management practices $(n=209-225)$ 


\section{Your Community and You}

This section summarizes the responses to questions in the Your Community and You section of the survey. These questions asked about landowners' connection with the physical environment and social community within the Whychus Creek Watershed. Additionally, this section included questions about respondents' interactions with their neighbors and other important sources of land management information.

\section{Place Connections}

Q20. How attached do you feel to each of the following places?

More than $50 \%$ of respondents reported being Extremely Attached or Very Attached to the City of Sisters, Whychus Creek Watershed, Central Oregon, Pacific Northwest and the Western U.S. Most respondents reported being Slightly Attached or Not Attached to the City of Bend.

Table 5.1 [Q20] Level of attachment to different places ( $n=239-243$ )

\begin{tabular}{lcccccc}
\hline & $\begin{array}{c}\text { Extremely } \\
\text { Attached }\end{array}$ & $\begin{array}{c}\text { Very } \\
\text { Attached }\end{array}$ & $\begin{array}{c}\text { Moderately } \\
\text { Attached }\end{array}$ & $\begin{array}{c}\text { Slightly } \\
\text { Attached }\end{array}$ & $\begin{array}{c}\text { Not } \\
\text { Attached }\end{array}$ & $\begin{array}{c}\text { n } \\
\text { Attic Northwest }\end{array}$ \\
\hline Pacific & $36 \%$ & $37 \%$ & $16 \%$ & $7 \%$ & $4 \%$ & 241 \\
Westem U.S. & $27 \%$ & $35 \%$ & $25 \%$ & $8 \%$ & $5 \%$ & 239 \\
City of Sisters & $23 \%$ & $35 \%$ & $27 \%$ & $8 \%$ & $7 \%$ & 242 \\
Whychus Creek Watershed & $22 \%$ & $34 \%$ & $28 \%$ & $10 \%$ & $6 \%$ & 243 \\
Central Oregon & $18 \%$ & $44 \%$ & $27 \%$ & $7 \%$ & $4 \%$ & 241 \\
Upper Deschutes Watershed & $12 \%$ & $30 \%$ & $30 \%$ & $16 \%$ & $12 \%$ & 243 \\
City of Bend & $1 \%$ & $11 \%$ & $37 \%$ & $26 \%$ & $25 \%$ & 241 \\
\hline
\end{tabular}

Q21. How much do you agree or disagree with the following statements about the importance of the Whychus Creek Watershed to you personally?

Table 5.2 shows the percentage of respondents who agreed or disagreed with each statement about the Whychus Creek Watershed. The items in this question were based on the Sense of Place Scale ${ }^{1}$ (Jorgensen and Stedman 2001). In general, more respondents agreed than disagreed with each of the statements. The following statements showed the highest levels of disagreement: 1) don't identify with the Whychus Creek Watershed, 2) there are better places to be and 3) enjoy the activities I undertake here just as well in another place (Figure 5.1).

'The Sense of Place Scale measures place attachment, place identity and place dependence. "Be Myself." Type of Person" and "Don't identify" measure identity. "Miss It", "Favorite Place" and "Happiest" measure attachment and "Best Place,"

"Enjoy Other Places" and "Better Places" measure place dependence. 
Table 5.2 [Q21] Place connection to Whychus Creek Watershed $(n=233-240)$

\begin{tabular}{|c|c|c|c|c|c|c|}
\hline & $\begin{array}{l}\text { Strongly } \\
\text { Agree }\end{array}$ & Agree & $\begin{array}{c}\text { Neither Agree } \\
\text { nor Disagree }\end{array}$ & Disagree & $\begin{array}{l}\text { Strongly } \\
\text { Disagree }\end{array}$ & $\mathbf{n}$ \\
\hline $\begin{array}{l}\text { Be Myself: I feel I can really be mycelf when I am } \\
\text { there }\end{array}$ & $16 \%$ & $35 \%$ & $43 \%$ & $5 \%$ & $1 \%$ & 237 \\
\hline Miss it: I really miss it when I am away foo long & $16 \%$ & $41 \%$ & $32 \%$ & $9 \%$ & $2 \%$ & 234 \\
\hline Type of Person: It refiects the type of person l am & $13 \%$ & $43 \%$ & $40 \%$ & $4 \%$ & $0 \%$ & 234 \\
\hline Favorite Place: It is my favorite place to be & $12 \%$ & $37 \%$ & $43 \%$ & $7 \%$ & $1 \%$ & 240 \\
\hline Happiest: I feel happiest when I am there & $11 \%$ & $32 \%$ & $48 \%$ & $7 \%$ & $2 \%$ & 233 \\
\hline $\begin{array}{l}\text { Best Place: It is the best place for doing the things } \\
\text { I enjoy }\end{array}$ & $10 \%$ & $34 \%$ & $48 \%$ & $7 \%$ & $1 \%$ & 238 \\
\hline $\begin{array}{l}\text { Don't Identify: I really don't identify with the } \\
\text { Whychus Creek Watershed }\end{array}$ & $4 \%$ & $15 \%$ & $30 \%$ & $36 \%$ & $15 \%$ & 238 \\
\hline $\begin{array}{l}\text { Enjoy Other Places: I would enjoy the activities I } \\
\text { undertake here just as well in another place }\end{array}$ & $3 \%$ & $32 \%$ & $40 \%$ & $23 \%$ & $2 \%$ & 235 \\
\hline $\begin{array}{l}\text { Better Places: As far as } I \text { am concemed, there are } \\
\text { better places to be }\end{array}$ & $2 \%$ & $17 \%$ & $48 \%$ & $26 \%$ & $7 \%$ & 239 \\
\hline
\end{tabular}

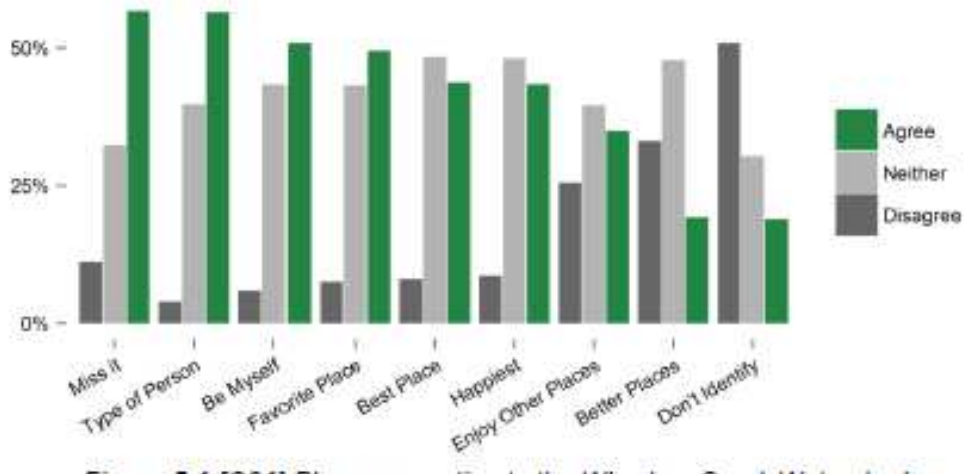

Figure 5.1 [Q21] Place connection to the Whychus Creek Watershed $(n=233-240)$

\section{Community Connections}

Q22. How much do you agree or disagree with the following statements about the importance, to you personally, of your community within the Whychus Creek Watershed?

The items in this question were based on the Brief Sense of Community Scale ${ }^{1}$ (Peterson et al, 2008). In general, more respondents agreed than disagreed with each of the statements (Table 5.3, Figure 5.2). Items with the least amount of agreement included 1) have a say about what goes on in my community, 2) people in my community are good at influencing each other and 3) my community helps me fulfill my needs.

1 "Needs" and "Fulfill Needs" measure needs fulfillment; "Connected" and "Good Bond" measure emotional connection; "Member" and "Belong" measure membership and "Have a Say" and "Influence" measure influence. 
Table 5.3 [Q22] Community of Whychus Creek Watershed as allowing for needs fulfillment, emotional connection, membership and influence $(n=233-238)$

\begin{tabular}{|c|c|c|c|c|c|c|}
\hline & $\begin{array}{l}\text { Strongly } \\
\text { Agree }\end{array}$ & Agree & $\begin{array}{c}\text { Neither Agree } \\
\text { nor Disagree }\end{array}$ & Disagree & $\begin{array}{l}\text { Strongly } \\
\text { Disagree }\end{array}$ & n \\
\hline Member: I feel like a member of my community & $10 \%$ & $52 \%$ & $30 \%$ & $6 \%$ & $2 \%$ & 237 \\
\hline $\begin{array}{l}\text { Good Bond: I have a good bond with others in } \\
\text { my community }\end{array}$ & $9 \%$ & $53 \%$ & $29 \%$ & $7 \%$ & $2 \%$ & 235 \\
\hline Connected: I feel connected to my community & $8 \%$ & $55 \%$ & $29 \%$ & $6 \%$ & $2 \%$ & 238 \\
\hline Belong: I belong in my community & $8 \%$ & $52 \%$ & $33 \%$ & $4 \%$ & $3 \%$ & 236 \\
\hline Needs: $f$ can get what I need in my community & $6 \%$ & $61 \%$ & $26 \%$ & $6 \%$ & $1 \%$ & 237 \\
\hline $\begin{array}{l}\text { Have a Say: I have a say about what goes on in } \\
\text { my community }\end{array}$ & $3 \%$ & $30 \%$ & $44 \%$ & $17 \%$ & $6 \%$ & 237 \\
\hline $\begin{array}{l}\text { Influence: People in my community are good at } \\
\text { influencing each other }\end{array}$ & $3 \%$ & $30 \%$ & $50 \%$ & $14 \%$ & $3 \%$ & 236 \\
\hline $\begin{array}{l}\text { Fulfill Needs: My community helps me fulfill my } \\
\text { needs }\end{array}$ & $2 \%$ & $34 \%$ & $51 \%$ & $10 \%$ & $3 \%$ & 233 \\
\hline
\end{tabular}

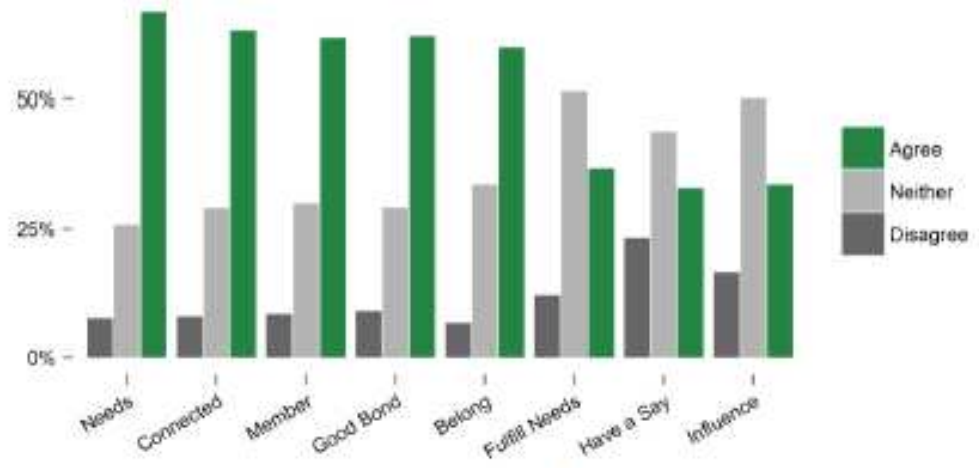

Figure 5.2 [Q22] Community connection to the Whychus Creek Watershed $(n=233-238)$

\section{Social Interactions in the Whychus Creek Watershed}

Q23. How often do you talk to your neighbors about the following items?

Table 5.4 shows the percentage of respondents who talk to their neighbors about various subjects including the use and management of their land, future plans for their land, protection of Whychus Creek Watershed, land management programs and conservation in general. About $50 \%$ responded that they Never talk to their neighbors about these subjects. However, about $20 \%$ responded that they talk to their neighbors about the use and management of their land, future plans for their land and conservation in general Every Few Months. 
Table 5.4 [Q23] Frequency that respondents talk to their neighbors about various conservation and land management subjects ( $n=244-246)$

\begin{tabular}{|c|c|c|c|c|c|c|c|c|}
\hline & Never & Annually & $\begin{array}{c}\text { Every } \\
\text { Few } \\
\text { Months }\end{array}$ & Monthly & $\begin{array}{c}\text { Every } \\
\text { Few } \\
\text { Weeks }\end{array}$ & Weekly & $\begin{array}{c}\text { More than } \\
\text { Once a } \\
\text { Week }\end{array}$ & n \\
\hline Land management programs & $56 \%$ & $23 \%$ & $14 \%$ & $3 \%$ & $1 \%$ & $2 \%$ & $0 \%$ & 245 \\
\hline $\begin{array}{l}\text { Protection of the Whychus Creek } \\
\text { Watershed }\end{array}$ & $50 \%$ & $25 \%$ & $15 \%$ & $5 \%$ & $3 \%$ & $1 \%$ & $1 \%$ & 245 \\
\hline Future plans for your land & $49 \%$ & $28 \%$ & $18 \%$ & $1 \%$ & $2 \%$ & $2 \%$ & $0 \%$ & 246 \\
\hline Use or management of your land & $43 \%$ & $28 \%$ & $22 \%$ & $3 \%$ & $3 \%$ & $1 \%$ & $0 \%$ & 246 \\
\hline Conservation in general & $36 \%$ & $30 \%$ & $22 \%$ & $4 \%$ & $4 \%$ & $2 \%$ & $2 \%$ & 244 \\
\hline
\end{tabular}

Q24. What does neighbor mean to you? $(n=243)$

- $44 \%$ said "People that live in the same general community as me"

- $21 \%$ said "People that live next to me, but also people a few houses down"

- $20 \%$ said People who live within a mile of $\mathrm{me}^{*}$

- $6 \%$ said "People who live within two miles of me"

- $5 \%$ said "Only the people that live on the land next to me"

- $5 \%$ said "Other"

Q25. How often do you take note of how your neighbor manages their land?

Greater than $80 \%$ of respondents reported that they observe how their neighbor manages their land at least Sometimes, while $3 \%$ reported that they Never take note of how their neighbor manages their land (Table 5.5).

Q26. How often have you specifically done something because of your neighbor's success with it?

Although, respondents observe how their neighbor manages their land, they don't necessarily act on these observations. About $50 \%$ of respondents reported that they Never or Rarely do something specifically because of their neighbor's success with it, while $42 \%$ Sometimes do something because of their neighbor's success with it (Table 5.5).

Q27. How often have you specifically avoided doing something because of your neighbor's failure with it?

Few respondents avoid doing something because of their neighbor's failure with that method (Table 5.5). $32 \%$ reported that they Sometimes avoid doing something because of their neighbor's failure with that method.

Table 5.5 Frequency that respondents observe and respond to neighbor's management of land [Q25,26,27]

\begin{tabular}{lccccc|c}
\hline & Never & Rarely & Sometimes & Often & All the Time & n \\
\hline Q25. Take note of how your neighbor manages their land & $3 \%$ & $14 \%$ & $32 \%$ & $35 \%$ & $16 \%$ & 255 \\
Q26. Done something & $26 \%$ & $23 \%$ & $42 \%$ & $7 \%$ & $2 \%$ & 254 \\
Q27. Avoided something & $35 \%$ & $21 \%$ & $32 \%$ & $9 \%$ & $3 \%$ & 239 \\
\hline
\end{tabular}


Q28. How much do you trust land management information from the following individuals or institutions?

The top three information sources that respondents had High Trust for included 1) spouse, 2) land trusts and 3) watershed councils (Table 5.6). The top three information sources that respondents had Moderate Trust for included 1) neighbors, 2) soil and water conservation districts and 3) extension staff. The top three information sources that respondents had No Trust for included 1) government agencies, 2) environmental organizations and 3) producers groups. Most respondents reported that they were Unsure about producer groups.

Table 5.6 [Q28] Level of trust for land management information from various sources ( $n=218-235)$

\begin{tabular}{|c|c|c|c|c|c|c|}
\hline & High Trust & Moderate Trust & A Little Trust & No Trust & Unsure & $\mathrm{n}$ \\
\hline Spouse & $51 \%$ & $25 \%$ & $8 \%$ & $5 \%$ & $11 \%$ & 221 \\
\hline Relatives & $19 \%$ & $33 \%$ & $23 \%$ & $11 \%$ & $15 \%$ & 226 \\
\hline Neighbors & $7 \%$ & $50 \%$ & $30 \%$ & $5 \%$ & $8 \%$ & 230 \\
\hline Land truste & $27 \%$ & $34 \%$ & $18 \%$ & $9 \%$ & $11 \%$ & 235 \\
\hline Waterched councils & $21 \%$ & $35 \%$ & $19 \%$ & $11 \%$ & $13 \%$ & 231 \\
\hline $\begin{array}{l}\text { Environmental } \\
\text { organizations }\end{array}$ & $18 \%$ & $31 \%$ & $22 \%$ & $21 \%$ & $8 \%$ & 234 \\
\hline Producer groups & $0 \%$ & $13 \%$ & $31 \%$ & $18 \%$ & $37 \%$ & 218 \\
\hline Professional consultant & $7 \%$ & $32 \%$ & $33 \%$ & $12 \%$ & $15 \%$ & 231 \\
\hline Extension staff & $17 \%$ & $38 \%$ & $26 \%$ & $7 \%$ & $12 \%$ & 227 \\
\hline $\begin{array}{l}\text { Soil and water conservation } \\
\text { districts }\end{array}$ & $14 \%$ & $41 \%$ & $26 \%$ & $8 \%$ & $10 \%$ & 230 \\
\hline Government agencies & $4 \%$ & $32 \%$ & $28 \%$ & $26 \%$ & $10 \%$ & 234 \\
\hline
\end{tabular}

Q29. When you are struggling with a difficult question or problem related to managing your land, please list the 3 or 4 people whose opinion you most respect. $(n=131)$

301 individuals or institutions were listed by 131 respondents. $21 \%$ of the individuals listed were neighbors; $17 \%$ were spouses; $17 \%$ were affiliated with a government agency; $10 \%$ were friends; $9 \%$ were affiliated with a land trust; $6 \%$ were relatives; $6 \%$ were professionals; $3 \%$ were extension staff; $3 \%$ were environmental organizations; $2 \%$ were attorneys; $2 \%$ were realtors. The remaining $4 \%$ were soil and water conservation districts, watershed councils, fire districts, irrigation districts and farmer or ranchers.

Q30. Have you ever received land management or conservation information from the following individuals or institutions? Check all that apply. $(n=196)$

The top five sources of land management information included 1) land trusts, 2) government agencies, 3) neighbors, 4) environmental organizations and 5) soil and water conservation districts. 
Q31. Whose opinion do you think you would be most likely to follow when making a land management or conservation decision? $(n=237)$

The top five individuals or institutions whose opinion respondents reported being the most likely to follow included 1) spouse, 2) land trusts, 3) professional consultant, 4) soil and water conservation districts and 5) extension staff.

Table 5.7 shows both the percentage of respondents who have received land management information from each of the sources and the percentage of respondents who would follow the opinion of that source when making a land management or conservation decision. The values in bold represent the top five information sources.

Table 5.7 [Q30,31] Information sources and influential opinions with the top Five bolded $(n=196-237)$

\begin{tabular}{lcc}
\hline & Q30 & Q31 \\
\hline Land trusts & $62 \%$ & $27 \%$ \\
Government agencies & $40 \%$ & $3 \%$ \\
Neighbors & $31 \%$ & $8 \%$ \\
Environmental organizations & $30 \%$ & $7 \%$ \\
Soli and water conservation districts & $29 \%$ & $13 \%$ \\
Extension staff & $28 \%$ & $11 \%$ \\
Watershed councils & $26 \%$ & $9 \%$ \\
Spouse & $21 \%$ & $34 \%$ \\
Professional consultant & $16 \%$ & $19 \%$ \\
Relatives & $11 \%$ & $7 \%$ \\
Producer groups & $4 \%$ & $0 \%$ \\
\hline
\end{tabular}




\section{SECTION SIX \\ Response Comparisons by Group}

The following section takes a closer look at the differences between respondents. I grouped respondents into three categories based on their response to Q13-In general, how likely or unlikely would you be to place a conservation easement on your property? If respondents said they were Very Likely or Likely to place a CE on their property they were put in a group referred to as the Yes Group. If respondents said they were Neither Likely nor Unlikely they were put into another group referred to as the Maybe Group. Lastly, respondents that said they were Unlikely or Very Unlikely were put in the No Group. There were 43 respondents in the Yes Group, 95 in the Maybe Group and 119 in the No Group.

\section{Awareness of Conservation Easements}

Awareness of the specific characteristics of CEs may be an important component differentiating respondents based on their likelihood of placing a $\mathrm{CE}$ on their property. Figure 6.1 [Q9] shows the differences in awareness for each group. Refer to Section Three or Appendix $B$ for the full item descriptions.

\section{Key Findings}

The Yes Group, as we might expect, had the smallest percentage of respondents who were Not Aware, whereas the Maybe and No Groups had a much larger amount of respondents who were Not Aware.

Respondents in the Yes Group showed the lowest awareness that CEs 1) give the right to monitor and enforce property restrictions to an eligible organization such as a land trust, 2) may provide financial incentives and 3) do not require public access. About $75 \%$ of respondents in the Yes Group were Aware or Very Aware that CEs 1) limit the uses of a property, 2) can be applied to the entire property or a portion of it, 3) are voluntary and 4) keep land in private ownership. A little over $50 \%$ of the respondents in the No Group were Aware or Very Aware of these characteristics; however, a lower percentage of the respondents in this group were Aware or Very Aware that a CE can be applied to the entire property or a portion of it.

The Maybe Group showed the lowest amount of awareness overail. The Maybe Group was most aware that CEs 1) limit the uses of a property, 2) are voluntary and 3) keep land in private ownership. This comparison may reveal that awareness is a limiting factor for the Maybe Group. 


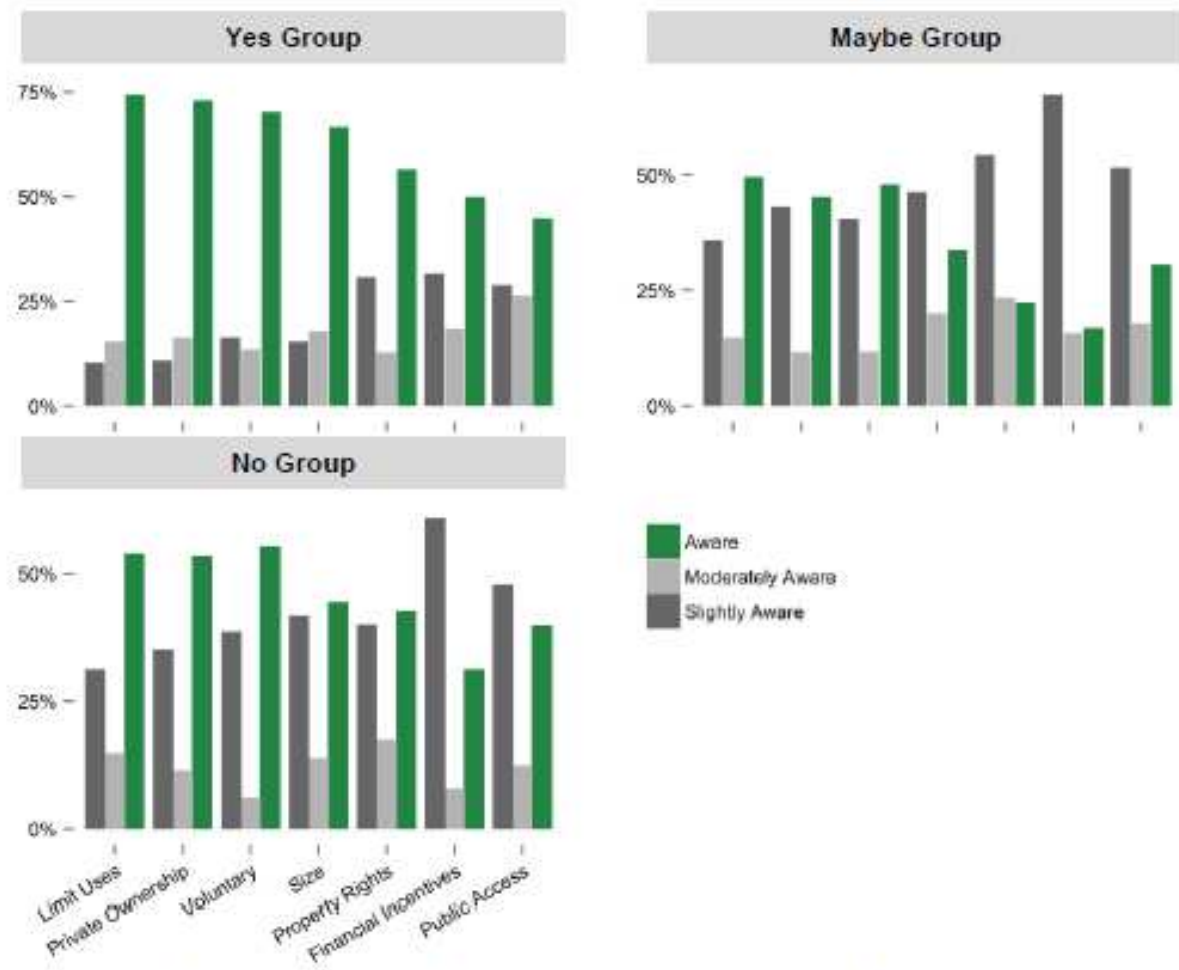

Figure 6.1 [Q9] Awareness: compares respondents in the Yes ( $n=43)$, Maybe $(n=95)$ and No ( $n=119$ ) group based on their responses to $Q 9$

\section{Attitudes towards Conservation Easements}

Additionally, I wanted to explore differences in respondents' attitudes towards CEs based on their group. Figure 6.2 [Q11] on the following pages illustrates these differences. Refer to Section Three or Appendix $B$ for the full item descriptions.

\section{Key Findings}

In general, the Yes Group had more positive attitudes towards CEs than the Maybe and No Groups while the No Group had more negative attitudes. For most items, the Maybe Group expressed a neutral opinion.

The Yes Group agreed that "CEs are important for their community." The Maybe Group agreed with this statement as well, but the No Group did not. The No Group disagreed most with the following statements 1) CEs are convenient for my heirs, 2) CEs are wise for me financially and 3) CEs are compatible with how manage my land. 


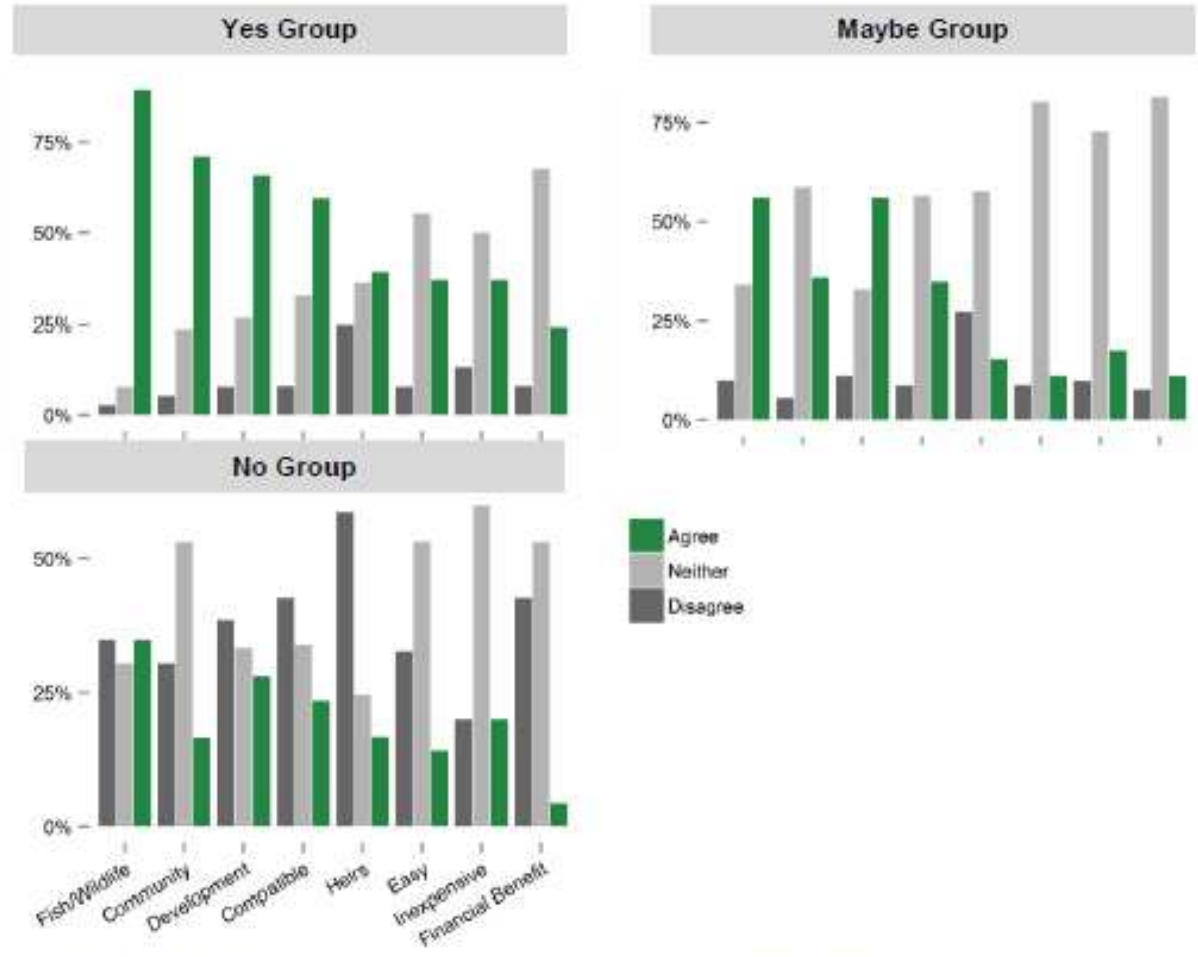

Figure 6.2 [Q11] Attitudes: compares respondents in the Yes ( $n=43)$, Maybe ( $n=95)$ and No ( $n=119$ ) group based on their responses to Q11

\section{Risk and Conservation Easements}

I was interested in determining if respondents in the Yes, Maybe and No Groups perceived different levels of risk associated with CEs. Figure 6.3 [Q12] on the following pages illustrates these differences. Refer to Section Three or Appendix $B$ for the full item descriptions.

\section{Key Findings}

In general, the No Group perceived the highest amount of risk, the Maybe Group was unsure about the amount of risk and the Yes Group perceived the lowest amount of risk associated with CEs.

More than $50 \%$ of respondents in the No Group thought there was a high risk of CEs causing difficulty in the future sale of the property and leading to future regulatory burdens. Another area of high perceived risk for the No Group was the risk of privacy loss. Conversely, more than $50 \%$ of the Yes Group thought this item had low risk. 


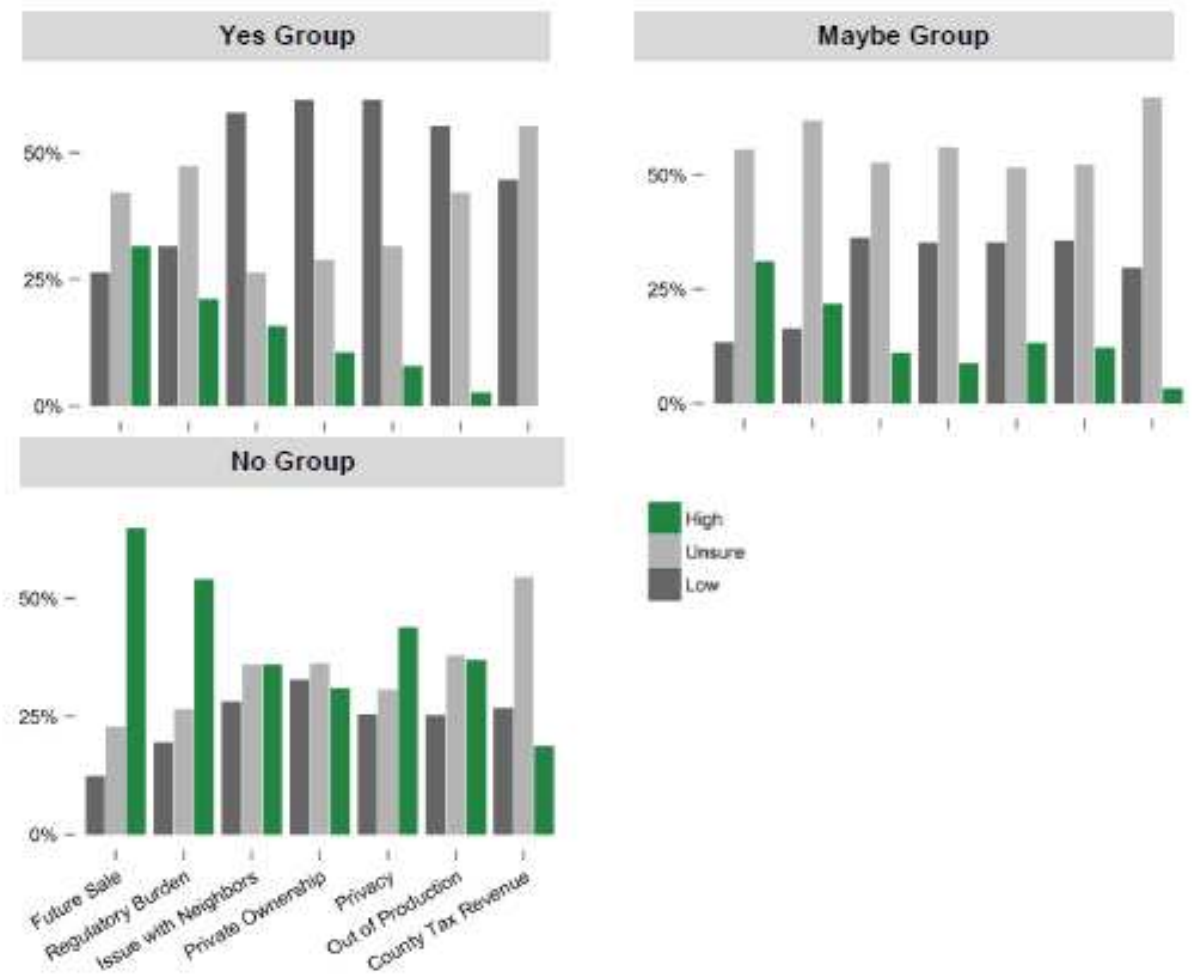

Figure 6.3 [Q12] Risk: compares respondents in the Yes ( $n=43)$, Maybe ( $n=95)$ and No ( $n=119$ ) group based on their responses to Q12

\section{Interest in Conservation Easements}

In order to understand how different costs and benefits may change respondents' likelihood to place a CE on their property I compared the three groups based on their answers to Q14. Figure 6.4 [Q14] on the following pages illustrates these differences. Refer to Section Three or Appendix $B$ for the full item descriptions.

\section{Key Findings}

In the questionnaire respondents were asked, assuming that they were considering a $C E$, how likely or unlikely would they be to place a CE on their property under a various conditions.

The likelihood of a respondent in the No Group to place a CE on their property increased under the following conditions: if they were offered 1) a property tax benefit, 2) an estate tax benefit, 3) an income tax benefit, 4) 
property rights assurances to guarantee no additional regulatory burdens would arise as a result of the $C E$ or 5 ) paid the value of the $C E$. Under these conditions, approximately $25 \%$ of respondents in the No Group, shifted to Likely or Very Likely, while a little more than $25 \%$ shifted to Neither Likely nor Unlikely.

Under these same five conditions, more than $50 \%$ of respondents in the Maybe Group, shifted to Very Likely or Likely, while a little less than $50 \%$ remained Neither Likely nor Unlikely. Over $50 \%$ of the Yes Group maintained a Very Likely or Likely response even if there was no benefit associated with the CE or if they were asked to make a donation to the land trust for the management of the $\mathrm{CE}$.
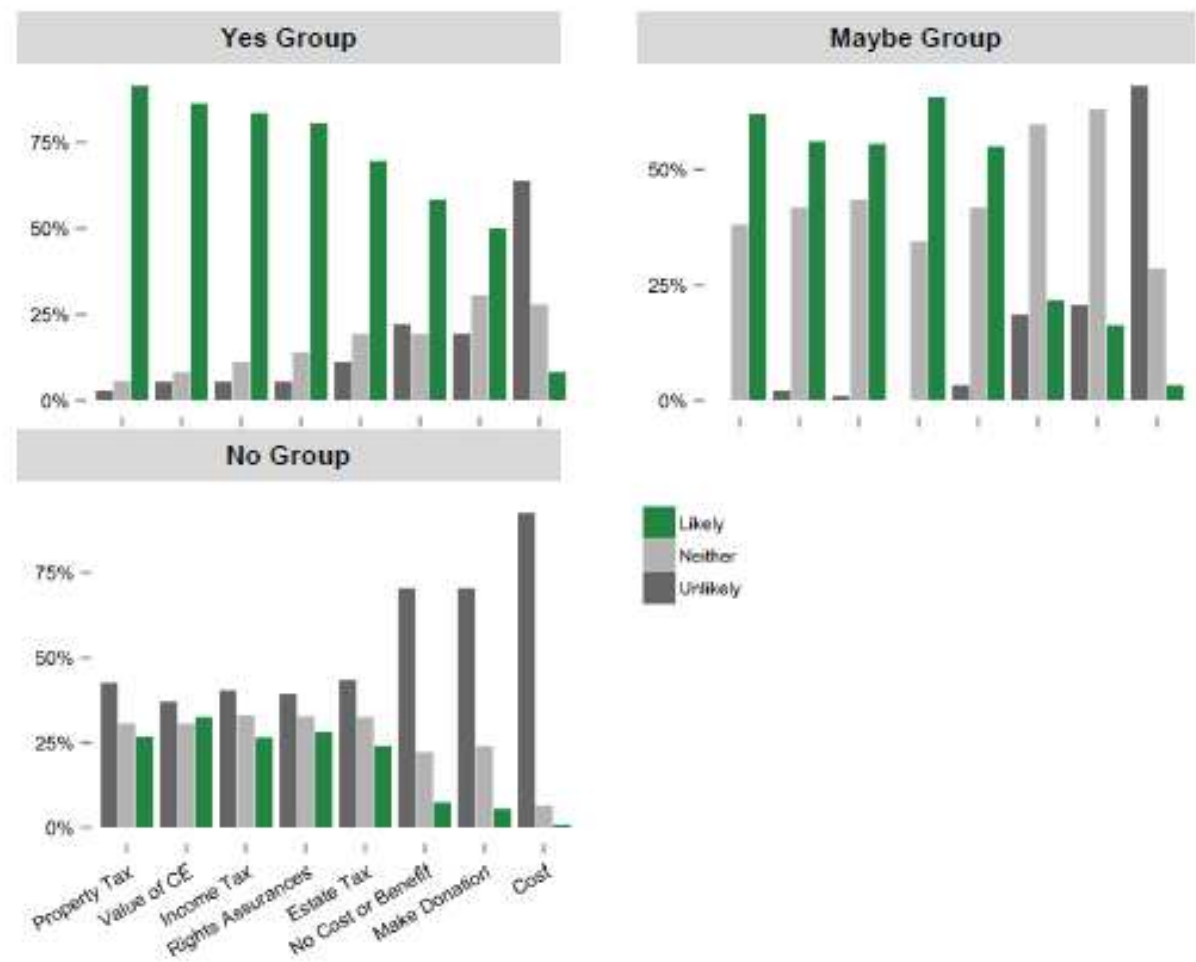

Figure 6.4 [Q14] Cost and Benefit: compares respondents in the Yes ( $n=43)$, Maybe ( $n=95$ ) and No (n=119) group based on their responses to Q14 


\section{Place Connections}

Q21 was meant to assess respondents ${ }^{t}$ connection to the Watershed. The sense of place literature highlights the link between a strong positive sense of place and place protection behavior (Cross et al. 2011, Vaske and Kobrin 2010). Therefore, I was interested in the differences between the three groups in terms of their connection to the Whychus Creek Watershed. Figure 6.5 [Q21] compares the Yes, No and Maybe Groups based on their responses to Q21. Refer to Section Five or Appendix B for the full item descriptions.

\section{Key Findings}

Most respondents in the Yes Group agreed with the place statements. About $50 \%$ of the respondents in the Maybe Group agreed with the place statements, whereas on average less than $50 \%$ of the No Group agreed with the statements. More respondents in the Maybe and No Groups marked Neither Agree nor Disagree compared to respondents in the Yes Group. This comparison suggests that sense of place may be associated with interest in CEs.

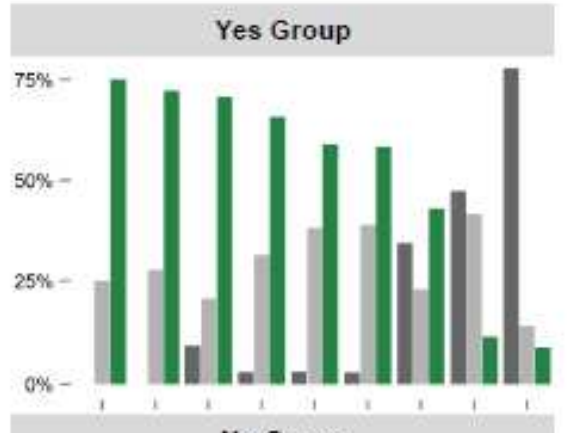

No Group

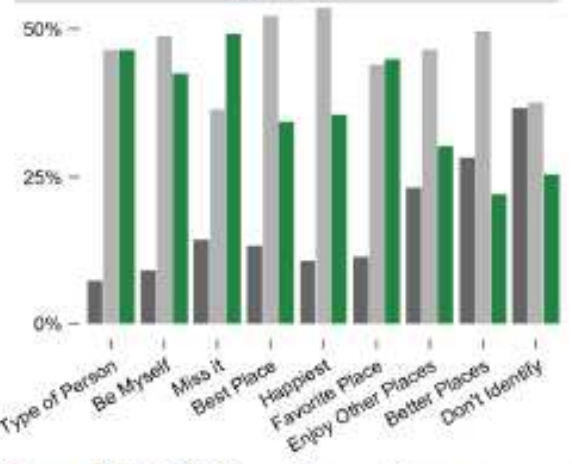

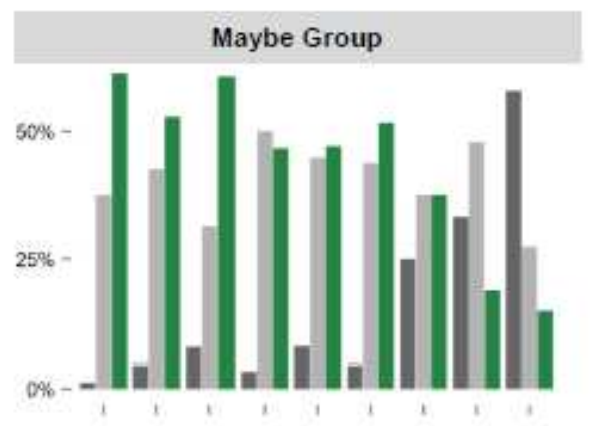

Agree Neither Disagree

Figure 6.5 [Q21] Place Connections: compares respondents in the Yes ( $n=43)$, Maybe $(n=95)$ and No ( $n=119$ ) group based on their responses to Q21 
Brown, D. G., Johnson, K. M. Loveland, T. R. and D. M. Theobald. 2005. Rural Land-Use Trends in the Conterminous United States, 1950-2000. Ecological Applications 15:1851-1863.

Butler, Brett J. 2008. Family Forest Owners of the United States, 2006. Gen. Tech. Rep. NRS-27. Newtown Square, PA: U.S. Department of Agriculture, Forest Service, Northern Research Station. $72 p$.

Cross, J., Keske, C., Lacy, M., Hoag, D., Bastian, C. 2011. Adoption of conservation easements among agricultural landowners in Colorado and Wyoming: the role of economic dependence and sense of place. Landscape and Urban Planning 101: 75-83.

Diliman, D. 2000. Mail and Internet Surveys: The Tailored Design Method. John Wiley and Sons, inc., New York, NY.

Jorgensen, B., Stedman, R. 2001. Sense of place as an attitude: Lakeshore owners attitudes toward their properties. Journal of Environmental Psychology 21: $233-248$,

Kiesecker, J.M. et al. 2007. Conservation easements in context: a quantitative analysis of their use by The Nature Conservancy. Frontiers in Ecology 5: 125-130.

Maestas, J., Knight, R., Gilgert, W. 2001. Biodiversity and Land-Use Change in the American Mountain West. Geographical Review 91: 509-524

Peterson, N., Speer, D., McMillan, D. 2008. Validation of a brief sense of community scale: confirmation of the principal sense of community. Journal of Community Psychology 36: 61-73.

Scott, J. M., F. W. Davis, R. G. Mcghie, R. G. Wright, J. Estes, I. F. W. Davis, and C. Groves. 2001. Nature Reserves: Do They Capture the Full Range of America's Biological Diversity? Ecological Applications 11:9991007 .

U.S. Census Bureau. 2009-2013 5-Year American Community Survey.

Vaske, J., Kobrin, K. 2010. Place attachment and environmentally responsible behavior. The Journal of Environmental Education 32: 16-21. 


\section{APPENDIX C. Human Subjects Approval}

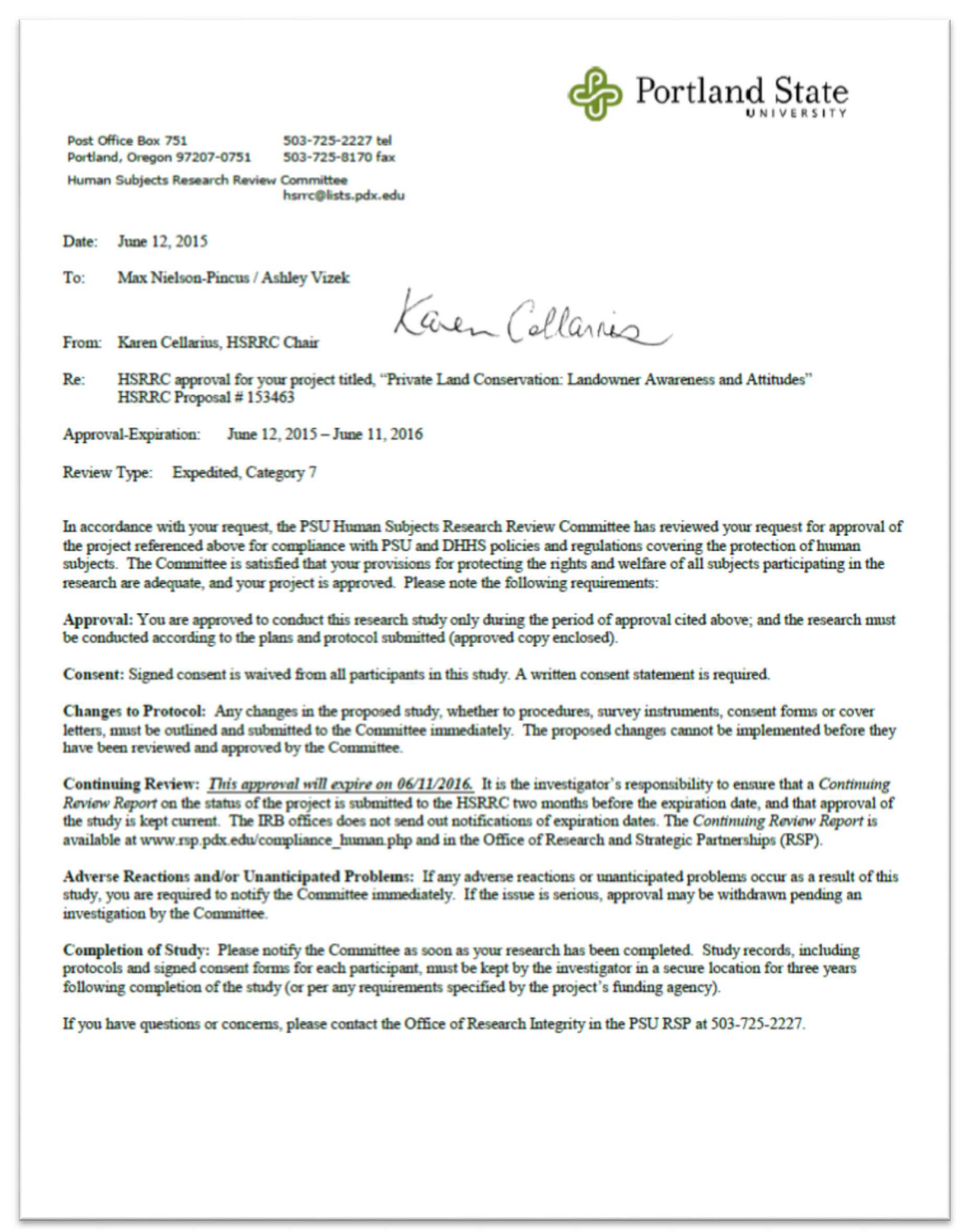

